\title{
A MUTANT WITH APETALOUS FLOWERS IN OILSEED RAPE (BRASSICA NAPUS): MODE OF INHERITANCE AND INFLUENCE ON CROP PHYSIOLOGY AND SCLEROTINIA INFECTION
}

Doctoral Dissertation

Submitted for the Degree of Doctor Agricultural Sciences at the Faculty of Agricultural Sciences of Georg-August-University Göttingen

\author{
by \\ Lixi Jiang \\ from Zhejiang, China
}

Göttingen, February 2001 
Jiang, Lixi:

A mutant with apetalous flowers in oilseed rape (Brassica napus):

Mode of inheritance and influence on crop physiology and Sclerotinia infection

D7

Referent

Prof. Dr. H. C. Becker

Korreferent

Prof. Dr. R. Rauber

Tag der mündlichen Prüfung: 15.2.2001 
For my dear parents and Weiping \& Bepe 


\section{CONTENT}

1 Introduction 1

2 Literature review 5

$3 \quad$ Materials and methods $\quad 18$

$4 \quad$ Results and discussion $\quad 24$

4.1 Inheritance of the apetalous character in 'ap-Tengbe' and environmental effects on expression of apetalous flowers 24

4.2 Influence of apetalous flowers on crop physiology and $\begin{array}{ll}\text { Sclerotinia infection } & 27\end{array}$

4.3 Conclusions 31

$5 \quad$ Summary 33

$6 \quad$ References $\quad 35$

$7 \quad$ Separate manuscripts

7.1 Jiang L. and H. C. Becker: Inheritance of a mutant with apetalous flowers in oilseed rape (Brassica napus) 46

7.2 Jiang L. and H. C. Becker: Environmental effects on expression of apetalous flowers in oilseed rape (Brassica napus). J. Appl. Botany. In press

7.3 Jiang L. and H. C. Becker: Effect of apetalous flowers on crop physiology in winter oilseed rape (Brassica napus).

Pflanzenbauwissenschaften. In press

7.4 Jiang L., H. C. Becker, Q. Zhao, G. Wolf: Influence of apetalous flowers on infection of Sclerotinia sclerotiorum in oilseed rape (Brassica napus)

List of tables and figures

Frequently used abbreviations 


\section{INTRODUCTION}

Rapeseed oil is produced from different oil-yielding Brassica species, e.g. Brassica napus, Brassica rapa and Brassica juncea, with a yearly world production of about $3.60 \times 10^{7}$ million ton. It is the third most important oilseed worldwide after soybean and cottonseed. The total production and grown acreage of rapeseed increased continuously and remarkably in recent years, contrasting to that of cottonseed and soybean (Table 1-1) (FAO production yearbook 1996-1999). This tendency of expansion for rapeseed production started some decades ago due to the substantial improvement of fatty acids composition and meal quality firstly in Canada and Europe and then worldwide (Downey et al. 1975, Röbbelen 1997). Nowadays, rapeseed oil is one of the most nutritionally desirable edible oils.

A considerable proportion of the increment of the world production of rapeseed has been contributed by developing countries, in particular China and India (FAO yearbook 1990-1999). On the way towards industrialization, developing countries are confronted with increasing population and the corresponding demand for agricultural products, which is limited by decline of arable land and by enlarging recognition of the burden imposing on natural ecosystem aroused by intensive agricultural land uses. In this background, genetic improvement of crops is an effective way to increase production without additional external inputs by a more efficient transformation of solar energy and internal regulation of metabolic functions.

Different strategies have been applied to elevate grain yield (Becker 1993, Becker et al.1999). One of the effective approaches is to seek morphologically ideal types (ideotype). Some morphological traits, such as short and strong stalk, erect leaf posture, splitting leaf shape, dark green leaf color, waxed leaf surface, big seed, large number of seeds, are of common interest in crop breeding for high grain yield. In rapeseed, apart from the above features, apetalous flower morphology is also very interesting, as rapeseed plant has a mass of brightly colored flowers at the top layer for an extended period. Apetalous genotypes may have the following advantages: 
Table 1-1 Worldwide production of the most important oilseeds (1996-1999)

\begin{tabular}{llcccc}
\hline & & \multicolumn{3}{c}{ Production } & \multicolumn{3}{c}{ Acreage } \\
\cline { 3 - 5 } Rapeseed & & $10^{7} \times \mathrm{Mt}$ & $\pm \%$ & $10^{7} \times \mathrm{Ha}$ & $\pm \%$ \\
& 1996 & 3,05 & - & 2,18 & - \\
& 1997 & 3,52 & 15,41 & 2,36 & 8,26 \\
& 1998 & 3,59 & 1,99 & 2,60 & 10,17 \\
\multirow{5}{*}{ Seed cotton } & 1999 & 4,25 & 18,38 & 2,76 & 6,15 \\
& Mean & 3,60 & 11,93 & 2,47 & 8,19 \\
& 1996 & 5,49 & - & 3,45 & - \\
& 1997 & 5,44 & $-0,91$ & 3,38 & $-1,78$ \\
& 1998 & 5,16 & $-5,15$ & 3,32 & 0,00 \\
& 1999 & 5,21 & 0,97 & 3,32 & $-1,27$ \\
& Mean & 5,33 & $-1,70$ & 3,37 & 8,93 \\
& 1996 & 13,07 & - & 6,16 & 5,07 \\
& 1997 & 14,45 & 10,56 & 6,71 & 1,84 \\
& 1998 & 15,98 & 10,59 & 7,05 & 5,28 \\
\hline
\end{tabular}

(Source: FAO on line statistics, http://www.fao.org/) 
1. Achievement of more efficient photosynthesis due to the absence of yellow flower layer, which is about 50-70 cm thick at peak flowering and forms a surface effectively reflecting and absorbing solar irradiation. The top layer of rapeseed reflects or absorbs nearly $60 \%$ of incoming solar irradiation (Mendham et al. 1981) and only 24,7 and $6 \%$ of photosynthetically active radiation (PAR) reach to base of inflorescence at early flowering, late flowering and pod filling stages, respectively (Chapman 1984). The reflected and absorbed radiation may be otherwise utilized by leaves and siliques.

2. Saving of photosynthesized assimilates used for the formation and the respiration of petals. The saved assimilates may flow to and benefit the other floral parts, in particular, the green calyx, androecium and gynoecium (Lü \& Fu 1990).

3. Less evaporation and higher root activity, which could be beneficial to yield especially in drought environment. Apetalous types maintain a consistently higher stomatal conductance, but also a higher leaf turgor at lower osmotic potentials (Mendham 1991).

4. Probable avoidance of some diseases. It was discovered that more than 50 groups of ascospores exist on rape petals, among which some are aggressive (Lefol \& Morrall 1999). Petals not only favor infection by serving as $\mathrm{C}$-source that is needed by invading fungus, but also as infection sites when they wilt and drop on other parts of a plant (Mc Lean 1958, Krüger 1975, Larmaque 1983). The ascospores of some diseases, e.g. Sclerotinia sclerotiorum, do not germinate when they land directly on leaf surface (Jamaux 1995, 1999).

On the other hand, some negative influence might occur, provided that apetalous character is introgressed into commercial cultivars. First of all, rapeseed production, particularly hybrid seed production, depends on pollinating insects, primarily honeybees. Morphological modifications of the flower could lead to less attractiveness to honeybees and influence the foraging behaviors of the insects. Apetalous character may induce pleiotropic effects on pollen and nectar production, flavor or any potentially attractive 
factors (Renard \& Mesquida 1987, Pierre et al. 1996). Secondly, rapeseed may be grown, at least in some places, e.g. in Schleswig-Holstein of northern Germany, not only as oil source, but also for tourism purpose, as a landscape with bright golden yellow rape flowers stretching to horizon is a beautiful scenery attracting urban tourists.

Notwithstanding these negative prospects, apetalous character is interesting to plant breeders and worth studying for its potential in elevating yield.

Apetalous genotypes have different origins. Most of them were either discovered in nature, further stabilized by inbreeding (Singh 1961a \& 1961b; Buzza 1983; Lü \& Fu 1990), or created by crossing between related species and then improved for agronomic traits by backcrossing with the elite parent (Chen 1989, Malik et al. 1999). The apetalous mutant 'ap-Tengbe' studied in our experiments was induced with EMS-treatment at Institute of Agronomy and Plant Breeding, Georg-August-University Göttingen (Tengbe 1990). It has not been characterized in details so far and we are interested in its following aspects.

1. Genetics:

(1) To understand inheritance of the mutant 'ap-Tengbe' with apetalous flowers in oilseed rape (Brassica napus) $(\rightarrow 7.1)$, and

(2) To investigate environmental affects, in particular plant hormones, on expression of apetalous flowers in oilseed rape (Brassica napus) $(\rightarrow 7.2)$.

2. Physiology:

To investigate the influence of apetalous flowers on crop physiology in winter oilseed rape (Brassica napus) in the field experiment grown at different plant densities and nitrogen levels $(\rightarrow 7.3)$.

3. Pathology:

To investigate the influence of apetalous flowers on the infection from Sclerotinia sclerotiorum in oilseed rape (Brassica napus); and find out practical method in quantitatively determining infection degree of Sclerotinia disease $(\rightarrow 7.4)$.

The results obtained from the above investigation were discussed in comparison with the results of some previous studies in literature (4.1 \& 4.2). 


\section{LITERATURE REVIEW}

\section{Morphological description of the typical flowers in oilseed rape}

Normal flowers of oilseed rape are yellow, widely spread and attractive to insects when open. They are regular and cruciform, bisexual, complete and hypogenous. The calyx has 4 unattached sepals in two whorls. The corolla consists of 4 free petals in one whorl, each with distinct limb and claw. The androecium consists of 6 stamens in two whorls, the outer two of which are shorter than the inner (tetradynamous). The ovary is superior, at first one celled but subsequently 2-celled because of the development of a false septum (Murphy 1994).

Among the floral organs, petals take the greatest proportion of weight. Considerable photosynthesized assimilates are consumed for petal formation and respiration (Lü \& Fu 1990).

Rapeseed flowers appear very bright to eye during flowering, indicating a high reflection of the visible spectrum.

\section{Discovery of apetalous character and studies on the inheritance}

As described above, four in cross form arranged petals are one of the distinct floral characteristics in the family Brassicaceae. Apetalous trait is a kind of floral abnormality, which was firstly reported in India in 1945 (species not clear). The character was reportedly due to a single recessive gene subject to the influence of modifiers (The Imperial Agricultural Research Institute New Delhi 1945).

Many years later, mutants with apetalous flowers were discovered in Brassica rapa (Singh 1961a, 1961b, Cours \& Williams 1977). The segregation in the F2 progenies from crosses between apetalous and normal parents exhibited a 3: 1 (normal to apetalous) ratio, suggesting that the apetalous trait in Brassica rapa was controlled by one recessive gene. Apart from the segregation ratio, Singh (1961a) also observed that the apetalous trait in his mutant was associated with a reduction in the number of stamens, yet the pod and seed were normal.

An apetalous variant was created by remote crossing between Brassica napus and Brassica rapa (Brassica napus as maternal parent) during 
1975-1980 at Huazhong Agricultural University at Wuhan, China. The apetalous line was crossed with a normal cultivar. The F1 plants had normal petalled flowers, yet in the F2 generation the petalous degree (PDgr) segregated very complicatedly. No hypothesis for the inheritance was given based on his observation (Liu 1985).

An apetalous variant in Canola (rapeseed with seed quality of low erucic acid (erucic acid $<2 \%$ ) and low glucosinolates content (glucosinolates content $<30 \mu \mathrm{mol} / \mathrm{g}$ )) was reported in Australia (Buzza 1983). The flowers of the Australian apetalous line were normal except for absence of petals. The anthers were slightly shorter than many varieties but still well in the range found in Canola varieties. To determine the inheritance of the apetalous character, Buzza crossed the apetalous line reciprocally to a normal line 'RU6' and observed the F1 and F2 generations. Backcrosses of the F1 to both parents were made too. As no differences between reciprocal crosses were observed, it was concluded that the two parental lines had the same cytoplasm. Moreover, it was revealed that the apetalous flowers were controlled by two recessive genes. A normal plant would have four alleles for petals (PPPP) and the apetalous plant would have four alleles for absence of petals (pppp), $P$ was dominat to $p$.

An apetalous mutant in Ethiopian mustard (Brassica carinata A. Braun) was studied at University of California, Davis, USA. Reciprocal crossings between apetalous and normal parents were made. The F1 or RF1 plants were found all similar to normal parent. It was concluded accordingly that cytoplasmic effect was absent and dominant gene action presented. Two major genes were found governing the petalous degree. It was hypothesized that the ancestral species of Brassica carinata, Brassica. nigra and Brassica oleracea, each contributed a gene that governed petally (Rana 1985).

By re-synthesizing Brassica napus from Brassica rapa and Brassica oleracea, an apetalous line was created at Swedish University of Agricultural Sciences. The original efforts of the Swedish study was aiming at yellow seeded genotypes, which have thinner seed coat associating with higher oil and protein, and lower crude fiber contents in comparison to black or brown seeds (Shirzadegan \& Röbbelen 1985, Chen \& Heneen 1990). The apetalous 
plants were completely petalless at early flowering stage but had one or two petals on some flowers at later stages. The genetic regulation of the apetalous trait was not investigated (Chen et al. 1988, Chen 1989).

Another apetalous variant in Brassica napus was bred in Jiangsu Academy of Agricultural Sciences at Nanjing, China. It was suggested that four recessive genes control the inheritance of the apetalous trait. Lü \& Fu (1990) crossed their apetalous line - 'APL 0256' with 7 normal petalled genotypes, which had different petal sizes. They observed and scored the apetalous degree in the F2 and $\mathrm{BC} 1$ generations. The segregations of apetalous trait in the $\mathrm{F} 2$ and $\mathrm{BC} 1$ were different for different crosses, ranging from 255: 1 to 16:1 in the F2 or 16:1 to $4: 1$ in the $\mathrm{BC} 1$ for normal petalled to apetalous flowers. The explanation was that the petals of small size, e.g. in genotype as 'MI-CMS', were coded by $P_{1} P_{1} P_{2} P_{2} p_{3} p_{3} p_{4} p_{4}$. In such cases, normal petalled genotypes were controlled by two pairs of dominant genes. The other two pairs recessive genes remained homozygous in all other generations. However, the bigger petals, e.g. in some Chinese materials as 'DL', '75011', 'Rongshan', 'DN-1792', 'RL-4003', 'Zaxuan-841', were coded by $P_{1} P_{1} P_{2} P_{2} P_{3} P_{3} P_{4} P_{4}$. In such cases, normal petalled genotypes were controlled by four pairs of dominant genes. Therefore, when apetalous genotype $\left(p_{1} p_{1} p_{2} p_{2} p_{3} p_{3} p_{4} p_{4}\right)$ crossed with the genotypes with small petals $\left(P_{1} P_{1} P_{2} P_{2} p_{3} p_{3} p_{4} p_{4}\right)$, the segregation of plants with normal flowers to plants with apetalous flowers in F2 and BC1 was 15:1 and 3:1, whilst when crossed with genotypes with big petals $\left(P_{1} P_{1} P_{2} P_{2} P_{3} P_{3} P_{4} P_{4}\right)$, the segregation in F2 or BC1 turned out to be $255: 1$ or 15:1, respectively.

To map genes that control flower morphology in three distinct apetalous variants (Brassica napus), RFLP analysis was applied at Jon Innes Center in UK. It was found that one apetalous phenotype was determined by an epistatic interaction between recessive alleles at a pair of homoeologous loci. Another apetalous type was controlled by an interaction between alleles at three loci (Kelly et al. 1995).

Also in UK, an apetalous line 'N-o-11' with shriveled leaves was studied. Genetic analysis demonstrated the cosegregation of genes controlling both morphologies. Two STAP (stamenoid petal) loci controlling the production of flowers with stamenoid petals were mapped to homoeologous loci in the 
genome of Brassica napus. It was suggested that the STAP loci were probably duplicated genes because they exhibited an epistatic interaction such that only plants homozygous for recessive stap alleles at both loci expressed the variant phenotype. The CURLY LEAF (CLF) gene of Arabidopsis thaliana pleiotropically influences both flower and leaf morphologies. The cloned CLF gene of Arabidopsis thaliana was homologous to a polymorphic Brassica napus coincident with one of the Brassica napus STAP loci. The possibility that CLF was a candidate gene for STAP suggested that the variant stap alleles of Brassica napus exert pleiotropic effects over both flower and leaf morphologies (Fray et al. 1997).

More recently, some apetalous lines were produced in Brassica juncea by bridgecross. Cytoplasmic male sterility (CMS) was found associated with apetalous trait (Malik et al. 1999).

Different apetalous sources and the inheritance of apetalous trait in these sources are summarized in Table 2-1.

Apetalous trait is also present in other crops. Eliseev (1979), Ponomarenko (1980) and Tobutt (1994) reported apetalous flowers in apple and that the inheritance was controlled by one recessive gene. The apetalous plants exhibited abnormal flower behavior, i.e. most of the apetalous plants did not set fruit only after controlled pollination with foreign pollen or set fruit parthenocarpically or apomictically. Sorochinskaya \& Galkin (1972) described a linseed plant without a corolla. In cucumber, Grimbly (1980) found an apetalous mutant that was controlled by one single recessive gene. 
Table 2-1 Different apetalous sources in oilseed Brassicas and the inheritance of the apetalous trait in these sources

\begin{tabular}{|c|c|c|}
\hline Sources & Species & Genetic control of apetalous trait \\
\hline Singh 1961 & B.rapa & $\begin{array}{l}\text { Controlled by one recessive gene; apetalous: } \\
\text { normal petalled }=1: 3 \text { in } \mathrm{F} 2\end{array}$ \\
\hline $\begin{array}{l}\text { Cours \& } \\
\text { Williams } \\
1977\end{array}$ & B. rapa & $\begin{array}{l}\text { Controlled by one recessive gene; apetalous: } \\
\text { normal petalled }=1: 3 \text { in } \mathrm{F} 2\end{array}$ \\
\hline Buzza 1983 & B. napus & $\begin{array}{l}\text { Controlled by two recessive genes; apetalous: } \\
\text { intermediate type: normal=1:14:1 }\end{array}$ \\
\hline Liu 1985 & B. napus & Not clear \\
\hline Rana 1985 & B. carinata & $\begin{array}{l}\text { Controlled by two recessive genes, modified by } \\
\text { number of unidentified genes; intermediate types } \\
\text { in F2 sensitive to environmental factors }\end{array}$ \\
\hline Chen 1989 & B. napus & Not clear \\
\hline Lü \& Fu 1990 & B. napus & $\begin{array}{l}\text { Controlled by four recessive genes, whether } 1: 255 \\
\text { or } 1: 15 \text { for segregation ratio of apetalous:normal in } \\
\text { F2 population depending on the size of the petal of } \\
\text { the normal parent }\end{array}$ \\
\hline $\begin{array}{l}\text { Kelly at el } \\
1995\end{array}$ & B. napus & $\begin{array}{l}\text { Determined by an epistatic interaction between } \\
\text { recessive alleles at a pair of homologous loci }\end{array}$ \\
\hline $\begin{array}{l}\text { Kelly at el } \\
1995\end{array}$ & B. napus & $\begin{array}{l}\text { Controlled by interaction between alleles at three } \\
\text { loci. }\end{array}$ \\
\hline $\begin{array}{l}\text { Fray et al. } \\
1997\end{array}$ & B. napus & $\begin{array}{l}\text { Controlled by an epistatic interaction between two } \\
\text { loci, with segregation distortion at one or both loci } \\
\text { resulting in a reduced frequency for the recessive } \\
\text { alleles which promoted the apetalous phenotype }\end{array}$ \\
\hline $\begin{array}{l}\text { Malik et al. } \\
1999\end{array}$ & B. juncea & $\begin{array}{l}\text { Apetalous trait associated with cytoplasmic male } \\
\text { sterility }(C M S) \text {. No information on the segregation } \\
\text { patterns. }\end{array}$ \\
\hline
\end{tabular}




\section{Changes of apetalous degree in environment and effect of hormones on development of floral organs}

The apetalous character in rapeseed was found unstable, or easily affected by environmental conditions. More complete apetalous degree was observed at later flowering stage than at initial anthesis in different apetalous materials (Liu 1985, Tengbe 1990). In contrast to this phenomenon, some authors observed a more complete apetalous degree in earlier flowering stage rather than in later stage (Rana1985, Chen1989). By scanning electron and light microscopy on developing buds of petalous and apetalous flowers, it was found that the sequence of floral development was sepals, androecium and gynoecium simultaneously, and lastly the corolla. The development of apetalous and petalous types was similar until corolla initiation, and petal development appeared to be in delicate balance with the internal and external environment (Rana 1985).

Balance of endogenous plant hormones may be important in the process of floral organ initiation and differentiation. Such hormones may likely be cytokinins and auxins (Davies 1987, Metzger 1987). Cytokinin concentrations were found higher in early floral initiation and development stages in comparison to the vegetative stage in tuberose corms (Polianthes tuberosa) (Chang 1999). The involvement of cytokinins in floral organ development were also studied and described in Dianthus chinensisi L. (Zhou et al. 1995), in tomato (Lycopersicon esculentum) (Menary \& Staden 1976, Kaur et al. 1996), in Hyacinthus orientalis (Lu et al. 1994), and in Chenopodium rubrum (Vondrakova et al. 1998). Auxins' significant activities in differentiation and the formation of floral meristem were discovered in the early growth stage in Arabidopsis thaliana L. (Oka et al. 1999), and in Bougainvillea glabra L. (Awad et al. 1988), and in Tanacetum cinerariaefolium L. (Brown \& Menary 1994). Some other hormones or substances may also have influence on floral organ formation. These are lipid (Hobbs et al. 1996), gibberellin (Okuda \& Fujime 1999), phosphorus (Menary \& Staden 1976).

Thus, application of exogenous hormones may disturb endogenous balance of plant hormones and impose influence on the process of floral organs 
development. Venglat et al. (1996) used Arabidopsis thaliana L. Heynh. as a model crop to investigate the regulatory genes that control and coordinate the determination, differentiation and morphogenesis of the floral meristem and floral organs. It was revealed that application of BAP, a cytokinin, to inflorescences at certain developmental stages resulted in: (1) increase in floral organ number; (2) formation of abnormal floral organs and (3) induction of secondary floral buds in the axils of sepals. It was suggested that exogenous BAP suppresses the normal function of the genes for floral meristem identity and thereby affects flower development and the later stages of floral organ differentiation.

\section{Other floral abnormalities and inheritance of floral characters}

In addition to apetalous character, some other flower abnormalities were reported in Brassicas and other genera. Singh (1961a) noted a plant in his inbred lines of brown sarson with flowers of $4,5,6$ petals. The abnormal numbers resulted from splitting of the petals. Palmer (1958) also reported split petals in some flowers of $B$. napus, B. oleracea, $R$. sativa and $M$. biocornis.

Apart from petal number, the inheritances of other flower related traits in oilseed Brassicas are reviewed as the following:

Anther condition (Brassica rapa): Controlled by single pair of genes, extrose: introse $=3: 1$ in F2 (Ali Mohammed \& Sikka 1937)

Petal color (Brassica rapa): Controlled by single pair of genes, yellow: white $=$ 3:1 in F2 (Richiharia 1957)

Petal color (Brassica carinata): The yellow flower color was governed by two complementary dominant genes (Heyn 1973); Controlled by single pair of genes, cream: yellow = 3:1 in F2 (Getinet et al 1993)

Petal color (Brassica juncea): Controlled by two loci, yellow: pale yellow: white = 12: 3: 1 in F2 (Singh et al 1964; Rawat \& Anand 1986; Brar et al 1991)

Petal color (Brassica juncea): Governed by 2 dominant genes, $\mathrm{Y}$ and $\mathrm{Cr}$, that interacted epistatically, $Y$ present either single or doubly, resulted in normal yellow flowers and was epistatic to $\mathrm{Cr}$ that codes cream flowers, the double recessive genotype (yy crcr) bore white flowers (Rawat et al 1986); Controlled 
by single pair of genes, yellow: white $=3: 1$ in $\mathrm{F} 2$ (Brar et al 1991)

Petal color (Brassica napus): Controlled by three pairs of genes, AB for yellow, $A b$ for dark orange yellow; ab for pale orange yellow, $c$ accounts for cream white. B locus is inactive in presence of aa and cc (Morice 1960); Monogenically controlled by gene on C-genome, yellow: termediate: white $=12: 3: 1$ in F2 (Chen 1990); Controlled by single pair of genes, lemon yellow: pale yellow = 3:1 in F2 (Seguin-Swartz 1988)

Petal shape (Brassica rapa): Controlled by single pair of genes, normal: tucked = 3:1 in F2, normal: jagged-petal margin = 3:1 in F2 (Hawk \& Crowder 1978) Petal shape (Brassica nigra L.): The folded petal trait was thought to be controlled by two luci (Delwiche \& Williams 1977)

\section{Apetalous trait as a component of an ideotype in breeding towards high yield}

Yield improvement has always been an important object for plant breeders, although since middle sixties, improving quality of oil and meal in Brassica oilseeds is more and more important (Downey \& Rakow 1987; Röbbelen 1997). In long term, yield must be sought to ensure that farmers have the greatest returns in production. In developing countries, where the requirement for elementary daily nutrients has not yet been met, high yielding is always the most important object, for which the breeders are striving.

Yield is a typical quantitative trait, controlled by many additive genes and influenced heavily by environmental factors. Under given husbandry practice or ecosystem, genetic properties such as maturity, resistance to lodging and shattering, resistance to weeds, insects and in particular to the major diseases (Phoma lingam, Leptosphaeria maculans, Sclerotinia sclerotiorum, Verticillium dahliae, virus disease as TuMV, CMV, etc.) are limiting factors for high yield in oilseed rape. Various breeding strategies are adopted to maximize the yield (Oosterom \& Acevedo 1992, Becker 1993, Bentota et al.1998, Becker et al. 1999).

Seeking for ideotype is one of the effective strategies and sought by breeders in a range of field crops (Fray et al. 1996, Habekotte 1997). By breeding practice, many morphological and agronomic traits are utilized as 
parameters assisting the selection for ideal morphological type (ideotype) towards high yield. Certain common desirable features are known as i.e. short strong stems, good performance at high plant population density, an efficient canopy of leaves, economic response to fertilization and high harvest index. Plant breeders are consciously or unconsciously selecting plants combining all advantageous morphological features. There is no exception for oilseed rape. Reports can be found in literature regarding the selection for favorite traits such as long pods (Singh 1974; Chay \& Thurling 1989), erect pod (Alam \& Muhammad 1953, Nayar \& George 1970; Rao \& Mendham 1991, Fray et al. 1996), efficient seed survival (McVetty et al 1989; Mendham et al. 1991), high 1000-seed weight (Olsson 1960), yellow seed coat (Jönsson 1975; Vera et al. 1979; Dohhon et al 1982; Shirzadegan \& Röbbelen 1985; Zaman 1989), waxed leaf surface (Mo et al. 1992, 1995), splitting leaf shape (Geltink 1983), erect leaf posture (Austin et al 1976), short stalk (Hawk \& Crowder 1978), resistance to shattering (Kadkol 1987), etc.

Apart from the above features, apetalous flower is very interesting, as rapeseed has particular problems in producing a photosynthetically efficient canopy because of the brightly colored flowers at the top layer for an extended period. It was observed that flowers were present over a period of approximately 6 weeks in typical cultivars of European winter rapeseed. A linear relationship was found between flower cover (maximum 74\%) and photon reflectivity $(400-700 \mathrm{~nm})$ that increased from 0,047 during vegetative growth to 0,195 for a canopy in full flower. That leads to the reduction of light availability to the leaf canopy and immature pods. It was measured that flowering canopies reflect substantially more radiation and absorb less than vegetative canopies between PAR (photosynthesizing active radiation) of 500 and $700 \mathrm{~nm}$ but reflect less and absorb slightly more between PAR of 400 and $500 \mathrm{~nm}$ (Yates et al. 1987). Moreover, most leaves senesced soon after flowering commenced and green pods and stems became the major sources of photosynthesis (Mendham et al. 1991). It was concluded that despite of the increased pods per plant due to increased flower density, the agronomic potential was compromised by the increased reflectivity by petals. Breeding for genotypes with reduced petal size or without petals was suggested for a more 
efficient light distribution within the canopy for oilseed rape.

Such genotype in canola was developed in Australia (Buzza 1983) and was compared for its physiological significance with 'Marnoo', a cultivar bearing conventional yellow petals (Rao et al. 1991). It was found that apetalous flowers allowed $30 \%$ more short wave radiation to reach the base of the inflorescence, and reflected only half as much radiation as 'Marnoo' at peak flowering. Therefore, leaves persisted and remained active longer. It also resulted in more seeds per pod and heavier seed weight at all height within the canopy, and consequently, higher yield. At very high population density, the apetalous line retained productive secondary branches, whereas 'Marnoo' had none. The yield of the apetalous line retained high even without irrigation, in contrasting to much lower yield of 'Marnoo' under such condition (Rao et al 1991).

However, it was concerned that changes in floral morphology, i.e. removed petals, may influence the foraging behavior of honeybee and lead to less cross-pollination (Renard \& Mesquida). Apetalous and normal petalled genotypes were compared in this respect (Pierre et al. 1996). Number of flowers $/ \mathrm{m}^{2}$ and nectar volumes, which are considered as important attractive factors, did not differ between the tested genotypes. Honeybee density was found even significantly higher on the apetalous type when their foraging activity was rather high. Honeybees showed a considerable constancy to each flower type. However, nectar foraging behavior differed with the floral morphology. On the normal flowers, honeybees visited the two inner nectaries by crawling over the anthers and the stigma, while on the apetalous ones they often inserted their tongues between the sepals, thus having less contact with the reproductive organs. It was concluded that apetalous type had more attractiveness to honeybees but lower efficiency of cross-pollination.

\section{Sclerotinia disease in rapeseed and petals' role in the infection}

The infection of Sclerotinia sclerotiorum disease is reported in most areas important for rapeseed production (Paul 1991, Fang \& Platford 1994, Thomson et al.1994). The symptom of the disease is normally apparent after flowering stage. Typically, white or light yellow canker appears on stalk or on branches near the joint position of major stem and branches. On the surface of the canker, 
white mycelium is detectable, and in the center of the canker, it is gray. The branches and pods above the infected position become yellow to brown, indicating unnatural maturity. The stems become hollow and light gray, later black, irregular formed sclerotias are developing inside.

Figure 2-1 shows the life cycle of Sclerotinia sclerotiorum (Hoffmann \& Schmutterer 1983, Jellis et al. 1984, Heitefuss et al. 1987). The sclerotia fall to the soil after threshing or directly from the infected stalk. They keep alive in soil within 7-10 years. The mycelium develops and spreads only at the top layer $(0-5 \mathrm{~cm})$ of the soil, and they directly infect young plants in mild autumn and winter. Under suitable temperature and humidity, the sclerotias sprout and apothecias grow up. The ascospores are spread by wind and carried onto rapeseed plants. Petals play an important role in the infection of Sclerotinia disease. First, they favored the infection by serving as C-source that is needed by the invading fungus (Krüger 1975). Second, petals that covered with mycelium are the infection sites, where the mycelium invades leaf tissues further. The ascospores that land directly on leaf surface do not germinate (Mc Lean 1958, Larmarque 1983). On young petals, adhesion, germination, penetration of ascospores and the collapse of epidermal cells were observed by scanning electron microscopy (Jamaux 1994, 1999).

Once a plant gets infected by pathogens, a range of enzymes degrading plant cell wall are excreted in epidermal cells with extra amount. These hydrolysates may correlate to the infection degree (Cooper \& Wood 1975, Bateman \& Basham 1976, Perez \& Tena 1990). Techniques have been developed for quantitative analysis (Wirth \& Wolf 1990, Afshari-Azad 1992).

Genotypes that are immune or highly resistant to Sclerotinia disease were hardly found in the existing germplasm of oilseed rape (Newmann \& Bailey 1987, Singh \& Tripathi 1994, Zhou 1994, Jiang et al. 1995). Husbandry measures, such as rotation, removal of stubble from the previous crop, stimulation of soil microorganisms and prevention of plant injury, may be helpful to reduce the disease (Kharbanda \& Tewari 1996, Twengstrom et al. 1998, Wahmhoff et al. 1998), but are laborious. Genotypes with apetalous flowers may be an alternative to be applied in areas where the natural infestation is heavy. 


\section{Summary - Previous study on apetalous rapeseed}

Previous reports concerning apetalous character in rapeseed can be summarized as follows:

- Apetalous flowers were found in most of the important species of Brassic oilseeds. Apetalous variants were either discovered spoutaneously in nature or produced artificially by remote crossing or chemical treatment.

- Dominant genes control petal development in oilseed Brassicas. The number of genes controlling apetalous trait is different for different species or genotypes.

- Changes of apetalous degree during flowering were observed. Experiments investigating the relationship between apetalous degree and internal or external factors were not found in literature.

- Apetalous genotypes have better distribution of PAR within canopy, and consequently, better vegetative growth. Apetalous trait was introgressed into commercial varieties. Up to $20 \%$ increase of harvest index and $40 \%$ increase in yield was reported.

- Petals were found important for infection and distribution of Sclerotinia disease. Field experiments comparing degree of infection between apetalous and normal petalled genotypes were not reported. 


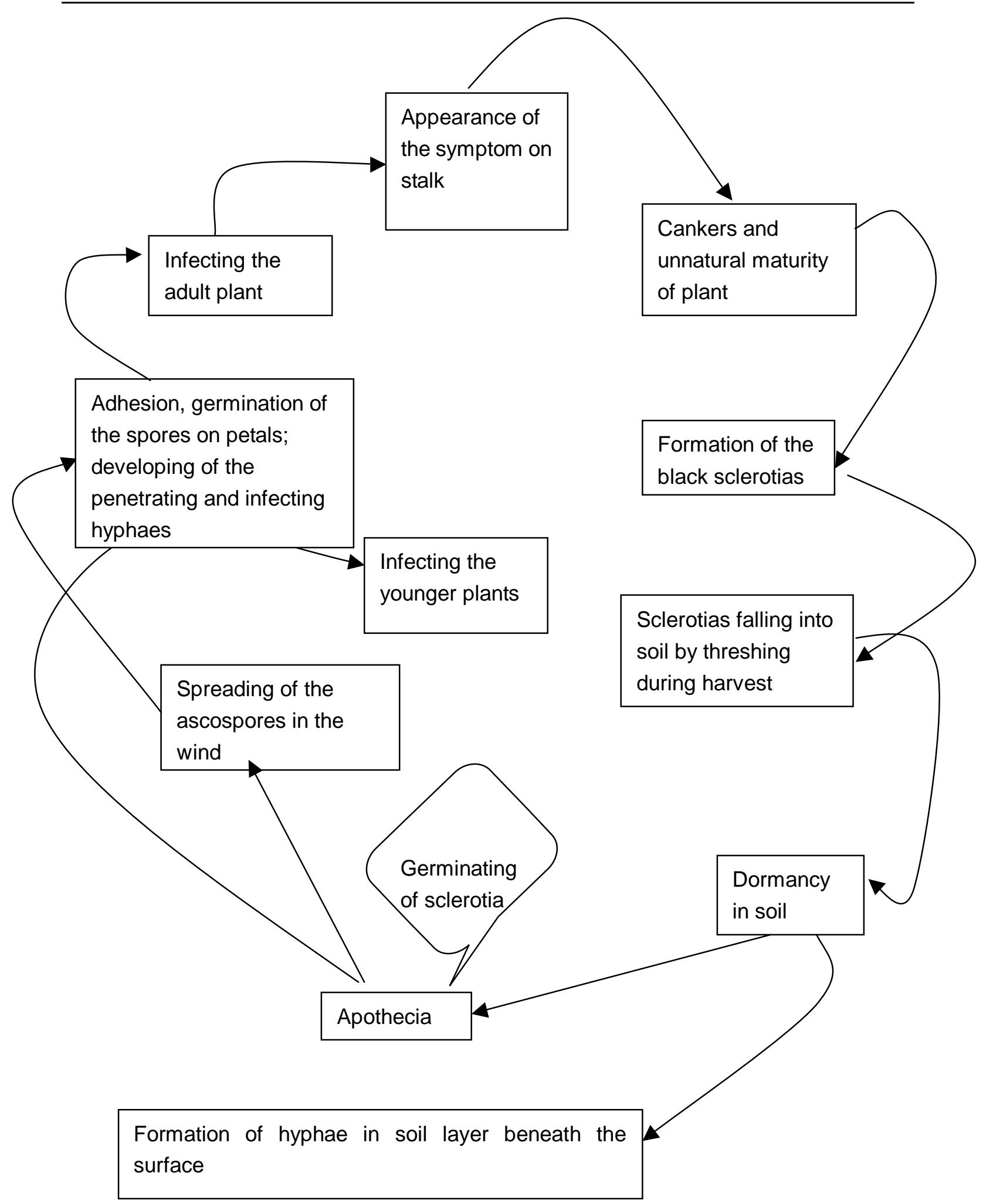

Figure 2-1 The life cycle of Sclerotinia sclerotiorum 


\section{MATERIALS AND METHODS}

\section{Plant materials}

The apetalous source is a mutant from a mutagenesis program (Tengbe 1990). The mutant had been selfed and selected for 6 generations before it became a homogenous line - 'ap-Tengbe' - with stable expression of complete aptalous flowers.

'Ap-Tengbe' was crossed with 'Falcon' and other cultivars. Different materials were developed and used in the experiments as shown in Figure 3-1. For some experiments two other sources of apetalous flowers ('ap-Renard' and 'ap-Camp.' were used.

(1) Inheritance of the mutant 'ap-Tengbe' with apetalous flowers (see 7.1)

Observed were the plants of 'ap-Tengbe', 'Faclon' and F1 ('Falcon' $x$ 'ap-Tengbe'), RF1 ('ap-Tengbe' x 'Falcon'), BC1-1(F1 x 'ap-Tengbe'), BC1-2 (F1 $x$ 'Falcon'), RBC1-1 ('ap-Tengbe' x F1), RBC1-2 ('Falcon' x F1), F2 (F1 x F1) and RF2 (RF1 x RF1).

(2) Influence of environmental effects on expression of apetalous flowers (see 7.2)

The plant materials described above were used also in the field experiment investigating PDgr changes during flowering in different natural environments.

For the investigation of hormones' effect on the expression of PDgr were the following DH lines: $\mathrm{DH} 1-1, \mathrm{DH} 1-2$ and $\mathrm{DH} 2-2$, which have normal flowers; $\mathrm{DH}$ 2-3 with partial apetalous flowers; and $\mathrm{DH}$ 3-3 and $\mathrm{DH}$ 3-7 with absolutely apetalous flowers. The $\mathrm{DH}$ lines were developed from F1 ('ap-Renard' $x$ 'ap-Tengbe)' by microspore culture according to protocol in Figure 3-2.

(3) Influence of apetalous flowers on crop physiology (see 7.3)

AP1: F6 ('ap-Tengbe' x 'Falcon') with apetalous flowers

HAP: F6 ('ap-Tengbe' $x$ 'Falcon') with partial apetalous flowers

NP1: F4 (F3 ('ap-Tengbe' x 'Falcon') x 'Falcon') with normal flowers 
'Falcon': German cv. as control

(4) Influence of apetalous flowers on infection from sclerotinia disease (see 7.4)

For the field experiment at Hangzhou 1998/1999

Except for AP1, HAP and NP1, which were described above, the following materials were applied:

AP2: F6 ('ap-Renard' $x$ ap-Tengbe') with apetalous flowers

AP3: F6 (('ap-camp' x 'Libraska') x 'Lirajet') with apetalous flowers

AP4: F4 ((F2 ('ap-Renard' x 'ap-Tengbe') x Bristol) with apetalous flowers, and 'ZY-758': Chinese cultivar used as control.

For the field experiments at Futterkamp and Birkenmoor 1999/2000

AP5: F2('ap-Tengbe' × 'DH-Samourai') with apetalous flowers

NP2: F2('ap-Tengbe' × 'DH-Samourai') with normal flowers

AP6: F2(((F7'ap-camp.'x'Libraska') x'Lirajet') $)$ 'Capitol') with apetalous flowers

NP3: F2(((F7'ap-camp.' $x$ 'Libraska') $\times$ 'Lirajet') $\times$ 'Capitol') with normal flowers

AP7: F2(((F7'ap-camp.''x'Libraska') $\times$ 'Lirajet') $\times$ 'Express') with apetalous flowers

NP4: F2(((F7'ap-camp.'x'Libraska')x'Lirajet') x'Express') with normal flowers

'Lirajet' and 'Express' as control 
Inheritance of 'ap-Tengbe' mutant with apetalous flowers (see 7.1)

Göttingen1998 and Hangzhou 1999
F1 ('Falcon' x 'ap-Tengbe'), RF1 ('ap-Tengbe' x 'Falcon'),
BC1-1( $F 1$ x 'ap-Tengbe'), BC1-2 (F1 x 'Falcon'),
RBC1-1 ('ap-Tengbe' x F1), RBC1-2 ('Falcon' x F1),
F2 (F1 x F1) and RF2 (RF1 x RF1)

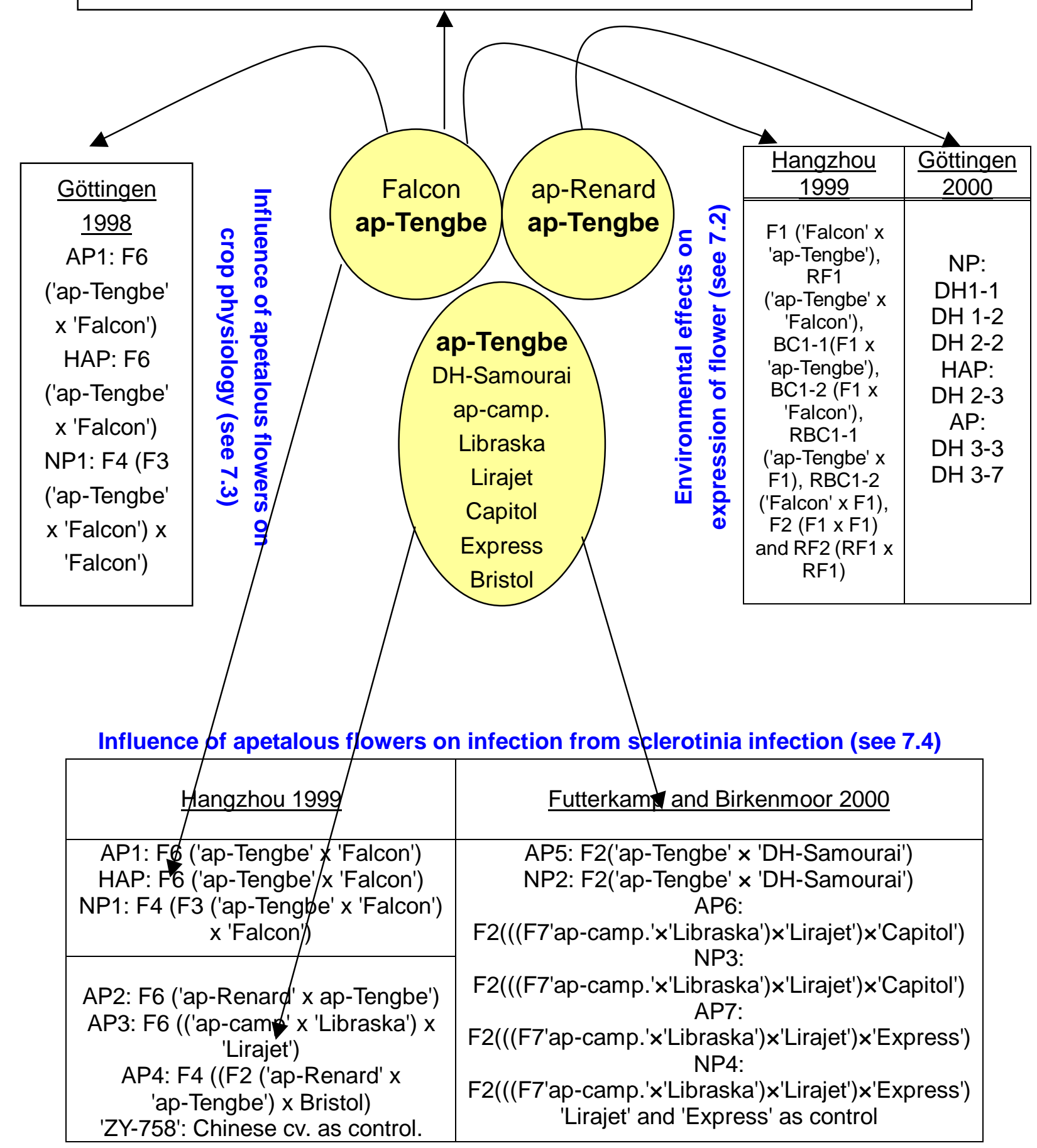

Figure 3-1 Plant materials used in the experiments 


\section{Methods}

(1) Inheritance of the mutant 'ap-Tengbe' with apetalous flowers (see 7.1)

The plant materials were field grown at Göttingen of northern Germany in $1997 / 98$ and at Hangzhou of southeast China in 1998/99. They were observed during flowering for segregation of PDgr (defined as in page 49). Genetic regulation of the apetalous character was hypothesized. The theoretic segregations were compared with the actual observations and examined by Chi-square test for the significance of difference.

\section{(2) Environmental effects on the expression of apetalous flowers (see 7.2)}

The materials were scored for PDgr at initial anthesis and at later flowering in the field at two locations (Göttingen and Hangzhou). Paired PDgr values, which were scored for a same plant at different flowering stages, were compared and tested for the significance of difference.

The $\mathrm{DH}$ lines were developed following the protocol sketched in Figure 3-2. The following hormone solutions were used: indoleacetic acid (IAA) (100 ppm), kinetin (20 ppm), 2.4-D (100 ppm), mixed Naphthaleneacetic acid (NAA) and Benzylaminopurine (BA) (NAA:BA=4:1) (100 ppm), Benzylaminopurine (BA) (20 ppm) and water as control. They were sprayed evenly on the $\mathrm{DH}$ plants about 8-14 days before anthesis. PDgr changes after the applications were carefully investigated.

PLABSTAT (Utz 1994) ANOVA for the reduction of PDgr on affected racemes, the reduction of PDgr of a whole plant and the numbers of affected racemes was performed to estimate least significant difference (LSD).

(3) Influence of apetalous flowers on crop physiology (see 7.3)

AP1, HAP, NP1 and 'Falcon' were tested in a field experiment of a split-split-plot design with three replications. Nitrogen was the main plot, plant density was the subplot and genotype was the sub-subplot. The nitrogen levels were without fertilization and with application of 100 or $200 \mathrm{~kg} \mathrm{~N} / \mathrm{ha}$; the plant densities at sowing were 30,80 and 120 plants $/ \mathrm{m}^{2}$. The experiment was carried out at the two locations Reinshof (near Göttingen) and Teendorf (near Uelzen, 
Lüneburger Heide) 1997/98.

At both locations, grain yield, oil and protein content were determined. At Reinshof, additional parameters, such as the weight of floral organs, photosynthetic active radiation at initial and at peak flowering stages, the leaf area index before anthesis, at peak flowering and after flowering, weight of total biomass, were measured during the vegetation period.

ANOVA was performed using the software PLABSTAT (UTZ 1994). Statistical significance was tested by appropriate F-Test.

(4) Influence of apetalous flowers on infection of Sclerotinia disease (see 7.4) Randomized complete blocks design with 3 repetitions was applied for the field experiments at Hangzhou 1998/1999, and at Futterkamp and Birkenmoor 1999/2000.

Infected rate (IR) and severity index of the infected plants (SI) under the natural condition were scored in the field at Hangzhou 1999.

Some enzyme tests were compared for their efficiency in quantitatively identifying the infection degree (ID). Protease and xylanase tests were chosen to determine the differences of ID among apetalous lines and their normal petalled sister lines of the field experiment at Futterkamp and Birkenmoor in northern Germany 2000. 


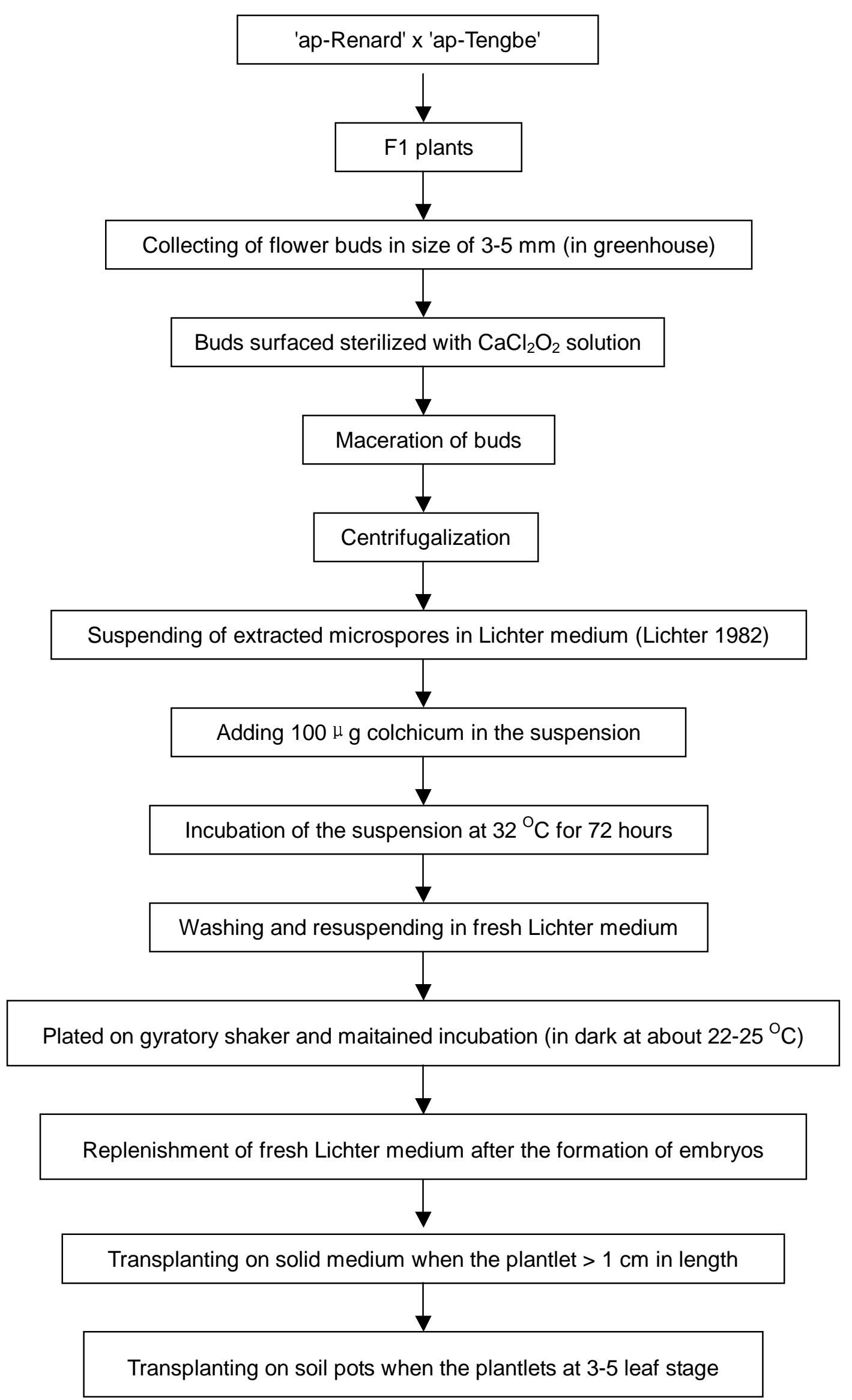

Figure 3-2 The process of microspore culture and development of $\mathrm{DH}$ lines 


\section{RESULTS AND DISCUSSION}

\subsection{Inheritance of the mutant 'ap-Tengbe' with apetalous flowers and environmental effects on expression of apetalous flowers}

How does the mutant 'ap-Tengbe' look like?

The mutant 'ap-Tengbe' is winter type of Brassica napus. Some of its leaves show lack of chlorophyll and become white after vernalization but recover green in 5-7 days. It grows relative slowly at vegetative stage and hence gets mature 7-10 days later compared with the commercial German cultivar 'Falcon'. In comparison with other apetalous sources, i.e. the French apetalous line 'ap-Renard' and the Canadian spring type 'ap-AAFC', and German spring type 'ap-NPZ'. The 'ap-Tengbe' has the most stable and complete apetalous flowers.

How are the apetalous flowers in the mutant 'ap-Tengbe' genetically regulated? (see 7.1)

The apetalous character in 'ap-Tengbe' is controlled by the interaction of cytoplasmic substance and two nuclear genes. Normal petalled plants have normal cytoplasm $\left(C_{N}\right)$ and four nuclear alleles coding normal petals $\left(P_{1} P_{1} P_{2} P_{2}\right)$, whereas the apetalous 'ap-Tangbe' mutant has apetalous cytoplasm $\left(C_{a p}\right)$ and four alleles coding the absence of petals $\left(p_{1} p_{1} p_{2} p_{2}\right)$. Alleles for petals are dominant to those for apetalous flowers. The Genetic interpretations for apetalous, partial apetalous and normal petalled phenotypes are summarized in Table 7.1-3.

The F1 plants ('Falcon' $\mathrm{x}$ 'ap-Tengbe'), which have $C_{N}$ and the nuclear genes $P_{1} p_{1} P_{2} p_{2}$, showed normal petals. The RF1 plants ('ap-Tengbe' x 'Falcon'), which have $C_{a p}$, still showed normal petals due to dominant effect of both $P 1$ and $P 2$ alleles. In $\mathrm{BC} 1-1$ or $\mathrm{F} 2$ plants with $C_{N}$, which influences the expression of apetalous character from $p_{1}$ or $p_{2}$, only the genotypes with $p_{1} p_{1} p_{2} p_{2}$ were able to express a certain degree of apetalous character and the genotypes with three or less recessive alleles of $p_{1}$ and $p_{2}$ had normal petals. Segregations in $\mathrm{BC} 1-1$ and F2 populations were 0:1:3 and 0:1:15 respectively for apetalous, intermediate and normal petalled types. However, the RBC1-1 or RF2 plants 
with $C_{a p}$ cytoplasm showed a segregation of $1: 2: 1$ or $1: 6: 9$ for apetalous, intermediate and normal petalled types, respectively. Because the BC1-2 and the RBC1-2 plants have either $C_{N}\left(P_{1}{ }_{-}{ }_{-}\right)$or $C_{N}\left({ }_{-} P_{2}\right)$, they performed normal petalled phenotype. No true apetalous type was found in these two populations.

The actual observed segregation in RF2 ('ap-Tengbe' x 'Falcon') population was 10:64:128 for apetalous, intermediate and normal petalled types. Two alternative genetic interpretations are possible. If we assume that genes would act independently and additively, it agreed to the theoretical segregation of 1:6:9. However, if the gene for normal petals would be epistatically over the apetalous gene in the genotypes $C_{a p}\left(P_{1} P_{1} p_{2} p_{2}\right)$ or $C_{a p}\left(p_{1} p_{1} P_{2} P_{2}\right)$, then the expected segregation is 1:5:10. According to Chi-square test both situations were possible.

The inheritance of apetalous flowers in 'ap-Tengbe' mutant resembles that of cytoplasmic male sterility (CMS) in the way that the cytoplasm interacts with nuclear genes in determining phenotypes (Yang \& Fu 1990, Stiewe \& Röbbelen 1994, Delourme \& Budar 1999). It was recognized that CMS was often linked with small petals or a reduced petal number (McVettv et al. 1989, Malik et al. 1999). We also observed in 'ap-Tengbe' mutant a reduced pollen production (data not shown).

Cytoplasmic effects on the inheritance of apetalous character have not been previously shown, although in Buzza's (1983), and Lü \& Fu's (1990) studies cytoplasmic effects were investigated. They made crosses between their apetalous materials and normal petalled parents and compared the reciprocal F1 and F2 populations without observing significant cytoplasmic effects.

Are there external or internal environmental effects on the expression of PDgr? (see 7.2)

Environmental affects, in particular some phytohormones, have clear effect on the expression of apetalous flowers during flowering.

It was found that PDgr was reduced at later flowering stage both at Göttingen, Germany, and Hangzhou, China. Moreover, the degree of the 
reduction was different in the two environments indicating an external effect on the expression of PDgr. Internal hormones' adjustment was further proved by our field experiment at Göttingen 2000. We observed that the supply of auxins or cytokinins resulted in reduction of PDgr in the partial or the normal petalled DH plants. The expression of PDgr in plants with apetalous gene(s) was very probably dynamically determined by external conditions as well as the balance of endogenous hormones subjecting to change at different growth phases.

Our investigation showed that a higher reduction of PDgr took place during flowering in genetic populations with abnormal cytoplasm $\left(C_{a p}\right)$. It would be possible that the apetalous $(\mathrm{PDgr}=0)$ or less petalous character $(\mathrm{PDgr}<90)$ was caused by excessive synthesis of endogenous cytokinin or/and auxin or perhaps other kinds of hormones in plant cells at flowering phase, catalyzed by the two recessive and cytoplasmic genes that acted additively. The malfunction of the genes would be probably caused by point mutation induced by chemical treatment.

There is not much information available about the role of hormone in formation and differentiation of floral organs in Brassica napus. However, as Brassica napus and Arabidopsis thaliana are both members in the family Brassicaceae and the genomes of Brassica and Arabidopsis are collinear, information on the regulatory genes that control and coordinate the determination, differentiation and morphophogenesis of the floral meristem and floral organs in Arabidopsis thaliana (Oka et al. 1999) may be used as reference to Brassica napus. It was found that application of BA to inflorescences at certain developmental stages resulted in increase in floral organ number, formation of abnormal floral organs as well as induction of secondary floral buds in the axils of sepals. Venglat et al. (1996) explained that exogenous BA suppresses the normal functioning of the genes for floral meristem identity and thereby affects flower development and the later stages of floral organ differentiation. In our experiment, increases in floral organ number and induction of secondary floral buds in the axils of sepals were not observed. 


\subsection{Effect of petals on yield physiology and the relationship between petals and Sclerotinia infection}

Do other floral organs benefit from reduction of petals? (see 7.3)

Our result shows that the weight of petals is significantly and negatively correlated with the weight of pistil, pedicel and calyx. This indicates, that the elimination of petals benefits the development of the other floral organs.

It was found that the tested line with normal flowers (NP1) had the largest weight of whole flower, which was $6.8 \%$ and $20.18 \%$ heavier than that of the apetalous line (AP1) and the partial apetalous line (HAP), respectively. The three genotypes differed significantly for all other parts of the flower, too. For all floral organs except petals, the AP1 genotype had the heaviest floral organs.

Without or with fewer petals, the plants maintain more photosynthesized assimilates in leaves or other floral organs, as the petal is no photosynthesizing organ but only consuming photosynthesized assimilates. According to Mendham et al. (1981), around 25000 flowers per m2 were produced by typical European cultivars of winter oilseed rape, that equivalents approximately 125-200 $\mathrm{g}$ dry matter per $\mathrm{m}^{2}$, if we assume that petals of a normal flower weigh $6-8 \mathrm{mg}$.

Do petals influence PAR transmission? (see 7.3)

Measuring PAR absorption at the base of flower layer at peak flowering revealed an obvious effect of the petals, depending in magnitude on the agronomic treatment. Without nitrogen and at low plant density of about 30 plants $/ \mathrm{m}^{2}$, the effect of genotype on PAR absorption was not significant, whereas with high nitrogen fertilization $(200 \mathrm{kgN} / \mathrm{ha})$ and high plant density (120 plants $/ \mathrm{m}^{2}$ ), the PAR absorption of AP1 was significantly smaller than that of HAP and NP1, yet there was no significant difference between HAP and NP1. Thus, the petals are limiting light transmission to the leaves directly below the flower layer, especially with higher $\mathrm{N}$ application and at high plant density.

In our investigations, by measurement on the soil surface, there was little difference between AP1 and NP1, indicating petals may have little effect 
influencing the PAR transmission on the basal leaves of the plant.

Do petals have negative effect on leaf area index (LAI)? (see 7.3)

Our investigation shows that petals have no negative effect until peak flowering stage, when, in general, the LAl of AP1 was about $28 \%$ higher than that of HAP, and the difference between HAP and NP1 was enlarged also. The German cultivar 'Falcon' had the highest LAl before anthesis, but AP1 surpassed 'Falcon' significantly at peak flowering by about $11.6 \%$. Three weeks after end of flowering, HAP surpassed Falcon for LAI too. AP1 and HAP had about $37.9 \%$ and $27.6 \%$ more remaining active green leaves than NP1 in average.

However, petal's effect on LAI depends on nitrogen application and plant density. We found that at peak flowering, the petals had no clear effect at low nitrogen level. However, with $200 \mathrm{~kg} \mathrm{~N} / \mathrm{ha}$, and in particular low density (30 plants $\left./ \mathrm{m}^{2}\right)$, AP1 had clearly a greater LAl than HAP and NP1, and even higher than 'Falcon', while HAP had greater LAI than NP1. Increasing the amount of nitrogen results in an increase in LAI regardless of the shading effect. Two weeks after flowering, the LAls were very small without or with application of only $100 \mathrm{~kg} \mathrm{~N} / \mathrm{ha}$. However, under high nitrogen application (200 kg N/ha), LAI of AP1 responded positively to increasing population density and reached the maximum with 120 plants $/ \mathrm{m}^{2}$. LAl of NP1 reached almost the maximum with 80 plants $/ \mathrm{m}^{2}$, and increased not significantly when population density was raised to 120 plants $/ \mathrm{m}^{2}$.

Do petals have negative effect on total biomass? (see 7.3)

Petal's negative effect on total biomass is clearly demonstrated by our investigation. AP1 had a higher biomass than HAP, while HAP had a higher biomass than NP1 in most circumstances, in particular with very high nitrogen application plus very high population density, where AP1 had approximately 35 $\%$ more total biomass than HAP, and HAP had $26 \%$ more total biomass than NP1. Generally, total biomass responded slightly positive to increasing nitrogen application. The response of total biomass to increasing population density was not clear; it largely depended on nitrogen level and flower type. 
Is there any advantage for grain yield of apetalous genotypes? (see $7.3 \& 7.4$ )

The effect of apetalou flowers on grain yield differed for different genetic sources of apetalous flowers. No yield advantage was found in the apetalous line (AP1) with 'ap-Tengbe' background. In our experiments at Reinshof and Teendorf in 1998, mean yield of AP1 was lower than that of HAP. Mean yield of AP1 and HAP was significantly lower than that of the NP1 and Falcon, and there was no significant difference between AP1 and HAP, or between NP1 and Falcon for grain yield at the both location. The lower yield performance of AP1 might be due mainly to the lower pollen production. Moreover, AP1 had a shorter duration of flowering, which was 2-3 days shorter than that of NP1 and 3-5 days shorter than that of Falcon. The positive effect of longer flowering duration on yield was suggested by Asthan \& Pandey (1977) and Olivieri \& Parrini (1979).

However, in the other experiments at Futterkamp and Birkenmoor in 2000, the apetalous line (AP6) with 'ap-camp.' background showed significantly higher yield than its sister line (NP3) with around 15\% more yield at both locations.

Besides the reduced shading effect, which is generally regarded as an advantage, the apetalous genotypes may have other advantages benefiting yield. One might be the effect of reduced evaporation, which permits greater drought tolerance. In an experiment in Australia, up to $48 \%$ higher yield for the breeding line without petals was attained in comparison to the Australian commercial variety 'Marnoo' in a drought environment. The apetalous line benefited not only from less evaporation, but also from higher root activity, which was promoted by longer active leaf life, while normal petalled crops generally show little increase in root weight after flowering started. Apetalous types maintained a consistently higher stomatal conductance than 'Marnoo', but also a higher leaf turgor at lower osmotic potentials. All these led to better yield performance in a drought environment (Mendham et al. 1991).

Are the apetalous genotypes less infected from Sclerotinia disease? (see 7.4) In general, apetalous genotypes are less infected from Sclerotinia disease. It was found by field scoring in Hangzhou, China that all the apetalous lines were 
lower in infected rate $(\mathrm{IR})^{1}$ than the partial apetalous and normal petalled genotypes. However, there was no significant difference among the genotypes for severity index $(\mathrm{SI})^{2}$ of the infected plants. In the experiments at Futterkamp and Birkenmoor in northern Germany, it was demonstrated by protease and xylanase tests that the line with least infection degree (ID) ${ }^{3}$ was the apetalous type (among 8 tested lines including 2 German commercial varieties) and the three apetalous lines were all less infected than their normal petalled sister lines under both treatments with or without fungicide application during flowering. The advantage was clear when the apetalous lines were compared to their respective normal sister lines. However, when comparing the apetalous lines with two German cultivars, there was no clear advantage of apetalous lines.

Our explanation would be that the infection of disease could be determined by many factors, including the maturity of the genotypes. In this experiment, 'Express' and 'Lirajet' were earlier in flowering than all tested apetalous lines. Perhaps the disease pressure might be lower at earlier stages and the apetalous lines might suffer from heavier disease press when they were starting flowering.

Petal's role in distributing disease may be not only limited to Sclerotinia sclerotiorum. The spores of some pathogens, e.g. Botrytis cinierea (Jamaux 1994) and Peronospora parasitica (Lü \& Fu 1990), which causes symptoms during or shortly after flowering, were also found on petals. Lefol \& Morrall (1999) even discovered more than 50 groups of ascospores existing on rape petals, among which some are aggressive. Genotypes with apetalous flowers might have the advantage to avoid these diseases too.

\footnotetext{
${ }^{1}$ The definition of infected rate (IR) see page 93.

${ }^{2}$ The definition of severity index (SI) see page 94 .

${ }^{3}$ The definition of infection degree (ID) see page 95
} 


\subsection{Conclusions}

1.

The genetic analysis of apetalous character in 'ap-Tengbe' was based on segregation of petalous degree (PDgr). The inheritance of apetalous flowers in 'ap-Tengbe' mutant resembles that of cytoplasmic male sterility (CMS) in the way that the cytoplasm interacts with nuclear genes in determining phenotypes. It is regulated by an interaction of cytoplasmic genes and two pairs of nuclear genes. Completely apetalous flowers are only expressed in genotype with the 'ap' cytoplasm and two homozygous recessive genes $\left(p_{1} p_{1} p_{2} p_{2}\right)$. The 'ap-Tengbe' mutant can be successfully used to develop completely apetalous breeding lines, but cytoplasmic effects have to be considered.

2.

The expression of apetalous flowers was, however, found unstable during flowering. It was observed that petalous degree (PDgr) decreased from initial anthesis to end of flowering both in the partial apetalous and the normal petalled plants with apetalous gene(s) and that the supply of auxins or cytokinins resulted in reduction of petalous degree.

It is very likely that the apetalous $(\mathrm{PDgr}=0)$ or less petalous character $(P D g r<90)$ is caused by excessive synthesis of endogenous cytokinin or/and auxin and perhaps other kinds of hormones in plant cells at flowering phase catalyzed by the two recessive and cytoplasmic genes that acted additively. The malfunction of the genes would be probably caused by point mutation induced by chemical treatment.

3.

Petals largely reduce the transmission of photosynthetic active radiation (PAR) to the upper leaves of rape plants, but they have rather limited influence on PAR transmission on basal leaves. Petals have negative effects on leaf area index (LAI) and duration of active green leaves as well as on total biomass. They have, however, no negative effects on oil and protein content of seed.

Yield advantage of apetalous genotypes differs for various genetic sources for this trait. Apetalous lines with 'ap-Tengbe' background had a disadvantage in grain yield probably due to less pollen production. Another apetalous line, 
which was developed from the apetalous source 'ap-camp.', showed higher yield in comparison to its sister line with normal flowers..

4.

Analyses of protease and xylanase with appropriate concentrations of the exaction of infected plant tissues are efficient in quantitatively determining infection degree (ID) from Sclerotinia disease.

Apetalous lines are less infected from Sclerotinia disease in comparison to their normal petalled sister lines. They did not show significant lower ID in comparison to the two German varieties as control. It could be that they suffered from heavier press from the disease when they were starting flowering.

Petal's role in distributing disease may be not only limited for Sclerotinia sclerotiorum. The spores of some pathogens, e.g. Botrytis cinierea and Peronospora parasitica, which causes symptoms during or shortly after flowering, were also found on petals 


\section{SUMMARY}

Apetalous genotypes might be of interest in oilseed rape breeding because of their more efficient photosynthesis and reallocation of the photosynthesized assimilates and a lower probability of infection from pathogens distributed by petals. The mutant 'ap-Tengbe' with apetalous flowers and some breeding lines with complete or partial apetalous flowers were investigated for (1) the genetic regulation of apetalous flowers, (2) environmental effects, in particular the effect of some phytohormones, on expression of the petalous degree (PDgr), (3) the crop physiology, and (4) the infection from Sclerotinia disease.

The German cultivar 'Falcon' was crossed with 'ap-Tengbe'. The F1, the two $\mathrm{BC} 1$ generations and their reciprocal forms, as well as the $\mathrm{F} 2$ were grown for observation of petalous degree (PDgr) in field experiments at Göttingen, Germany, 1998 and Hangzhou, China, 1999. The reciprocal F2 population was grown only at Hangzhou in 1999. The segregation of PDgr in various generations was recorded.

The above materials were also observed for the changes of PDgr during flowering in the two environments. Moreover, in a field experiment at Göttingen 2000, double haploid (DH) lines with apetalous, partial apetalous and normal petalled flowers were treated with auxins and cytokinins and the effect of the hormones on the expression of PDgr was investigated.

Crop physiology of an apetalous line with improved agronomic traits was compared with that of a partial apetalous and a normal petalled sister lines. Field experiments were grown at three plant densities and three nitrogen levels at two locations in northern Germany.

Four apetalous lines, one partial apetalous and two normal petalled lines were field grown for the investigation of infected rate (IR) and severity index (SI) from Sclerotinia sclerotiorum disease by field scoring in Hangzhou China 1999. In addition, three other apetalous lines, their normal petalled sister lines and two German varieties were grown at two locations in northern Germany 2000. Some enzyme tests were compared for their efficiency in identifying the infection degree (ID) quantitatively. Stem samples were analyzed for infection degree (ID) from Sclerotinia disease by protease and xylanase tests. 
The results reveal that

- the apetalous character in 'ap-Tengbe' is regulated by an interaction of cytoplasmic genes and two pairs of nuclear genes. Completely apetalous flowers are only expressed in genotypes with the 'ap' cytoplasm and two homozygous recessive genes $\left(p_{1} p_{1} p_{2} p_{2}\right)$.

- PDgr decreases from initial anthesis to end of flowering in materials with apetalous parent involved. The reduction of PDgr in these plants is caused by endogenic accumulation of auxins or/and cytokinins during flowering.

- petals largely reduce the transmission of photosynthetic active radiation to the upper leaves. They have negative effects on leaf area index (LAI) and duration of active green leaves as well as on total biomass dry matter weight. They have, however, no negative effects on oil and protein content of seed. Yield advantage of apetalous genotypes differs for various genetic sources for this trait. Apetalous lines with 'ap-Tengbe' background had a disadvantage in grain yield probably due to less pollen production.

- $\quad$ apetalous lines are less infected from Sclerotinia disease in comparison to their normal petalled sister lines. Analyses of protease and xylanase with appropriate concentrations of the exaction of infected plant tissues are efficient in determining infection degree from Sclerotinia disease quantitatively.

In conclusion, the mutant 'ap-Tengbe' can be successfully used to develop completely apetalous breeding lines, but cytoplasmic effects have to be considered. Apetalous lines have a potential to increase grain yield and Sclerotinia resistance. For future breeding, 'ap-Tengbe' would be more valuable if the genetic linkage between apetalous flowers and low pollen production could be broken. 


\section{REFERENCES}

Afshari-Azad H, 1992. Produktion extracellulärer, hydrolytischer Enzyme von Pseudocercosporella herporella herpotrichoides (Fron) Deighton, Fusarium culmorum (W.G.SM) SACC sowie Rhizoctonia cerealis in vitro bzw. in planta und ihre Beziehung zur Pathogenese. Diss., Universität Göttingen

Alam Z and Muhammad A A, 1953. Inheritance of some pod-characters in some oleiferous Brassica of the Punjab. Proceedings of the Fifth Pakistan Science Conference, Lahore. Part II: pp. 13-14

Ali Mohammed and Sikka S M, 1937. Breeding investigations in some of the oleiferous Brassicae of Punjab. Indian J. Agricult. Sci. 7: 849-862

Asthana A N \& Pandey U K, 1977. Combining ability and rank correlation in diallel cross of Indian Mustard B. juncea. Exp. Agric. 13: 71-79

Austin R B, Ford M A, Edrich J A and Hooper B E, 1976. Some effects of leaf posture on photosynthesis and yield in wheat. Ann. Appl. Bio. 83: 425-446

Awad A, Dawh AK and Attya M, 1987. Cutting thickness and auxin affecting the rooting and consequently the growth and flowering of Bougainvillea glabra $L$. Acta Horticulturae. 2: 445-454

Bateman D F and Basham H G, 1976. Degradation of plant cells and membranes by microbial enzymes. In: R. Heitefuss and Williams (Eds.): Physiological Plant Pathology. Springer Verlag, Berlin-Heidelberg-New York: 316-345

Becker H C, 1993. Quantitative Genetik. Pflanzenzüchtung. Ulmer Stuttgart. pp: 108-126

Becker H C, Löptien H and Röbbelen G, 1999: Breeding: an overview. In: C. Gómez-Campo C (ed). Biology of Brassica Coenospecies. Elsevier, Amsterdam. pp: 413-447

Bentota A P, Senadhira D and Lawrence M J, 1998. Quantitative genetics of rice. III. The potential of a pair of new plant type crosses. Field Crops Res. 55: 


\section{$267-273$}

Brar B K, Dhillion S S, Singh K and Labana K S, 1991. Genetics of qualitative traits in Indian mustard. Cruciferae Newsletter. 14/15: 34-35

Brown P H and Menary R C, 1994. Flowering in pyrethrum (Tanacetum cinerariaefolium L.). II. Changes in plant growth regulator concentrations. Journal of Horticultural Science 69: 985-992

Buzza G C, 1983. The inheritance of an apetalous character in Canola ( $B$. napus L.). Cruciferae Newsl. 8: 11-12

Chang S T, Chen W S, Hsu C Y, Yu H C, Du B S, Huang K L, 1999. Changes in cytokinin activities before, during and after floral initiation in Polianthes tuberosa. Plant Physiology and Biochemistry. 37: 679-684

Chapman J F, Daniels R W and Scarisbrick D H, 1984. Field studies on ${ }^{14} \mathrm{C}$ assimilate fixation and movement in oilseed rape (B. napus). J. Agricult. Sci., Cambridge. 102: 23-31

Chay $P$ and Thurling $N, 1989$. Variation in pod length in spring rape (B. napus) and its effect on seed yield and yield components. J. Agricult. Sci., Cambridge: 113: $139-147$

Chen B Y and Heneen W K, 1990. Independent inheritance of flower color and male-fertility characters in Brassica napus L. Plant Breed. 104 (1): 81-84

Chen B Y, 1989. Apetalous flower. Resynthesized Brassica napus L.: A potential in breeding and research. Dissertation, The Swedish University of Agricultural Sciences, Svalöv. pp: 3-29

Chen B Y, Heneen W K, Jönsson R, 1988. Resnythesis of Braasica napus L. through interspecific hybridization between $B$. alboglabra Bailey and $B$. campestris L. with special emphasis on seed color. Plant Breed. 101: 52-59

Cooper R M and Wood R K S, 1975. Regulation of synthesis of cell wall degrading enzymes by Verticillium albo-atrum and Fusarium oxysporum f. sp. Lycopersici. Physiol. Plant Pathol. 5: 135-156 
Cours B J and Williams P H, 1977. Genetic studies in Brassica campestris L.. Plant Breed. Abstr. 51: 1533

Davies P J, 1987. The phytohormones: Their nature, occurrence, and functions. In: Davies P J (eds.), Phytohormones and their role in plant growth and development. Martinus Nijhoff Publishers. pp: 5

Delourme R and Budar F, 1999. Male sterility. In: Gómez-Campo C. (eds), Biology of Brassica Coenospecies. Elsevier, Amsterdam. pp: 185-216

Delwiche P A and Williams P H, 1977. Genetic studies on Brassic nigra (L.) Koch. Cruciferae Newsletter. No 2: 39

Dohhon S S, Chandra S, Basu A K and Makhija O P, 1982. Component of genetic variation for yield and its attributes in a diallel cross of yellow seeded sarson (Indian Colza) . Indian J. Agricult. Sci. 52: 154-158

Downey R K and Rakow G 1987. Principles of cultivar development - Crop Species. Fehr W R (eds). Macmillan Publications. Comp. New York. Vol 2. pp: 437-486

Eliseev I P, 1979. The origin, polymorphism and evolutionary importance of apetalous apple forms. Plant Breed. Abstr. 52: 2338

Fang J and Platford R G, 1994 Distribution, prevalence and incidence of canola diseases in Manitoba. Canadian Plant Disease Survey 75: 145-147

FAO production yearbook 1996-1999. FAO on line statistics, http://www.fao.org/

Fray M J, Evan E J, Lydiate D J and Arthur A, 1996. Physiological assessment of apetalous flowers and erectophile pods in oilseed rape (Brassica napus). J. Agric. Sci., Cambridge, 127: 193-200

Fray M J, Puangsomlee P, Goodrich J, Coupland G, Evans E J, Arthur A E and Lydiate D J, 1997. The genetics of stamenoid petal production in oilseed rape (Brassica napus) and equivalent variation in Arabidopsis thaliana. Theor. Appl. 
Genet. 94: 731-736

Getinet A, Rakow G and Downey R K, 1993. Inheritance of a cream petal mutant in Ethiopian mustard. Can. J. Plant Sci. 73: 1075-1076

Grimbly P E, 1980. An apetalous male sterile mutant in cucumber. Plant Breed. Abstr. 51: 11023

Habekotte B, 1997. Options for increasing seed yield of winter oilseed rape (Brassica napus L.): A simulation study. Field Crops Res. 54: 109-126

Hawk J A and Crowder L V, 1978. The inheritance of four mutants in early flowering. Brassic campestris L.. J. Heredity. 69: 125-127

Heitefuss R, König K, Obst A and Rescheke M, 1987. Weißstengeligkeit. Pflanzenkrankheiten und Schädlinge im Ackerbau. pp : 88-89

Heyn F W, 1973. Beiträge zum Auftreten unreduzierter Gameten und zur Genetik einiger Merkmale bei Brassiceae. Thesis. Georg-August-Universität Göttingen. pp: 102

Hoffmann G M and Schmutterer H, 1983. Rapskrebs. Parasitäre Krankheiten und Schädlinge an Landwirschaftlichen Kulturpflanzen. pp: 330-331

Jamaux D I, Gelie B, Lamarque C, 1994. Early stages of infection of rapeseed petals and leaves by Sclerotinia sclerotiorum revealed by scanning electron microscopy. Plant Pathology (Oxford) 44: 22-30

Jamaux D I, Spire D, 1999. Comparison of responses of ascospores and mycelium by ELISA with anti-mycelium and anti-ascospore antisera for the development of a method to detect Sclerotinia sclerotiorum on petals of oilseed rape. Annals of Applied Biology 134: 171-179

Jellis G J, Davis J M L and Scott E S, 1984. Sclerotinia on oilseed rape: Implications for crop rotation. Proceedings. British Crop Protection Conference-Pests and Diseases 2: 709-715

Jiang L X, Yu J B, Jin M S and Jiang W L, 1995. Evaluation of resistance to 
Sclerotinia sclerotiorum and TuMV virus for 140 land races (B. napus) in Zhejiang, Acta Agricult. Zhejiangensis 7: 202-205

Jönsson $R, 1975$. Yellow seeds in swede rape and turnip rape. II. Breeding for improved quality of oil and meal in yellow-seeded. Sveriges Utsädesförenings Tidskrift 85: 271-278

Kadkol G P, 1987. Genetic, anatomical and breeding studies of shattering-resistance in rapeseed (Brassica campestris L. and Brassica campestris L.). Diss. Abstr. International, B (Sciences and Engineering) 47 : 2681B

Kaur S R, Applewhite P B, Galston A W, 1996. Formation in vitro of ripe tomato fruits from thin layer explants of flower pedicels. Plant Growth Regulation 18: 191-199

Kelly A, Fray M, Arthur E A and Lydiate D J, 1995. The genetic control of petalless flowers and upright pods. Gnetics and Methods. Proc. $9^{\text {th }}$ International Rapeseed Congress, Cambridge UK 1995. pp: 732-733

Kharbanda P D and Tewari J P, 1996. Integrated management of canola diseases using cultural methods. Canadian Journal of Plant Pathology 18: 168-175

Krüger W, 1975. Die Beeinflussung der Apothezien- und AscosporenEntwicklung des Rapskrebserregers Sclerotinia sclerotiorum (Lib.) de Bary durch Umseltfaktoren. Pfl. Krankh. 2: 101-108.

Krüger W, 1975: Die Beeinflussung der Apothezien- und AscosporenEntwicklung des Rapskrebserregers Sclerotinia sclerotiorum (Lib.) de Bary durch Umseltfaktoren. Pfl. Krankh. 2, 101-108

Larmarque C, 1983. Conditions climatiques qui favorisent le processus naturel de la contamination du colza par le Sclerotinia sclerotiorum. Proc. $6^{\text {th }}$ International Congress Paris France. pp: 957-962

Lefol C, Morrall R A A, 1996. Immunofluorescent staining of sclerotinia ascospores on canola petals. Canadian Journal of Plant Path. 18: 237-241 
Liu H L, 1985. Remote crossing. In: Liu H L (ed.), Genetics and Breeding of Rapeseed, Shanghai Publishing House for Science and Technical Literatures, Shanghai. pp: 87-119

Lu W L, Liang B, Enomoto K, Fukunaga Y, 1994. Role of exogenous hormones in inducing cells in different positions of perianth explants to regenerate flower buds in Hyacinthus orientalis. Acta Botanica Sinica 36: 581-586

Lü Z J and Fu S Z , 1990. Inheritance of apetalous character in Rape (Brassica napus $\mathrm{L}$.) and its implication in breeding. Jiangsu J. Agricult. Sci. 6: 30-36

Malik M, Vyas P, Ranggaswamy N S, Shivanna K R, 1999. Development of two new cytoplasmic male-sterile lines in Brassica juncea through wide hybridisation. Plant Breed. 118: 75-78

Mc Lean D M, 1958. Role of dead flower parts in infection of certain crucifers by Sclerotinia sclerotiorum (Lib.) De. Bary. Plant Disease Rep. 42: 663-666

McVetty P B, Pinnisch R and Scarth R, 1989. The significance of floral characteristics in seed production of four rape cultivar A-lines with pol cytoplasm. Can. J. Plant Sci. 69: 915-918

Menary R C and Staden J V, 1976. Effect of phosphorus nutrition and cytokinins on flowering in the tomato, Lycopersicon esculentum Mill. Australian Journal of Plant Physiology 3: 201-205

Mendham N J, RAO M S S and Buzza G C, 1991. The apetaous flower character as component of a high yielding ideotype. Proc. GCIRC $8^{\text {th }}$ International Rapeseed Congress, Saskatoon, Canada. pp: 596-600

Mendham N J, Shipway P A and Scott R K, 1981. The convergent evolution of annual seed crops in agriculture. Adv. in Agron. 36: 97-143

Metzger D J, 1987. Hormones and reproductive development. In: Davies P J (eds.), Phytohormones and their role in plant growth and development. Martinus Nijhoff Publishers. pp: 443-450 
Mo J G, Li W Q and Wang J H, 1992. Inheritance and agronomic performance of the waxless character in Brassica napus L. Plant Breed. 108: 256-259

Mo J G, Li W Q, Yu Q and Bodnaryk R P, 1995. Inheritance of the waxless character of Braasica napus Nilla glossy. Can. J. Plant Sci. 75: 893-894

Morice J, 1960. Inheritance of flower color in rape, B. napus L. var. oleiferi Metzger. Ann. Inst. Nat. Rech. Agron, Paris Ser. B. 10: 155-168

Murphy D J, 1994. Brassica species. Designer Oil Crops Breeding, Processing and Biotechnology. $\mathrm{VCH}$ Verlagsgesellschaft mbH. pp: 27-36

Nayar G G and George K P, 1970. Inheritance of pod arrangement and seed color in B. juncea. Indian J. Genet. 30: 579-580

Newmann P L and Bailey D J, 1987. Screening for resistance to sclerotinia sclerotiorum in oilseed rape in the glasshouse. Ann. Appl. Biol. 110: 150-151

Oka M, Miyamoto K, Okada K and Ueda J, 1999. Auxin polar transport and flower formation in Arabidopsis thaliana transformed with indoleacetamide hydrolase (iaaH) gene. Plant and Cell Physiology 40: 231-237

Okuda N and Fujime Y, 1999. Effects of uniconazole and gibberellin treatment on flower bud formation of Chinese kale (Brassica oleracea $L$. var. alboglabra $L$. H. Bailey). Kagawa Daigaku Nogakubu Gakujutsu Hokoku. 51: 15-24.

Olivieri A M and Parrini P, 1979. Earliness of flowering in winter and summer rapeseed. Cruciferae Newsletter 4: 22-23

Olsson G, 1960. Some relations between number of seeds per pod, seed size and oil content and the effects of selection for these characters in Brassica and Sinapis. Hereditas, Lund 46: 29-70

Oosterom E J and Acevedo E, 1992. Adaptation of barley (Hordeum vulgare L.) to harsh Mediterranean environments. Euphytica 62: 29-38.

Palmer T P, 1958. Split petals in Cruciferae. Heredity 12: 417-428 
Paul V H, 1991. Pilzkrankheiten in Raps und deren Bekämpfung. In: Paul V H (ed.), Das Raps. DowElanco. pp : 123-141

Perez A E and Tena M, 1990. Purification and characterization of pectic enzymes from two races of Fusarium oxysporum f. sp. ciceri differing in virulence to chickpea (Cicer arietium L.) Phys. Mol. Plant Pathol. 37: 107-124

Pierre J, Pierre J S, Marilleau R, Pham-Delegue M H, Tanguy X and Renard M, 1996. Influence of the apetalous character in rape (Brassica napus) on foraging behaviour of honeybees (Apis mellifera). Plant Breed. 115: 484-487

Ponomarenko V, 1980. Clarification of the origin, systematics and morphology of apetalous apples. Plant Breed. Abstr. 52:9662

Rana M A, 1985. Development morphology of flower and inheritance of an apetalous mutant in Brassica carinata. Dissertation, University of California, Davis. Abstr. International. B (Science and Engineering) 45: 3425B

Rao M S S, Mendham N J and Buzza G C, 1991. Effect of the apetalous flower character on radiation distribution in crop canopy, yield and its components in oilseed rape (Brassica napus). J. Agricult. Sci., Cambridge. 117: 189-196

Rawat D S and Anand I J, 1986. Inheritance of flower color in mustard mutant. Indian J. Agricult. Sci. 56: 206-208

Renard M and Mesquida, 1987. Significance of nectar secretion for honeybee foraging Apis mellifera, and consequences on pollination in oilseed rape Brassica napus seed production. Proc. $7^{\text {th }}$ Int. Rapeseed Cong., Poznan, 1987, Poland. pp:222-227

Richiharia $\mathrm{R} \mathrm{H}, 1957$. Plant breeding with reference to oilseed crops. Indian J. Genet. 17: 218-247

Röbbelen G, 1997. The evolution of rapeseed quality. GCIRC Bulletin 14: 102-113

Seguin-Swartz G, 1988. Inheritance of pale yellow petal mutant of summer rape. Cruciferae Newsletter 13: 24-25 
Shirzadegan M and Röbbelen G, 1985. Influence of seed color and hull proportion on quality properties of seed in Brassica napus L.. Fette. Seifen. Anstrichmittel 6: 235-237

Singh D P, Hauhan S C, and Magnath K S, 1964. Inheritance of characters in $B$. juncea. Indian J. Genet. 24: 288-290

Singh D, 1961a. Heredity changes in the number of petals in Brown Sarson. Indian Oilseed J. 5: 190-193

Singh D, 1961b. An apeatlous mutant in toria brown sarson (Brassica campestris var. brown sarson) and its inheritance. Curr. Sci. 30: 62-63

Singh R and Tripathi N N, 1994. Assured method of inoculation and screening of Brassica spp. against Sclerotinia sclerotiorum (Lib) De Bary. Crop Research (Hisar) 8: 570-574

Singh $\mathrm{R} \mathrm{N}, 1974$. Note on the breeding behavior of a new silique mutant in rai (B. juncea (L.) Czern and Coss. Indian J. Agricult. Res. 8: 204

Sorochinskaya M A and Galkin F M, 1972. Male steriliy in linseed (Linumusitaitssimum L.). Plant Breed. Abstr. 46: 6418

Stiewe G. and Röbbelen G., 1994. Establishing cytoplasmic male sterility in Brassica napus by mitochondrial recombination with $B$. tournefortii. Plant Breeding 113: 294-304

Tengbe M A, 1990. Züchterische Nutzung von induzierten Mutanten bei Raps (Brassica napus L.) - veränderte Polyenfettsäure-Zusammensetzung und Blütenblattlosigkeit. Diss. Georg-August-Universität Göttingen. pp34-45

The Imperial Agricultural Research Institute New Delhi, 1945. Brassica oil crops. Scientific reports of the Imperial Agricultural Research New Delhi for the ended $30^{\text {th }}$ June. pp : 93

Thomson J R, Kaminski D A, Morrall R A A, Gugel R K, 1994. Survey of canola diseases in Saskatchewan. Canadian Plant Disease Survey 75: 137-141 
Thurling N, 1991. Application of the ideotype concept in breeding for higher yield in the oilseed brassicas. Field Crops Res. 26: 201-219

Tobutt K R, 1994. Combining apetalous parthenocarpy with columnar growth habit in apple. Euphytica 77: 51-54

Twengstrom E, Kopmans E, Sigvald R and Svensson C, 1998. Influence of different irrigation regimes on carpogenic germination of sclerotia of Sclerotinia sclerotiorum. J. Phytopathology 146: 10, 487-493

Utz H F, 1994. Analysis of multi-factor designs. Plabstat - A Computer Progam for Statistical Analysis of Plant Breeding Experiments. Universität Hohenheim, Stuttgart. pp: 22-27

Venglat S P and Sawhney V K, 1996. Benzylaminopurine induces phenocopies of floral meristem and organ identity mutants in wild-type Arabidopsis plants. Planta (Heidelberg) 198: 480-487

Vera C L, Woods D L and Downey R K, 1979. Inheritance of seed coat color in Brassica juncea. Can. J. Plant Sci. 59: 635-637

Vondrakova Z, KrekuleJ and Machackova I, 1998. Is the root effect on flowering of Chenopodium rubrum mediated by cytokinins? Journal of Plant Growth Regulation. 17: 115-119

Wahmhoff W, Hedke K, v Tiedemann A, Nitzsche O and Ulber B, 1998. Impact of crop rotation and soil cultivation on the development of pests and diseases of rapeseed Zeitschrift für Pflanzenkrankheiten und Pflanzenschutz 106: 57-73

Wirth $S \mathrm{~J}$ and Wolf $\mathrm{G} \mathrm{A}, 1990$. Dye-labled substrates for the assay and detection of chitinase and iysozyme activity. J. Microbiol. Methods 12: 197-205

Yang G S and Fu T D, 1990. The inheritance of Polima cytoplasmic male sterility in Brassica napus. Plant Breed. 104: 121-124

Yates D J and Steven M D, 1987. Reflection and absorption of solar radiation by flowering canopies of oil-seed rape (Brassica napus L.), J. of Agricult. Sci., 
Cambridge. 109: 495-502

Zaman M W, 1989. Inheritance of seed color in Brassica campestris. Sveriges Utsädesförenings Tidskrift. 99: 205-207

Zhou L C, 1994. Evaluation of rapeseed genotypes against sclerotinia sclerotiorum (Lib.) De Bary. Oil Crops of China. 94: 69-72

Zhou Y Y, Wu Z B, Liu Y Q, Yang Y, 1995. Mechanism of direct redifferentiation of flower bud from explant of Dianthus chinensis $L$. by cytokinin inducement. Acta Phytophysiologica Sinica 21: 209-214 


\section{SEPARATE MANUSCRIPTS}

\subsection{Inheritance of a mutant with apetalous flowers in oilseed rape (Brassica napus)}

L. Jiang ${ }^{1.2}$, H. C. Becker ${ }^{1}$

${ }^{1}$ Institute of Agronomy and Plant Breeding, Georg-August-University Göttingen, Von Siebold Straße 8, 37075 Göttingen, Germany; ${ }^{2}$ Institute of Crop Science, Zhejiang Academy of Agricultural Sciences, New Shiqiao Road 198, Hangzhou 310021, PR China

With 3 tables

\section{Abstract}

The inheritance of apetalous flowers in the mutant 'ap-Tengbe' was investigated. 'Ap-Tengbe' was crossed with the German cultivar 'Falcon'. The $\mathrm{F} 1$, both $\mathrm{BC} 1$ generations and their reciprocal forms, as well as the $\mathrm{F} 2$ were grown for investigation of Petalous Degree (PDgr) in field experiments at Göttingen, Germany in 1997/98 and at Hangzhou, China, in 1998/99. The reciprocal F2 population was grown only at Hangzhou in 1998/99. The apetalous character in 'ap-Tengbe' is regulated by an interaction of cytoplasmic genes and two pairs of nuclear genes. Completely apetalous flowers are only expressed in genotype with the 'ap' cytoplasm and two homozygous recessive genes.

Key words: mutagenesis - apetalous flower - Brassica napus - cytoplasmic effect

\section{Introduction}

One of the characteristics of the family Brassicaceae is the typical flower with four free petals. In oilseed Brassicas mutants were observed, which had increased petals, reduced petals or absolute no petal (apetalous) (Singh 1961a, b, Cours \& Williams 1977, Buzza 1983, Rana 1985, Lü \& Fu 1990, Fray et al. 
1997). Apetalous genotypes may be more effective in photosynthesis and reallocation of assimilates due to the removal of the yellow flower layer (Chapman 1984, Yates \& Steven 1987, Mendham et al. 1991, Fray et al. 1996). Moreover, apetalous types may avoid some diseases, especially rapeseed stem rot (Sclerotinia sclerotiorum) or downy mildew (Peronospora parastica) (Mc Lean 1958, Krüger 1975, Larmarque 1983). On young petals, ascospore adhesion, germination, penetration of the host and collapse of epidermal cells were observed by scanning electron microscopy. Myceliums on petals invade leaf tissues and then infect plants. In contrast, ascospores landing directly on leaf surfaces do not germinate (Jamaux et al. 1995).

The apetalous genotypes have different origins. Most of them were either discovered in nature, further stabilized by inbreeding (Singh 1961a \& 1961b; Buzza 1983; Lü \& Fu 1990), or created by crossing between related species and then improved for agronomic traits by backcrossing with the elite parent (Chen 1989, Malik et al. 1999). The inheritance of apetalous character depends on species and genotype. In Brassica rapa, it is controlled by a single recessive gene (Singh 1961a, b, Cours \& Williams 1977), and in Brassica carinata by two recessive genes modified by other genes (Rana 1985). Genotypes with apetalous flowers are best investigated in Brassica napus. In different sources for apetalous flowers, the inheritance was observed to be controlled by two recessive genes (Buzza 1983), four recessive genes (Lü \& Fu 1990), an epistatic interaction between recessive alleles at a pair of homologous loci, or interaction between alleles at three loci (Kelly et al 1995).

The objective of this paper is to investigate the inheritance of 'ap-Tengbe', a new source for apetalous flowers, which was identified in European winter oilseed rape after mutagenic treatment with EMS.

\section{Materials and Methods}

The apetalous mutant was induced with EMS-treatment of a low linolenic acid line at the Institute of Agronomy and Plant Breeding, Georg-August- University Göttingen. Among 17899 M2 plants one apetalous plant was found (Tengbe 1990). This mutant was selfed and selected for six generations before a line ('ap-Tengbe') with stable expression of apetalous trait was achieved. 
'Ap-Tengbe' is winter type of Brassica napus. Some of its leaves show chlorophyll deficiency and become white at young seedling stage.

'Ap-Tengbe' had been crossed with the German cultivar 'Falcon'. In spring 1997 crosses were made among 'ap-Tengbe', 'Falcon' and their F1 ('Falcon' $x$ 'ap-Tengbe') plants to produce reciprocal RF1 ('ap-Tengbe' × 'Falcon'), BC1-1 (F1 x 'ap-Tengbe'), BC1-2 (F1 x 'Falcon'), the reciprocal RBC1-1 ('ap-Tengbe' $x$ F1), reciprocal RBC1-2 ('Falcon' $\times$ F1) and F2 ('Falcon' $\times$ 'ap-Tengbe') generations. Further, in spring 1998 selfing of RF1 plants ('ap-Tengbe' $x$ 'Falcon') resulted in seeds of reciprocal RF2 population.

Except for RF2, the populations were field grown for observation at two environments on the experimental farm of the University Göttingen at 'Reinshof' in Germany 1997/98 and on the experimental farm of Zhejiang Academy of Agricultural Sciences at Hangzhou in China 1998/99. The RF2 population was observed only at Hangzhou in 1998/99. Normal local agronomic practices were applied at both sites.

Petalous Degree (PDgr) was calculated according to Buzza (1983):

$$
\operatorname{PDgr}(\%)=\left(\sum_{i=1} P_{i} / 4 N\right) \times 100
$$

with,

$\mathrm{P}_{\mathrm{i}}$ : the number of petals on the $\mathrm{i}$-th flower

$\mathrm{N}$ : total number of the flowers counted

At least 25 open flowers of each plant were counted for number of petals at initial flowering stage. The apetalous, intermediate and normal petalled genotypes are defined as PDgr between 0-10 \%, 10-90\% and 90-100\%, respectively. The accordance between expected and observed segregation was tested by Chi-Square test $(\chi 2)$. 
Table 7.1-1 Distribution (\% of total of plants) for Petalous Degree (PDgr) in two environments

\begin{tabular}{lccc|cccc}
\hline PDgr & \multicolumn{3}{c|}{ Göttingen 1997/98 } & \multicolumn{4}{c}{ Hangzhou 1998/99 } \\
\cline { 2 - 8 }$(\%)$ & BC1-1 & RBC1-1 & F2 & BC1 & RBC1 & F2 & RF2 \\
& $(n=139)$ & $(n=132)$ & $(n=334)$ & $(n=100)$ & $(n=99)$ & $(n=200)$ & $(n=202)$ \\
\hline ap (0-9) & 0.0 & 25.8 & 0.0 & 0.0 & 26.3 & 0.0 & 5.0 \\
i (10-20) & 1.4 & 3.0 & 0.0 & 2.0 & 1.0 & 0.0 & 1.5 \\
i (21-30) & 0.7 & 6.8 & 0.0 & 2.0 & 7.1 & 0.0 & 3.0 \\
i (31-40) & 2.2 & 0.8 & 0.6 & 1.0 & 1.0 & 0.5 & 1.5 \\
i (41-50) & 0.7 & 1.5 & 0.3 & 3.0 & 1.0 & 0.0 & 0.5 \\
i (51-60) & 3.6 & 6.1 & 0.3 & 3.0 & 7.1 & 0.0 & 0.5 \\
i (61-70) & 6.5 & 9.1 & 0.0 & 5.0 & 11.1 & 0.0 & 5.0 \\
i (71-80) & 3.6 & 15.2 & 1.2 & 4.0 & 16.2 & 2.0 & 6.4 \\
i (81-90) & 5.8 & 8.3 & 5.1 & 11.0 & 9.1 & 6.0 & 13.4 \\
np (91-100) & 75.5 & 23.5 & 92.5 & 69.0 & 20.2 & 91.5 & 63.4 \\
\hline
\end{tabular}

\footnotetext{
${ }^{1}$ ap: apetalous genotype; i: intermediate genotype; np: normal petalled genotype
} 


\section{Results}

Results from Göttingen and Hangzhou are given in Table 7.1-1. Some differences exist between the two locations in terms of percentage of plants assigned to each subgroup varying from $0-10 \%$ to $90-100 \%$. In general however, the results from the two locations agree with each other. At both locations, PDgr segregated in BC1-1, RBC1-1, F2 and RF2. The generations F1, RF1, BC1-2 and RBC1-2 were uniform with normal petals. Both at Göttingen and at Hangzhou, approximately one-fourth of the plants in BC1-1 had an intermediate number of petals and the rest had normal petal number. Around one-sixteenth of the plants in F2 had intermediate number of petals and the others were normal petalled. No true apetalous plants were found in $\mathrm{BC} 1-1$ and F2 population. The segregating patterns in RBC-1 or RF2 were different from their corresponding reciprocal forms indicating a cytoplasmic effect. At both sites, about 1:2:1 for apetalous, intermediate and normal petalled plants segregated in RBC1-1. The actual observed segregation ratio in RF2 was 10 apetalous, 64 intermediate and 128 normal petalled plants at Hangzhou.

The results suggest that the apetalous character in 'ap-Tengbe' is controlled by the interaction of cytoplasmic substance and two nuclear genes (Table 7.1-2). Normal petalled plants have normal cytoplasm $\left(C_{N}\right)$ and four alleles in nucleus coding normal petals $\left(P_{1} P_{1} P_{2} P_{2}\right)$, whereas the apetalous 'ap-Tangbe' mutant has apetalous cytoplasm $\left(C_{a p}\right)$ and four alleles coding the absence of petals $\left(p_{1} p_{1} p_{2} p_{2}\right)$. Alleles for petals are dominant to those for apetalous flowers. Accordingly, the F1 plants ('Falcon' $x$ 'ap-Tengbe') have $C_{N}$ and the nuclear genes $P_{1} p_{1} P_{2} p_{2}$, and shows normal petals. The RF1 plants ('ap-Tengbe' $x$ 'Falcon') have $C_{a p}$, but they still show normal petals due to dominant effect of both $P 1$ and $P 2$ alleles. In BC1-1 or F2 plants with $C_{N}$ in acting, which influences the expressing of apetalous character from $p_{1}$ or $p_{2}$, only the genotypes with of $p_{1} p_{1} p_{2} p_{2}$ are able to express a certain degree of apetalous character and the genotypes with three or less recessive alleles of $p_{1}$ and $p_{2}$ have normal petals. Therefore, segregations in $\mathrm{BC} 1-1$ and $\mathrm{F} 2$ populations are 0:1:3 and 0:1:15 respectively for apetalous, intermediate and normal petalled types. However, the RBC1-1 or RF2 plants with $C_{a p}$ cytoplasm show a segregation of 1:2:1 or 1:6:9 for apetalous, intermediate and normal petalled types, respectively. 
Because the BC1-2 and the RBC1-2 plants have either $C_{N}\left(P_{1_{-}}\right)$or $C_{N}($ $P_{2}$ ), they perform normal petalled phenotype. No true apetalous type can be found in these two populations. The genetic codes for various phenotypes are summarized in Table 7.1-2.

Chi-Square test $\left(\chi^{2}\right)$ shows that all observed segregations agree with the expected ratios (Table 7.1-3). Thus, we conclude that the apetalous character in 'ap-Tengbe' is regulated by interaction of cytoplasmic genes and two nuclear genes.

For one of the generations, the reciprocal RF2 ('ap-Tengbe' $x$ 'Falcon'), two alternative genetic interpretations are possible (Table 7.1-3). The actual observed segregation in RF2 population was 10:64:128 for apetalous, intermediate and normal petalled types. The theoretical segregation of 1:6:9 is based on the assumption that the genes are acting independently and additively. There exists another possibility, that the gene for normal petals is epistatically over the apetalous gene in the genotypes $C_{a p}\left(P_{1} P_{1} p_{2} p_{2}\right)$ or $C_{a p}\left(p_{1} p_{1} P_{2} P_{2}\right)$. Then the theoretical segregation in RF2 should be 1:5:10 for apetalous, partial apetalous and normal petalled phenotypes. According to Chi-square test both hypotheses are possible, however, the later hypothesis fits better to the actual observation.

\section{Discussion}

The genetic analysis of apetalous character in 'ap-Tengbe' was based on segregation of PDgr. The definition of PDgr in this study is different from Buzza (1983), who defined the intermediate type as of PDgr between 10 and $80 \%$ instead of 10 and $90 \%$ as we did. According to our field observation, even with PDgr of $80-85 \%$ some absolute apetalous flowers may still present on an inflorescence, whereas with PDgr of above $90 \%$, absolute apetalous flowers were extremely rare. 
Table 7.1-2 Genetic interpretations for apetalous, partial apetalous and normal petalled phenotypes

\begin{tabular}{lll}
\hline Type of Cytoplasm & Nuclear Genotype & Phenotype \\
\hline$C_{N}$ & $P_{1}--$ & Normal petalled \\
& $-P_{2}$ & Normal petalled \\
& $p_{1} p_{1} p_{2} p_{2}$ & Partial apetalous \\
& $P_{1}-P_{2}-$ & Normal petalled \\
$C_{a p}$ & $P_{1} p_{1} p_{2} p_{2}$ & Partial apetalous \\
& $p_{1} p_{1} P_{2} p_{2}$ & Partial apetalous \\
& $p_{1} p_{1} p_{2} p_{2}$ & Apetalous \\
& $P_{1} P_{1} p_{2} p_{2}$ & Normal or partial petalled \\
& $p_{1} p_{1} P_{2} P_{2}$ & Normal or partial petalled \\
\hline
\end{tabular}


Table 7.1-3 Chi-Square test $\left(\chi^{2}\right)$ for segregation of Petalous Degree (PDgr) in segregating populations grown at Göttingen or Hangzhou

\begin{tabular}{lllllll}
\hline \multicolumn{7}{c}{ Observed number } \\
\hline Populations & $\mathrm{ap}^{1}$ & $\mathrm{i}^{2}$ & $\mathrm{np}^{3}$ & Expected ratio & $\chi^{2}$ value & $\chi^{2} 0.05$ \\
\hline $\mathrm{BC} 1-1(\mathrm{Gö})^{4}$ & 0 & 34 & 105 & $0: 1: 3$ & 0.02 & 3.84 \\
$\mathrm{BC} 1-1(\mathrm{Ha})^{5}$ & 0 & 31 & 69 & $0: 1: 3$ & 1.42 & 3.84 \\
$\mathrm{RBC1} 1$ (Gö) & 34 & 67 & 31 & $1: 2: 1$ & 0.17 & 5.99 \\
RBC1-1 (Ha) & 26 & 53 & 20 & $1: 2: 1$ & 1.22 & 5.99 \\
F2 (Gö) & 0 & 25 & 309 & $1: 15$ & 0.67 & 3.84 \\
F2 (Ha) & 0 & 17 & 183 & $1: 15$ & 1.73 & 3.84 \\
RF2 (Ha) & 10 & 64 & 128 & $1: 6: 9$ or $1: 5: 10$ & 4.19 or 0.58 & 5.99 \\
\hline
\end{tabular}

${ }^{1}$ ap: apetalous genotype (PDgr<10); ${ }^{2}$ i: intermediate genotype (PDgr 10-90); ${ }^{3} \mathrm{np}$ : normal petalled genotype (PDgr $\left.>90\right) ;{ }^{4}$ Gö: grown at Göttingen 1997/98; ${ }^{5}$ Ha: grown at Hangzhou $1998 / 99$ 
The inheritance of apetalous flowers in 'ap-Tengbe' mutant resembles that of cytoplasmic male sterility (CMS) in the way that the cytoplasm interacts with nuclear genes in determining phenotypes (Yang \& Fu 1990, Stiewe et al. 1995, Delourme \& Budar 1999). It was recognized that CMS is often linked with small petals or a reduced petal number (Shiga 1980, McVettv et al. 1989). We also observed in 'ap-Tengbe' mutant a reduced pollen production (data not shown). Cytoplasmic effects on the inheritance of apetalous character have not been previously ascertained, although in Buzza's (1983), and Lü \& Fu's (1990) studies cytoplasmic effects were investigated. They made crosses between their apetalous materials and normal petalled parents and compared the reciprocal $\mathrm{F} 1$ and $\mathrm{F} 2$ populations without observing significant cytoplasmic effects. Rana (1985) investigated reciprocal crosses too, but his conclusion that no cytoplasmic effect existed was based merely on the observation of F1 and RF1 populations. Interactions of cytoplasmic genes and nuclear genes would not have been detected in Rana's design, because reciprocal F2 generations were not included. In all other studies on inheritance of apetalous trait cytoplasmic effect had not been taken into account.

In conclusion, the 'ap-Tengbe' mutant can be successfully used to develop completely apetalous breeding lines, but cytoplasmic effects have to be considered. The expression of the apetalous character was environmentally stable at two very different locations as Göttingen and Hangzhou. However, PDgr was always recorded at beginning of flowering. The influence of external and internal factors during flowering period on the expression of the apetalous phenotype will be communicated in a separate publication.

\section{Acknowledgements}

The authors thank Prof. G. Röbbelen and Dr. D. Stelling for developing and providing the 'ap-Tengbe' material, and Ms. D. Zhang for assisting in sowing and field observation at Hangzhou. The first author was financially supported by German Academic Exchange Services (DAAD). 


\section{Reference}

Buzza G. C., 1983. The inheritance of an apetalous character in Canola ( $B$. napus L.). Cruciferae Newsl. 8: 11-12

Chapman J. F., Daniels R. W., and Scarisbrick D H, 1984. Field studies on ${ }^{14} \mathrm{C}$ assimilate fixation and movement in oil-seed rape (B. napus). J. Agric. Sci., Cambridge. 102: 23-31

Chen B. Y., 1989. Apetalous flower. Resynthesized Brassica napus L.: A potential in breeding and research. Dissertation, The Swedish University of Agricultural Sciences, Svalöv. pp: 3-29

Cours B. J., and Williams P. H., 1977. Genetic studies in Brassica campestris L.. Plant Breed. Abstr. 51: 1533

Delourme R. and Budar F., 1999. Male sterility. In: Gómez-Campo C. (eds), Biology of Brassica Coenospecies, 185-216. Elsevier, Amsterdam.

Fray M. J., Evan E. J., Lydiate D. J. and Arthur A., 1996. Physiological assessment of apetalous flowers and erectophile pods in oilseed rape (Brassica napus). J. Agric. Sci., Cambridge, 127: 193-200

Fray M. J., Puangsomlee P., Goodrich J., Coupland G., Evans E. J., Arthur A. E. and Lydiate D. J., 1997. The genetics of stamenoid petal production in oilseed rape (Brassica napus) and equivalent variation in Arabidopsis thaliana. Theor. Appl. Genet. 94: 731-736

Jamaux L., Gelie B. and Lamarque C., 1995. Early stages of infection of rapeseed petals and leaves by Sclerotinia sclerotiorum revealed by scanning electron microscopy. Plant Pathology (Oxford) 44: 22-30

Kelly A., Fray M., Arthur E. A., and Lydiate D. J., 1995. The genetic control of 
petalless flowers and upright pods. Genetics and Methods. Proc. $9^{\text {th }}$ International Rapeseed Congress, Cambridge UK 1995. pp: 732-733

Krüger W., 1975. Die Beeinflussung der Apothezien- und AscosporenEntwicklung des Rapskrebserregers Sclerotinia sclerotiroum (Lib.) de Bary durch Umweltfaktoren. PflKrankh. 2: 101-108

Larmarque C., 1983. Conditions climatiques qui favorisent le processus naturei de ia contamination du colza par le Sclerotinia sclerotiorum. Proc. $6^{\text {th }}$ International Congress Paris France: 957-962

Lü Z. J. and Fu S. Z., 1990. Inheritance of apetalous character in Rape (Brassica napus L.) and its implication in breeding. Jiangshu J. Agricult. Sci. 6 (4): $30-36$

Malik M., Vyas P., Ranggaswamy N. S, Shivanna K. R., 1999. Development of two new cytoplasmic male-sterile lines in Brassica juncea through wide hybridisation. Plant Breed. 118: 75-78

Mc Lean D. M., 1958. Role of dead flower parts in infection of certain crucifers by Sclerotinia sclerotiorum (Lib.) De. Bary. Plant Disease Rep. 42: 663-666

McVetty P. B., Pinnisch R. and Scarth R., 1989. The significance of floral characteristics in seed production of four rape cultivar A-lines with pol cytoplasm. Can. J. Plant Sci. 69: 915-918

Mendham N. J., Rao M. S. S., and Buzza G. C., 1991. The apetalous flower character as component of a high yielding ideotype. GCIRC Congress. pp: 596-600

Rana M. A., 1985. Development morphology of flower and inheritance of an apetalous mutant in Brassica carinata. Dissertation, University of California, Davis. Abstr. International. B (Science and Engineering) 45 (11) 3425B 
Shiga T., 1980. Male sterility and cytoplasmic differentiation. In: Tsunoda S., Hinata K. and Gómez-Campo C. (eds), Brassica Crops and Wild Allies. 205-221. Jpn. Sci. Soc. Press, Tokyo

Singh D., 1961a. Heredity changes in the number of petals in Brown Sarson. Indian Oilseed J. 5 (3): 190-193

Singh D., 1961b. An apetalous mutant in toria brown sarson (Brassica campestris var. brown sarson) and its inheritance. Curr. Sci. 30: 62-63

Stiewe G. and Röbbelen G., 1994. Establishing cytoplasmic male sterility in Brassica napus by mitochondrial recombination with $B$. tournefortii. Plant Breeding 113: 294-304

Tengbe M. A., 1990. Züchterische Nutzung von induzierten Mutanten bei Raps (Brassica napus L.) - veränderte Polyenfettsäure-Zusammensetzung und Blütenblattlosigkeit. Dissertation, Georg-August-Universität Göttingen.

Yang G. S. and Fu T. D., 1990. The inheritance of 'Polima' cytoplasmic male sterility in Brassica napus. Plant Breed. 104: 121-124

Yates D. J. and Steven M. D., 1987. Reflection and absorption of solar radiation by flowering canopies of oilseed rape (Brassica napus L.), J. Agric. Sci., Cambridge. 109: 495-502 


\subsection{Environmental effects on expression of apetalous flowers in oilseed Rape (Brassica napus)}

L. Jiang ${ }^{1.2}$, H. C. Becker ${ }^{1}$

${ }^{1}$ Institute of Agronomy and Plant Breeding, Georg-August-University Göttingen, Von Siebold Straße 8, 37075 Göttingen, Germany; ${ }^{2}$ Institute of Crop Science, Zhejiang Academy of Agricultural Sciences, New Shiqiao Road 198, Hangzhou 310021, PR China

With 4 tables and 1 figure

\section{Abstract}

Apetalous genotypes may be of interest in oilseed rape breeding because of a more efficient photosynthesis and a lower susceptivity to pathogens infecting the petals. Petalous degree was, however, found unstable during flowering. Two types of environmental effects were investigated: (1) developmental stage of the flowers, and (2) application of different phytohormones. Materials used were (1) F1, BC1 and F2 generations developed from crosses between the German cultivar 'Falcon' and the apetalous mutant 'ap-Tengbe', and (2) double haploid $(\mathrm{DH})$ lines with apetalous, partial apetalous and normal petalled flowers developed by microspore culture of F1 plants ('ap-Renard' $\times$ 'ap-Tengbe'). It was observed (1) that petalous degree (PDgr) decreased from initial anthesis to end of flowering both in the partial apetalous and the normal petalled plants originating from the cross between 'Falcon' and 'ap-Tengbe'; and (2) that the supply of auxins or cytokinins resulted in reduction of PDgr in the partial or the normal petalled $\mathrm{DH}$ plants. The results suggest that the unstable expression of PDgr was caused by endogenetic accumulation of auxins or/and cytokinins at later flowering stages.

Key words: environmental effect - phytohormone - apetalous flower Brassica napus - mutation 


\section{Introduction}

Apetalous genotypes are of interest in oilseed rape (Brassica napus) breeding because of their more efficient photosynthesis and re-allocation of photosynthesized assimilates (Mendham et al 1981, Fray et al 1996, Jiang \& Becker in preparation) and their lower sensibility to some diseases distributed by petals, e.g. stem rot (Sclerotinia sclerotiorum) or downy mildew (Peronospora parastica) (Mc Lean 1958, Krüger 1975, Larmarque 1983, Jiang et al. in preparation). Different genetic sources for apetalous flowers have been described in literature (Buzza 1983, Rana 1985, Kelly et al. 1995, Frey et al. 1997, Jiang \& Becker in preparation). The expression of apetalous flowers was sometimes found to be influenced by environmental conditions. Petalous degree (PDgr) was either decreasing (Liu 1985, Tengbe 1990) or increasing (Chen 1989) from initial anthesis to later flowering stages.

In all Brassica species, the development of sepals, androecium and gynoecium is simutaneously, and the initiation of the corolla is the last stage. The development of apetalous and petalous types is similar until corolla initiation (Rana 1985). Petal development appears to be in delicate balance with the internal and external environment. Endogenous phytohormone concentration may be important in the process of floral organ initiation and differentiation. Such hormones include cytokinins and auxins (Davies 1987, Metzger 1987). The involvement of cytokinins in floral organ formation and development were recognized in tomato (Lycopersicon esculentum) (Mennary and Staden 1976, Kaur et al. 1996), in Hyacinthus orientalis (Lu et al. 1994), in Dianthus chinensisi L. (Zhou et al. 1995), in Chenopodium rubrum (Vondrakova et al. 1998) and in Polianthes tuberosa (Chang et al. 1999). Auxins' significant activities in differentiation and the formation of floral meristem were determined in the early growth stage in Bougainvillea glabra L. (Awad et al. 1988), in Tanacetum cinerariaefolium L. (Brown \& Menary 1994). Some other hormones or substances may also have certain influences on floral organ differentiation and development, these include, gibberellin (Okuda \& Fujime 1999) and phosphorus (Menary \& Staden 1976).

Application of exogenous hormones may disrupt the balance of plant endogenous hormones and thus influence the process of floral organ 
differentiation and development.

No quantitative information on PDgr changes due to environment and on effects of hormone on the expression of PDgr is available for Brassicas in literature. The objectives of our study are (1) to describe changes of PDgr during flowering in materials with apetalous genetic background in the field; and (2) to investigate the effect of application of cytokinins and auxins on the expression of PDgr in double haploid (DH) plants with apetalous, partial or normal petalled flowers.

\section{Material and methods}

(1) The definition of PDgr

PDgr was defined and calculated according to Buzza (1983). More than 25 open flowers on one plant were counted for number of petals for each date of an observation.

$$
\operatorname{PDgr}(\%)=\left(\sum_{i=1} P_{i} / 4 N\right) \times 100 \%
$$

with,

$P_{i}$ : The number of petals on the i-th flower;

$\mathrm{N}$ : Total number of the flowers counted

(2) Changes of PDgr during flowering in the field

Observed were plants of $\mathrm{F} 1, \mathrm{BC} 1, \mathrm{~F} 2$ generations and their respective reciprocal forms, developed from crosses between the German winter oilseed rape cultivar 'Falcon' and apetalous mutant 'ap-Tengbe'. The apetalous parent was a mutant induced with EMS-treatment at Institute of Agronomy and Plant Breeding, Georg-August-University Göttingen (Tengbe 1990). It had been selfed and selected for six generations for stable expression of apetalous flowers.

The above plant materials were grown at Göttingen, North Germany in 1997/98 and at Hangzhou, Southeast China in1998/99. PDgr was recorded at initial anthesis, during 27 April to 3 May 1998 at Göttingen or 25 March to 2 April 1999 at Hangzhou, and at later flowering stage, during 12 May to 15 May 1998 at Göttingen or 17 April to 22 April at Hangzhou, on a same plant. Between 16 and 20 plants in the non-segregating populations (F1, RF1) and 50 plants in the 
segregating populations ( $\mathrm{BC} 1, \mathrm{RBC} 1, \mathrm{~F} 2$ and $\mathrm{RF} 2$ ) were labeled and scored at the two dates.

Paired comparisons of PDgr values that obtained on the two dates were made. Statistical significance was tested by appropriate $\mathrm{t}$-tests.

(3) Effect of hormones on expression of PDgr

\section{Plant material:}

The French apetalous genotype 'ap-Renard' was crossed with 'ap-Tengbe'. F1 plants were normal petalled. DH lines with apetalous, partial apetalous and normal petalled flowers were developed by microspore culture. 2 apetalous(DH3-3, DH3-7), 1 partial apetalous- (DH2-3) and 3 normal petalled (DH1-1, DH1-2 and DH2-2) lines were selected for the field experiment after being multiplied in greenhouse in 1999.

Method of microspore culture and DH plant development:

About 30-40 young flower buds in size of 3-5 mm were collected from upper racemes of the $\mathrm{F} 1$ plants grown in greenhouse. Surface sterilized with $\mathrm{CaCl}_{2} \mathrm{O}_{2}$ solution, they were then macerated for extraction of microspores. The extracted microspores were centrifuged and then suspended in $10 \mathrm{ml}$ Lichter medium (Lichter 1982) plus $100 \mathrm{\mu g}$ colchicin. The suspension was incubated at $32^{\circ} \mathrm{C}$ for 72 hours and then recentrifugated, washed and resuspended in fresh Lichter medium. The new suspension was plated on gyratory shaker and maintained incubation in dark at about $22-25^{\circ} \mathrm{C}$. Approximately 120 embryos had formed in about 35 days. They were replenished with fresh Lichter medium and were not transferred on solid medium until more than about $2-3 \mathrm{~cm}$ in length.

\section{Design of the field experiment}

Randomised complete blocks were designed with hormone and genotype as two factors. The following hormone solutions were used: $100 \mathrm{ppm}$ indoleacetic acid (IAA) (Serva Feinbiochemica), 20 ppm kinetin (Sigma-Aldrich Chemie Gmbh), 100 ppm 2,4-D (Sigma-Aldrich Chemie Gmbh), 100 ppm mixed Naphthaleneacetic acid (NAA) and Benzylaminopurine (BA) (NAA:BA=4:1) (Serva Feinbiochemica), 20 ppm Benzylaminopurine (BA) and water as control. 10 litres of each solution were evenly distributed on $6 \mathrm{DH}$ lines in two replications. $20 \mathrm{ml}$ Folicur (Bayer) was mixed thoroughly in each 10 liter 
solution before the application. The fungicide was used as adhesive to ensure a longer hormone effect on young flower buds and leaves.

The solutions were sprayed on the $\mathrm{DH}$ plants about 8-14 days before anthesis.

\section{Method of investigation and statistics}

PDgr score is the average of 4 plants observed in each plot. Numbers of affected (N1) and unaffected racemes (N2) of a plant were counted. The reduction of PDgr on affected racemes (R1) and the reduction of PDgr of a whole plant (R2) after the application of hormones were estimated according to the following equations:

$R 1=P D g r_{C K}-P D g r 1$

$R 2=P D g r_{C K}-P D g r 2$

$P D g r 2=(P D g r 1 \times N 1+P D g r 3 \times N 2) /(N 1+N 2)$

with,

$P D g r_{C K}$ : PDgr of a genotype without the application of hormones

PDgr1: PDgr of affected racemes on observed plants after hormone application PDgr2: PDgr of an observed whole plant

PDgr3: PDgr of unaffected racemes on observed plants after hormone application

PLABSTAT (Utz 1994) ANOVA of R1, R2 and N1 was performed to estimate least significant difference (LSD).

\section{Results}

(1) Changes of PDgr during flowering in the field

PDgr changes from initial anthesis to end of flowering in two environments are given in Table 7.2-1. Average PDgr decreased from initial anthesis to end of flowering in all populations. Significance tests on paired observations revealed that the reductions of PDgr in F1 population were not significant at both locations and the reductions of PDgr in RF1, BC1, RBC1 populations were significant at $1 \%$ level at both locations. In respect of significance of PDgr reduction, the results drawn from the both locations were congruent with each other in most populations except for F2, where significant reduction of PDgr was only found at Hangzhou in 1999. 
In general, relative larger reductions of PDgr were found in plants from the reciprocal crosses, where the apetalous mutant 'ap-Tengbe' served as maternal parent. Considerable reductions of PDgr were found in $\mathrm{RBC} 1$ population either at Göttingen in 1998 or at Hangzhou in 1999, where $25.7 \%$ or $12.4 \%$ reduction of PDgr was scored, respectively. Relatively large reductions of PDgr were also found in RF1 (15.0\% and 13.3\% for Göttingen and Hangzhou).

Larger reductions of PDgr were scored at Göttingen in 1998 compared to Hangzhou in 1999 in most populations with exception in BC1.

Figure 7.2-1 A typical raceme affected by application of the hormones

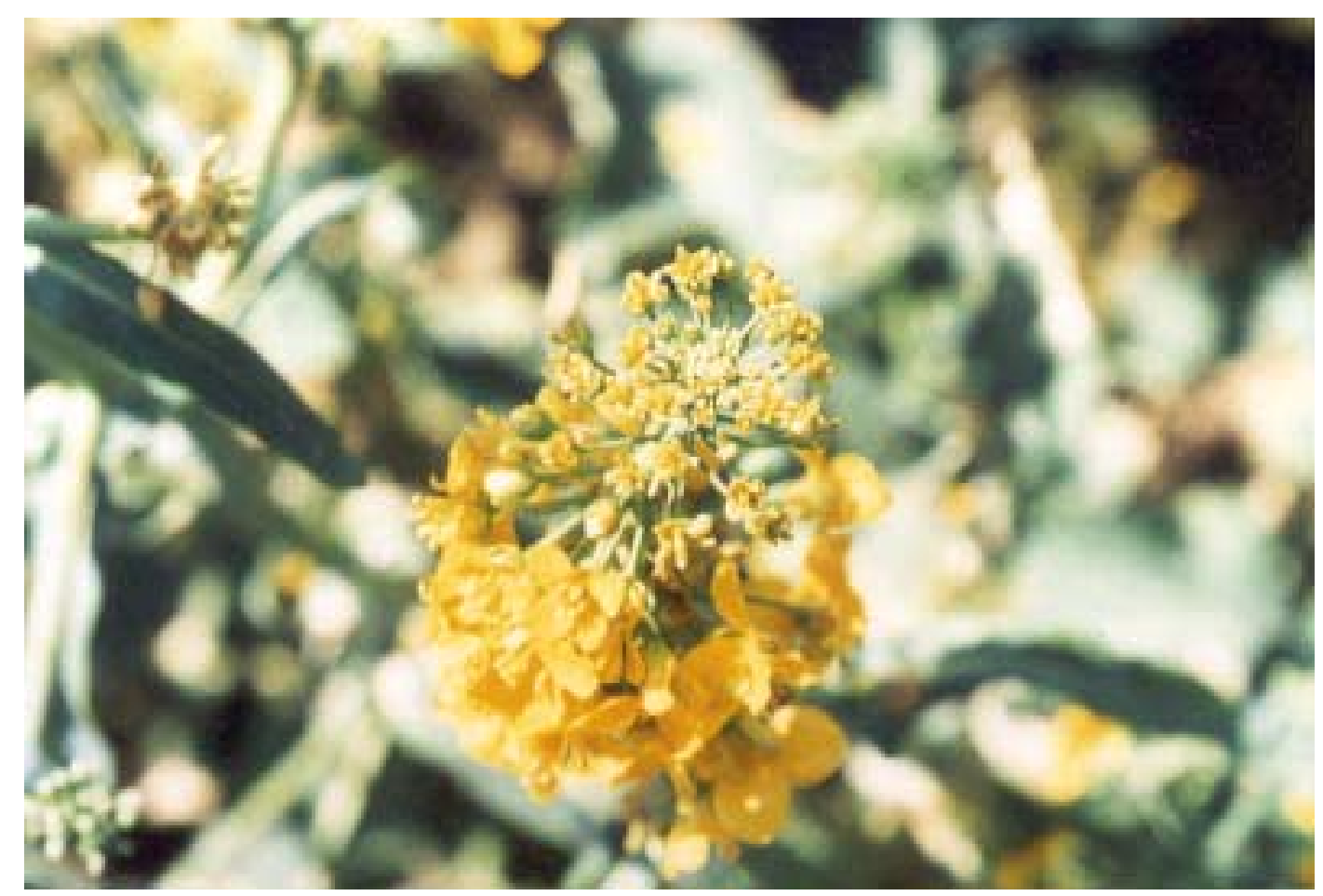

(2) Effect of hormones on expression of PDgr

The application of 2,4-D solution and the mixed BA and NAA solution in concentration of $100 \mathrm{ppm}$ led to entirely ceasing of vegetative growth in some plots. The data obtained for these two treatments were therefore incomplete and will not be reported. The application of IAA, kinetin and BA on flower buds and leaves affected about 6-10 racemes on a plant. The affected racemes were recognized either by PDgr changes or by malformation of inflorescence. Figure 7.2-1 shows typical racemes affected by application of the hormones. 
Apetalous flowers appeared very often on top of an inflorescence. They were smaller than the normal flowers. Their stamens produced much less pollen or in some cases disappeared completely. There was not much difference for morphological appearance among the apetalous flowers induced by the different types of hormones.

PDgr1 and PDgr2 decreased both in the normal petalled genotypes and in the partial apetalous genotype, but they remained unchanged $(P D g r=0)$ in the apetalous genotypes after application of the hormones. R1 or R2 of the sprayed plants varied in the range of $45.9-63.4 \%$ or $15.4-29.8 \%$ in the normal petalled genotypes, compared with $28.8-36.3 \%$ or $9.9-14.1 \%$ in the partial apetalous genotype, indicating that the applied hormones had larger influence on the normal petalled genotypes than on the partial apetalous genotype, and they had no influence on the apetalous genotypes on PDgr (Table 7.2-2 and Table 7.2-3).

ANOVA of R1 revealed that the effects of genotype and the interaction between hormone type and genotype were significant at $1 \%$ level. The largest R1 (63.40) was achieved when BA had been applied to the DH1-1 with normal flowers and the least R1 (0) was observed when any kind of hormones had been applied to the apetalous genotypes. No significant difference among the hormone types was determined for R1, although the application of the cytokinins, BA and kinetin, had stronger effects than the application of IAA. On the other hand, genotype effect was significant, but the differences within the flower types were not significant (Table 7.2-2).

Effects of genotype and interaction of genotype and hormone type were significant at $1 \%$ level for R2. The largest R2 (29.75) was achieved by the application of kinetin on DH2-2 and the lowest R2 (0) was observed by the application of any kind of hormones to the apetalous types. There was no significant difference among the hormone types in terms of their effects on R2, though BA and kinetin performed stronger effects than IAA. The normal petalled DH1-1 and DH2-2 responded to the hormone applications with significantly larger R2 value than the partial apetalous DH2-3. No significant difference was detected within flower types as well as between the normal petalled DH1-2 and the partial apetalous $\mathrm{DH} 2-3$ in respect of their $\mathrm{R} 2$ in response to the application of hormones (Table 7.2-3). 
Table 7.2-1 ANOVA of paired PDgr data scored on same plants at initial anthesis and end of flowering in two environments

\begin{tabular}{|c|c|c|c|c|c|c|}
\hline & $\mathrm{F} 1$ & $\mathrm{RF} 1$ & $\mathrm{BC} 1$ & RBC1 & $\mathrm{F} 2$ & RF2 \\
\hline PDgr (initial anthesis) - Göttingen 1998 & 99.6 & 97.1 & 89.7 & 54.9 & $76.1^{a}$ & - \\
\hline PDgr (end flw.) - Göttingen 1998 & 98.7 & 82.2 & 82.0 & 29.2 & $70.6^{a}$ & - \\
\hline PDgr (initial anthesis) - Hangzhou 1999 & 99.8 & 98.3 & 84.5 & 48.6 & 99.5 & 85,3 \\
\hline PDgr (end flw.) - Hangzhou 1999 & 94.4 & 85.3 & 72.3 & 36.1 & 95.3 & 77.7 \\
\hline N - Hangzhou 1999 & 20 & 20 & 50 & 50 & 50 & 50 \\
\hline t - Göttingen 1998 & 0.67 & $3.40^{* *}$ & $4.18^{\star \star}$ & $6.67^{\star \star}$ & 1.14 & - \\
\hline t - Hangzhou 1999 & 2.00 & $8.86^{\star \star}$ & $6.78^{\star *}$ & $4.96^{\star *}$ & $3.50 * *$ & $4,47^{\star \star}$ \\
\hline
\end{tabular}

${ }^{a}$ investigation made only on partial apetalous plants; ${ }^{b}$ number of observed plants; ${ }^{* *}$ significant at $1 \%$ level; ${ }^{*}$ significant at $5 \%$ level 
Table 7.2-2 Effect of the hormones on reduction of PDgr on the racemes affected by hormone application (R1) (\%)

\begin{tabular}{lllll}
\hline & IAA & kinetin & BA & Mean \\
\hline DH1-1 & 47.20 & 55.30 & 63.40 & 55.30 \\
DH1-2 & 52.95 & 57.80 & 53.80 & 54.85 \\
DH2-2 & 45.90 & 57.75 & 52.45 & 52.03 \\
DH2-3 & 28.80 & 32.75 & 36.35 & 32.63 \\
DH3-3 & 0.00 & 0.00 & 0.00 & 0.00 \\
DH3-7 & 0.00 & 0.00 & 0.00 & 0.00 \\
Mean & 29.14 & 33.93 & 34.33 & 32.47 \\
\hline
\end{tabular}

The effects of genotype and the interaction between genotype and hormone type were significant; $L S D(G)_{0.05}=6.89$

Table 7.2-3 Effect of the hormones on reduction of PDgr of whole plants (R2) (\%)

\begin{tabular}{lllll}
\hline & IAA & Kinetin & BA & Mean \\
\hline DH1-1 & 19.75 & 22.55 & 25.70 & 22.67 \\
DH1-2 & 16.50 & 15.40 & 22.15 & 19.02 \\
DH2-2 & 17.50 & 29.75 & 19.45 & 22.23 \\
DH2-3 & 9.85 & 14.10 & 14.05 & 12.67 \\
DH3-3 & 0.00 & 0.00 & 0.00 & 0.00 \\
DH3-7 & 0.00 & 0.00 & 0.00 & 0.00 \\
Mean & 10.60 & 13.63 & 14.06 & 12.76 \\
\hline
\end{tabular}

The effects of genotype and the interaction between genotype and hormone type were significant; $L S D(G)_{0.05}=6.58$

Table 7.2-4 Effect of the hormones on number of affected racemes with PDgr changing (N1)

\begin{tabular}{llllll}
\hline & IAA & Kinetin & BA & CK & Mean \\
\hline DH1-1 & 8.40 & 8.15 & 8.50 & 0.00 & 6.26 \\
DH1-2 & 7.75 & 7.40 & 8.55 & 0.00 & 5.93 \\
DH2-2 & 7.90 & 7.90 & 8.25 & 0.00 & 6.01 \\
DH2-3 & 7.30 & 7.75 & 8.15 & 0.00 & 5.80 \\
Mean & 7.84 & 7.80 & 8.36 & 0.00 & 6.00 \\
\hline
\end{tabular}

The effect of hormone type was significant; $L S D(H)_{0.05}=0.40$ 
By ANOVA for N1, only the effect of hormone type was found significant at $1 \%$ level, while the effects of genotype and interaction between genotype and hormone type were not significant. The application of BA resulted in the highest $\mathrm{N} 1$ (8.36 in average), which was significantly larger than that caused by the application of IAA or kinetin (7.84 or 7.80). No significant difference was found between IAA and kinetin in their effects on N1 (Table 7.2-4).

\section{Discussion}

Our first experiment clearly shows that PDgr changes at different developmental stages during flowering. It decreased at later flowering stage in different environments with different extent. A Larger reduction of PDgr was observed at Göttingen than at Hangzhou in most populations. The explanation could be that larger amounts of phytohormones like auxins or/and cytokinins would have been synthesized at later flowering stage in external conditions under the environmental in Göttingen.

Some factors could affect the outcome of the second experiment, which was aimed at the induction of PDgr changes by phtohormones. A successful induction could depend on: (1) type of hormones chosen; (2) growth stage of the plants when hormones were applied; (3) concentration of hormone solution. Several cytokinins and auxins were used for the experiment, as their activities and changes throughout flowering were reported to be important in the terminal buds and young flowers (Oka et al. 1998, 1999, Chang et al. 1999). Growth stage at 8-14 days before anthesis was chosen for the unique application that resulted in 6-10 affected racemes. More affected racemes might have been achieved by repeating the application until after flowering. The mixture of the hormone solutions with the fungicide (Folicur) seemed to be an effective measure to prolong the effect of hormones on flower buds and leaves. However, to choose appropriate concentration of a hormone was more difficult, because it relies on the sensitiveness and uptake efficiency of a plant at a certain developmental stage. By spraying, $10^{-3}-200 \mathrm{ppm}$ and $10^{-5}-100 \mathrm{ppm}$ in concentration were suggested for auxin and cytokinin, respectively, aiming at a positive interference on vegetative growth (Davies 1987, Metzger 1987). Our study showed that the application of 2,4-D and the mixed BA and NAA solutions 
in concentration of $100 \mathrm{ppm}$ was too high for vegetative and reproductive development at growth phase 8-14 days before anthesis in oilseed rape.

The apetalous character in 'ap-Tengbe' is controlled by two recessive nuclear genes $\left(p_{1} p_{1} p_{2} p_{2}\right)$ co-functioning with cytoplasmic gene $\left(C_{a p}\right)$ (Jiang \& Becker in preparation). The present study further demonstrated that more reduction of PDgr took place during flowering in plants from the reciprocal crosses. These plants had abnormal cytoplasmic genes $\left(C_{a p}\right)$. It would be possible that the apetalous $(\mathrm{PDgr}=0)$ or less petalous character $(\mathrm{PDgr}<90)$ was caused by excessive synthesis of endogenous cytokinin or/and auxin and perhaps other kinds of hormones in plant cells at flowering phase catalyzed by the two recessive and cytoplasmic genes that acted additively. The malfunction of the genes would be probably caused by point mutation induced by chemical treatment.

There is only very limited information available was not much information about hormones' role in formation and differentiation of floral organs in Brassica napus. However, as Brassica napus and Arabidopsis thaliana are both members of the Brassicaceae and the genomes of Brassica and Arabidopsis are collinear, information on the regulatory genes that control and coordinate the determination, differentiation and morphophogenesis of the floral meristem and floral organs in Arabidopsis thaliana (Oka et al. 1998, 1999) may be used as reference to Brassica napus. In Arabidopsis thaliana, it was found that application of BA to inflorescences at certain developmental stages resulted in increase in floral organ number, formation of abnormal floral organs as well as induction of secondary floral buds in the axils of sepals. Venglat et al. (1996) explained that exogenous BA suppresses the normal functioning of the genes for floral meristem identity and thereby affects flower development and the later stages of floral organ differentiation. In our experiment, increases in floral organ number and induction of secondary floral buds in the axils of sepals were not observed.

In conclusion, PDgr in the plants with apetalous gene(s) changes during flowering stage in Brassica napus. The decomposing or accumulation of the endogenetic hormones as auxin or cytokinin is responsible for the changes of PDgr. Nevertheless, genotypes with absolutely stable expression of apetalous 
flowers (PDgr=0) can be selected.

\section{Acknowledgement}

The authors thank Dr. C. Möllers for advice in microspore culture and Mrs. S. Rummelsberger, Mr. G. Miotke and Mr. A. Henn for technical assistance in field and greenhouse work. The first author was financial supported by Prof. Werner Schultze Stiftung and Forschungs- und Entwicklungsfond Raps. 


\section{ZUSAMMENFASSUNG}

\section{Wirkung von Umweltfaktoren auf die Ausprägung der Blütenblätter bei Raps}

\section{(Brassica napus)}

Blütenblattlose Genotypen sind wegen ihrer leistungsfähigeren Photosynthese, sowie ihrer geringeren Anfälligkeit gegenüber Krankheitserregern, welche durch die Blütenblätter übertragen werden, von Interesse für die Rapszüchtung. Die Anzahl ausgebildeter Blütenblätter war jedoch unstabil im Verlauf der Blühperiode. Zwei unterschiedliche Umweltfaktoren wurden untersucht: (1) Entwicklungsstadium der Blüten, und (2) Anwendung unterschiedlicher Phytohormone. Das untersuchte Materialen umfaßte: (1) die durch Kreuzung zwischen 'Falcon' und 'ap-Tengbe' entstandenen F1, BC1 und F2 Generationen and (2) doppelhaploide (DH) Linien mit blütenblattlosen, halb blütenblattlosen und normale Blüten, die durch Mikrosporenkultur der von F1 ('ap-Renard' $\times$ 'ap-Tengbe') entwickelt wurden. Es wurde beobachtet, daß (1) die Anzahl an Blütenblättern je Blüte von Beginn der Blühperiode bis zum Blühende abnahm, und (2) die Reduktion der Blütenblätt durch endogene Anreicherung der Auxine oder/und der Cytokinine während der Blühphase verursacht wurde. 


\section{Reference}

Awad A, Dawh AK and Attya M, 1987. Cutting thickness and auxin affecting the rooting and consequently the growth and flowering of Bougainvillea glabra $L$. Acta Horticulturae 2: 445-454

Brown P H and Menary R C, 1994. Flowering in pyrethrum (Tanacetum cinerariaefolium L.). II. Changes in plant growth regulator concentrations. Journal of Horticultural Science 69: 985-992

Buzza G C, 1983. The inheritance of an apetalous character in Canola ( $B$. napus L.). The $4^{\text {th }}$ Australian Rapeseed Agronomists and Breeders Research Workshop 1983: 15-16

Chang S T, Chen W S, Hsu C Y, Yu H C, Du B S and Huang K L, 1999. Changes in cytokinin activities before, during and after floral initiation in Polianthes tuberosa. Plant Physiology and Biochemistry 37: 679-684.

Chen B Y, 1989. Apetalous flower. Resynthesized Brassica napus L.: a potential in breeding and research. Diss., the Swedish University of Agricultural Sciences, Svalöv. pp: 3-29

Davies P J, 1987. The phytohormones: Their nature, occurrence, and functions. In: Davies P J (eds.), Phytohormones and their role in plant growth and development. Martinus Nijhoff Publishers. pp: 5

Fray M J, Evan E J, Lydiate D J and Arthur A, 1996. Physiological assessment of apetalous flowers and erectophile pods in oilseed rape (Brassica napus). J. Agric. Sci., Cambridge, 127: 193-200

Fray M J, Puangsomlee P, Goodrich J, Coupland G, Evans E J, Arthur A E and Lydiate D J, 1997. The genetics of stamenoid petal production in oilseed rape (Brassica napus) and equivalent variation in Arabidopsis thaliana. Theor. Appl. 
Genet. 94: 731-736

Kaur S R, Applewhite P B and Galston A W, 1996. Formation in vitro of ripe tomato fruits from thin layer explants of flower pedicels. Plant Growth Regulation 18: 191-199

Kelly A, Fray M, Arthur E A and Lydiate D J, 1995. The genetic control of petalless flowers and upright pods. Genetics and Methods. Proc. $9^{\text {th }}$ International Rapeseed Congress, Cambridge UK 1995. pp: 732-733

Krüger W, 1975. Die Beeinflussung der Apothezien- und AscosporenEntwicklung des Rapskrebserregers Sclerotinia sclerotiorum (Lib.) de Bary durch Umseltfaktoren. Pfl. Krankh. 2, 101-108

Larmarque C, 1983. Conditions climatiques qui favorisent le processus naturei de ia contamination du colza par le Sclerotinia sclerotiorum. Proc. $6^{\text {th }}$ International Congress Paris France: 957-962

Lichter R, 1982. Induction of haploid plants from isolated pollen of Brassica napus. Z. Pflanzenphysiol. 105: 427-434

Liu H L, 1985. Remote crossing. In: Liu H L (ed.), Genetics and Breeding of Rapeseed, Shanghai Publishing House for Science and Technical Literatures, Shanghai. pp: 87-119

Lu W L, Liang B, Enomoto K and Fukunaga Y, 1994. Role of exogenous hormones in inducing cells in different positions of perianth explants to regenerate flower buds in Hyacinthus orientalis. Acta Botanica Sinica 36: 581-586

Mc Lean D M, 1958. Role of dead flower parts in infection of certain crucifers by Sclerotinia sclerotiorum (Lib.) De. Bary. Plant Disease Rep. 42: 663-666 
Medham N J, Shipway P J and Scott R K, 1981. The effect of delayed sowing and weather on growth, development and yield of winter oil-seed rape (Brassica napus). J. Agricult. Sci., Cambridge 96: 389-416

Menary R C and Staden J V, 1976. Effect of phosphorus nutrition and cytokinins on flowering in the tomato, Lycopersicon esculentum Mill. Australian Journal of Plant Physiology 3: 201-205

Metzger D J, 1987. Hormones and reproductive development. In: Davies P J (eds.), Phytohormones and their role in plant growth and development. Martinus Nijhoff Publishers. pp: 443-450

Oka M, Miyamoto K, Okada K and Ueda J, 1999. Auxin polar transport and flower formation in Arabidopsis thaliana transformed with indoleacetamide hydrolase (iaaH) gene. Plant and Cell Physiology 40: 231-237

Oka M, Ueda J, Miyamoto K and Okada K, 1998. Activities of auxin polar transport in inflorescence axes of flower mutants of Arabidopsis thaliana: Relevance to flower formation and growth. Journal of Plant Res. 111: 407-410

Okuda N and Fujime $\mathrm{Y}, 1999$. Effects of uniconazole and gibberellin treatment on flower bud formation of Chinese kale (Brassica oleracea $L$. var. alboglabra $L$. H. Bailey). Kagawa Daigaku Nogakubu Gakujutsu Hokoku 51: 15-24

Rana M A, 1985. Development morphology of flower and inheritance of an apetalous mutant in Brassica carinata. Diss., University of California, Davis. Abstr. International. B (Science and Engineering) 45: 3425B

Tengbe M A, 1990. Züchterische Nutzung von induzierten Mutanten bei Raps (Brassica napus L.) - veränderte Polyenfettsäure-Zusammensetzung und Blütenblattlosigkeit. Diss. Goerg-August-Universität Göttingen. pp34-45

Utz H F, 1994. PLABSTAT (Version 2H(L)), Ein Computerprogramm für 
statistische Analysen von Pflanzenzüchtungsexperimenten. Universität Hohenheim

Venglat S P and Sawhney V K, 1996. Benzylaminopurine induces phenocopies of floral meristem and organ identity mutants in wild-type Arabidopsis plants. Planta (Heidelberg).198: 480-487

Vondrakova Z, KrekuleJ and Machackova I, 1998. Is the root effect on flowering of Chenopodium rubrum mediated by cytokinins? Journal of Plant Growth Regulation 17: 115-119

Zhou Y Y, Wu Z B, Liu Y Q and Yang Y, 1995. Mechanism of direct redifferentiation of flower bud from explant of Dianthus chinensis $L$. by cytokinin inducement. Acta Phytophysiologica Sinica 21: 209-214 


\subsection{Effect of apetalous flowers on crop physiology in winter oilseed rape} (Brassica napus)

\section{Einfluß der Blütenblattlosigkeit auf die Ertragsphysiologie von Winterraps}

(Brassica napus)

L. Jiang and H. C. Becker

Institut für Pflanzenbau und Pflanzenzüchtung, Georg-August-University Göttingen, Von-Siebold-str. 8, D-37075 Göttingen, Geramny

\section{Summary}

The transmission of radiation to the leaf canopy of oilseed rape is reduced during flowering by the highly reflective yellow floral layer. Apetalous types may show a higher light assimilation and an increased yield. Crop physiology of a genetically apetalous line was compared with a partial apetalous and a normal petalled sister line. Field experiments were grown at three plant densities and three nitrogen levels at two locations in Northern Germany. The results show that (1) petals largely reduce the transmission of photosynthetically active radiation to the upper leaves, (2) petals have negative effects on leaf area index and duration of active green leaves, (3) petals have negative effects on weight of total biomass, (4) nevertheless petals have no negative effect on grain yield, oil content or protein content. The apetalous mutant had a lower harvest index than the normal sister line. It is concluded, that light transmission and leaf area during flowering are not yield limiting under the conditions investigated.

Key words: Brassica napus, apetalous flower, crop physiology, photosynthesis, leaf area index

\section{Zusammenfassung}

Die Lichteinstrahlung auf die Laubblätter wird beim Raps während der Blüte durch Reflexion der Blütenblätter reduziert. Daher könnte eine Reduktion der Blütenblätter zu einem Ertragsanstieg führen. Die Ertragsbildung einer genetisch blütenblattlosen Linie wurde verglichen mit einer 
halb-blütenblattlosen und einer normalen Geschwisterlinie. Die Feldversuche wurden mit drei Bestandesdichten und drei Stickstoffstufen an zwei Orten in Norddeutschland durchgeführt. Die Ergebnisse ergaben, daß die Blütenblätter (1) die Lichteinstrahlung auf die oberen Laubblätter stark reduzieren, (2) zu geringerem Blattflächenindex und kürzerer Blattflächendauer führen, (3) sich negativ auf die Gesamttrockenmasse auswirken, (4) aber dennoch keinen ungünstigen Einfluß auf Samenertrag sowie Öl- und Proteingehalt haben. Die blütenblattlose Mutante hatte einen niedrigeren Ernteindex als die normale Geschwisterlinie. Offenbar waren Lichteinstrahlung und die Blattfläche während der Blüte unter den untersuchten Umweltbedingungen nicht limitierend für die Ertragsbildung.

Schlüsselworte: Brassica napus, Blütenblattlosigkeit, Ertragsphysiologie, Photosynthese, Blattflächenindex

\section{Introduction}

Yield improvement is still the main objective in oilseed rape breeding, although improving oil and meal quality becomes more and more important (RÖBBELEN 1997, BECKER et al. 1999). One effective strategy for yield improvement might be to look for an ideal morphological type ('ideotype'). Several morphological and agronomic traits have been suggested for the identification of a high yielding ideotype (THURLING 1991). Theoretically, apetalous plants are more effective in photosynthesis and in reallocation of photosynthesized assimilates due to the removal of the yellow flower layer, which reflects photosynthetically active radiation during flowering (CHAPMAN et al. 1984, MENDHAM et al. 1991, FRAY et al. 1997). In addition, apetalous plants may be less susceptible against rapeseed stem rot (Sclerotinia sclerotiorum) (MC LEAN 1958, KRÜGER 1974, LARMARQUE 1983) and rapeseed downy mildew (Peronospora parasitica) (LÜ \& Fu 1990), because petals are assumed to be the infection sites.

The objective of the present study was to compare an apetalous mutant with partial apetalous and normal genotypes for weight of floral organs, absorption of photosynthetically active radiation (PAR) through the crop canopy, leaf area index ( $\mathrm{LAl})$, weight of total biomass, harvest index $(\mathrm{HI})$, yield, oil and 
protein content. The influence of petals was investigated in field experiments under different plant densities and three levels of nitrogen supply.

\section{Materials and methods}

The source of the apetalous flowers is a mutant from a mutagenesis program (TENGBE 1990). The origin of this mutant and its inheritance will be published in more detail separately (JIANG \& BECKER, in preparation). This mutant was crossed with the German winter oilseed rape cultivar 'Falcon'. The tested genotypes with apetalous (AP) and half apetalous (HAP) flowers were sister lines in F6 generation. The tested genotype with normal petalled flowers (NP) was a line in F4 generation from a backcross of F3 ('ap-Tengbe' x 'Falcon') with 'Falcon'. The three materials tested were morphologically similar except for petals.

The three genotypes (AP, HAP, NP) and 'Falcon' as check were tested in a field experiment as a split-split-plot design with three replications and with nitrogen application $(\mathrm{N})$ as main plots, plant density (D) as subplots and genotypes $(G)$ as sub-subplots. The nitrogen levels N0, N100 and N200 were without fertilization and with application of 100 or $200 \mathrm{~kg} \mathrm{~N} / \mathrm{ha}$, respectively. The plant densities D30, D80 and D120 were 30, 80 and 120 plants $/ \mathrm{m}^{2}$. The experiment was conducted in 1998 at the two locations Reinshof (near Göttingen) and Teendorf (near Uelzen, Lüneburger Heide). Plot size was $12 \mathrm{~m}^{2}$ at Reinshof and $15 \mathrm{~m}^{2}$ at Teendorf.

At both locations, grain yield, oil and protein content were determined. At Reinshof, additional parameters were measured during the vegetation period: the weight of the floral organs was measured in two replications of the combination N100D80. From each plot 100 newly opened flowers from the main shoot were collected and dissected into pedicel, calyx, petal, stamen and pistil. The different fractions were weighed after drying at $60{ }^{\circ} \mathrm{C}$ for 24 hours. The photosynthetically active radiation (PAR) was determined by tube solarimeters (0.97 $\mathrm{m}$ in length, Delta-T Devices Ltd., Cambridge, England) at initial flowering on ground surface on April 23, 1998 and at peak flowering on ground surface on May 11, 1998, and at base of flower layer on May 14, 1998. The measurement at base of flower layer was only made in the plots with 
nitrogen and density combinations of N0D30, N100D80 and N200D120. Tube solarimeters were inserted in the middle of a plot perpendicular to the direction of sowing; one tube was laid as reference on the soil surface outside the plots with the same angle to solar radiation. The tube solarimeters measure solar radiation at wavelengths between 400 and $2200 \mathrm{~nm}$. According to MONTEITH (1993), the light transmission in wavelength of PAR $\left(\tau_{P A R}\right)$ was converted by the following equation:

$\tau_{\text {PAR }}=\tau_{\text {TOTAL }}{ }^{1.325}$

with

$\tau_{P A R}$ : the light transmission in wavelength of PAR $(400-700 \mathrm{~nm})$

$\tau_{\text {TOTAL: }}$ the light transmission in wavelength of $400-2200 \mathrm{~nm}$

The leaf area index ( $\mathrm{LAl}$ ) was measured at three dates. The first date was 2-3 weeks before anthesis on April 7, 1998, to compare the genotypes before petals could have had any influence. The second date was at peak flowering on May 4, 1998, and the last date was 2-3 weeks after flowering on June 9, 1998. LAl was calculated by the following equations:

$\mathrm{LAl}=\mathrm{LA} \mathrm{Aplot}_{\text {/Areaplot }}$

$\mathrm{LA}_{\text {Plot }}=\mathrm{DM} \mathrm{M}_{\text {Plot }} / \mathrm{LA}$ KgDM

with

LA $A_{\text {Plot: }}$ Total leaf area per plot

Areaplot: Area of a plot

DMPlot: Dry matter of leaves per plot $(\mathrm{kg})$

$L A_{K g D M}$ : Area of one $\mathrm{kg}$ dry matter of leaves, which was estimated for each plot from the weight of 100 pieces of dried leaves cut with a card of $16 \mathrm{~cm}^{2}$ in size.

Weight of total biomass was determined three weeks after flowering. Harvest index $(\mathrm{HI})$ was determined by weighing dry grain and total biomass.

As samples twelve plants/plot were harvested and dried at $106^{\circ} \mathrm{C}$ for about 36 hours each date for LAI or weight of total biomass.

Oil and protein contents were measured by Near Infrared Reflectance Spectroscopy (NIRS).

Analysis of variance was performed using the software PLABSTAT (UTZ 1994). Statistical significance was tested by appropriate F-Test. The least significant difference (LSD) for $\mathrm{P}=0.05$ are included in the tables and figures. 


\section{Results}

\section{Differences in flower morphology}

The normal genotype (NP) had the largest weight of whole flower, which was $6.8 \%$ and $20.18 \%$ heavier than that of AP and HAP respectively (Table 7.3-1). The three genotypes differed significantly for all other parts of the flower, too. For all parts of the flower except petals, the AP genotype had the heaviest floral organs.

The correlation coefficients among floral organs reveal that the weight of petals is significantly and negatively correlated with the weight of pistil, pedicel and calyx (Table 7.3-2). This indicates, that the elimination of petals promotes the development of the other floral organs.

Table 7.3-1: Weight of floral organs (mg) of the apetalous (AP), half apetalous (HAP) and normal petalled (NP) lines at Reinshof 1998.

Gewicht verschiedener Blütenteile $(\mathrm{mg})$ von blütenblattlosen $(A P)$, halb-blütenblattlosen (HAP) and normalen (NP) Genotypen, Reinshof 1998.

\begin{tabular}{lllllll} 
Genotype & Whole flower & Petal & Pedicel & Calyx & Stamen & Pistil \\
\hline AP & 17.36 & 0.00 & 4.30 & 3.67 & 5.47 & 3.91 \\
HAP & 15.43 & 3.06 & 3.08 & 2.65 & 4.37 & 2.27 \\
NP & 18.55 & 6.79 & 2.93 & 2.42 & 4.70 & 1.71 \\
LSD $_{0.05}$ & 0.79 & 0.89 & 0.10 & 0.16 & 0.74 & 0.24 \\
\hline
\end{tabular}

Table 7.3-2: Correlation coefficients among floral organs, Reinshof 1998

Korrelationskoeffizienten für die Beziehung der Blütenteile untereinander, Reinshof 1998

\begin{tabular}{|c|c|c|c|c|c|}
\hline & Petal & Pedicel & Calyx & Stamen & Pistil \\
\hline Whole flower & 0.43 & 0.04 & -0.04 & 0.40 & -0.11 \\
\hline Petal & & $-0.88^{*}$ & $-0.91^{*}$ & -0.63 & $-0.94^{* *}$ \\
\hline Pedicle & & & $0.98^{* *}$ & $0.90^{*}$ & $0.99^{* *}$ \\
\hline Calyx & & & & $0.83^{*}$ & $0.99^{* *}$ \\
\hline Stamen & & & & & $0.82^{*}$ \\
\hline
\end{tabular}

**, *: Significant at $1 \%$ and $5 \%$ level, respectively

\section{Effect of petals on PAR absorption}

At beginning of flowering, approximately $40 \%$ of the incoming PAR was 
absorbed by the crop canopy (Figure 7.3-1). The PAR absorption increased to about $51 \%$ at peak flowering. Analysis of variance (data not presented) shows that the effect of genotype on total PAR absorption was not statistically significant.

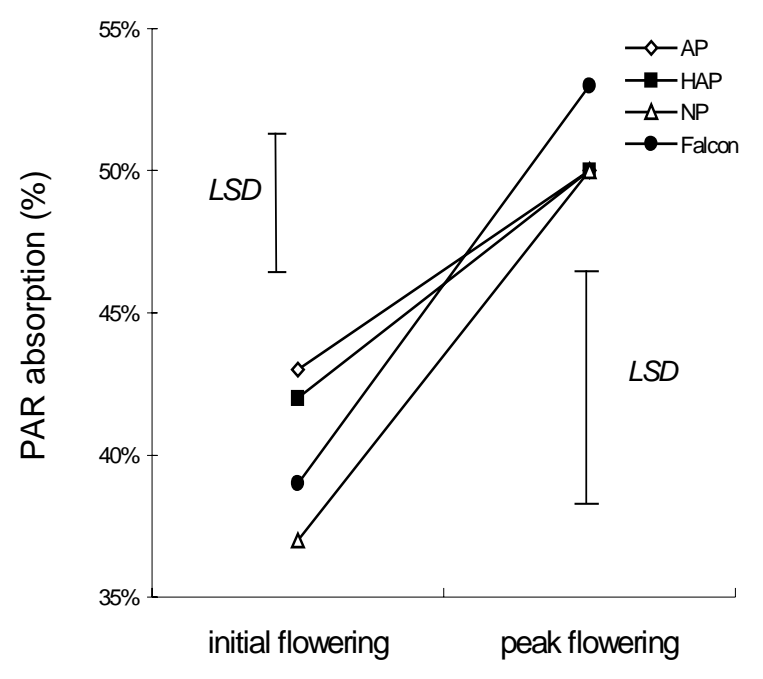

Flowering stage

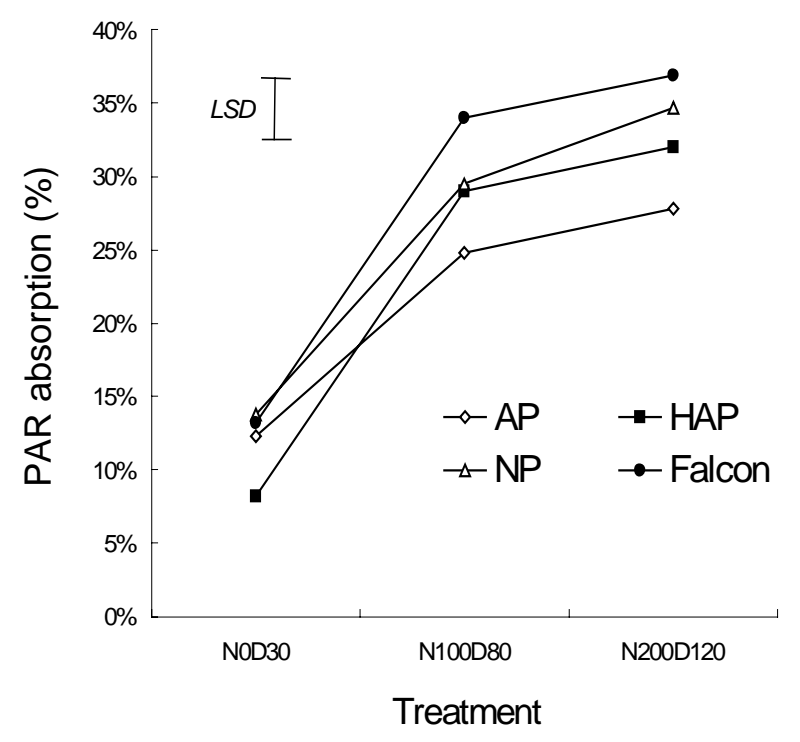

Figure 7.3-1: Photosynthetically active radiation (PAR) absorption at initial and peak flowering, measured on ground surface, Reinshof 1998, with least significant difference (LSD) for $\mathrm{P}=0.05$. AP: apetalous line; HAP: half apetalous line; NP: normal petalled line.

PAR Absorption bei Blühbeginn und bei bei Vollblüte, gemessen an der Bodenoberfläche, Reinshof 1998, mit Grenzdifferenz (LSD) für $P=0.05$. $A P$ : blütenblattlose Linie; HAP: halb-blütenblattlose Linie; NP: normale Linie.

Figure 7.3-2: Photosynthetically active radiation (PAR) absorption at peak flowering measured at base of flower layer in low (N0D30), normal (N100D80) and high (N200D120) nitrogen and plant density levels, Reinshof 1998. AP: apetalous line; HAP: half apetalous line; NP: normal petalled line.

PAR Absorption bei Vollblüte, gemessen unterhalb der Blüten bei niedriger (NOD30), normaler (N100D80) and hoher (N200D120) Stickstoffversorgung und Pflanzendichte, Reinshof 1998. AP: blütenblattlose Linie; HAP: halb-blütenblattlose Linie; NP: normale Linie.

Measuring PAR absorption at the base of the flower layer at peak flowering revealed an obvious effect of the petals, depending in its magnitude on the agronomic treatment (Figure 7.3-2). With the treatment of NOD30, the petal's effect on PAR absorption was not significant, whereas with the treatments of N100D80 and N200D120, the PAR absorption of AP was significantly smaller 
than that of NP, yet there was no significant difference between AP and HAP, HAP and NP.

Thus the petals are limiting light transmission to the leaves directly below the flower layer, especially with higher $\mathrm{N}$ application and at high plant density.

\section{Effect of petals on LAI}

The results of the LAI measurements are illustrated in Figures 7.3a-7.3c. Before anthesis (Figure 7.3-3a), the check cultivar 'Falcon' had the greatest LAI with 3.04 as mean, followed by AP, HAP and NP with mean LAI of 2.43, 2.34 and 1.75 , respectively. AP and HAP had no significant difference for $L A l$, and their LAls were significantly greater than that of NP, and significantly smaller than that of 'Falcon'. At this stage, the effect of nitrogen on LAl was not significant, whereas the effect of density was significant at $1 \%$ level and the mean LAls were $1.73,2.64$ and 2.79 for D30, D80 and D120, respectively. At peak flowering (Figure 7.3-3b), there was a significant interaction between genotype and nitrogen level. The effect of genotype was not significant when N0 or N100 was applied. However, with N200, AP had a mean LAI of 9.32, significantly greater than the LAl of HAP (3.12) and NP (4.91) and even greater than the LAI of 'Falcon' (8.53), although this difference was not significant. The effect of nitrogen was also significant. Increasing the amount of added nitrogen results in an increase in LAI regardless of the shading effect. The effect of population density depended merely on nitrogen level. Two weeks after end of flowering (Figure 7.3-3c), the interaction among genotype, nitrogen level and population density became significant at $1 \%$ level. Petal's shading effect existed depending on nitrogen level and population density. Without nitrogen application (N0) or with N100, The mean LAls of the four genotypes were very small and can be neglected regardless of density. However, at very high nitrogen application (N200), AP responded to higher densities with significantly higher LAls and had the maximun LAI at D120, whereas HAP and NP had their maximum LAls at D80. The LAl of HAP significantly decreased when population density increased up to D120, whereas the LAl of NP did not significantly changes. 'Falcon' had its maximum LAI at D30. It had the least LAI at D80. 

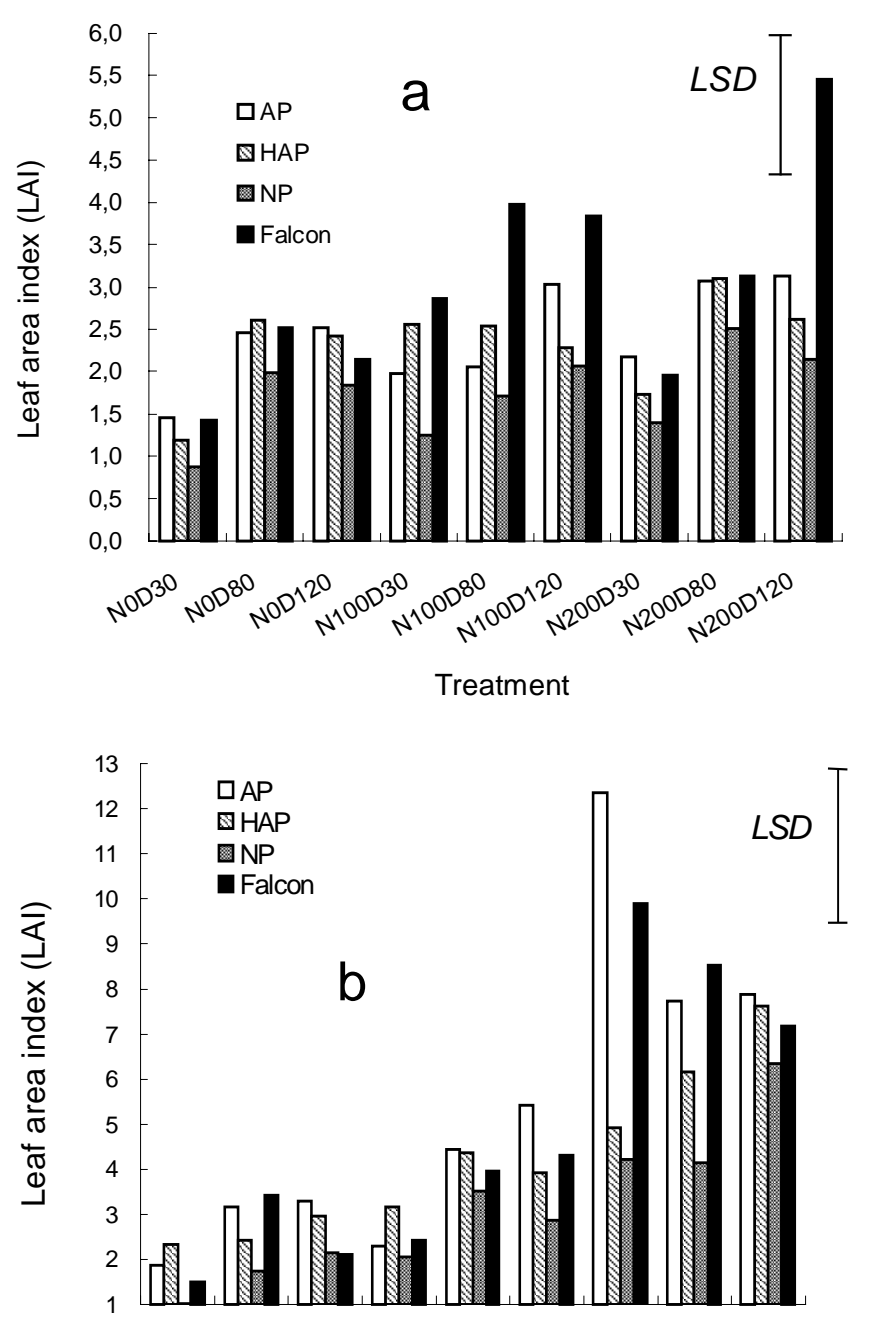

Fig. 3: Mean leaf area index (LAl) at various combinations of genotype $(G)$, nitrogen level $(N)$ and plant density (D) before anthesis (a), at peak flowering (b) and after flowering (c), Reinshof 1998. AP: apetalous line; HAP: half apetalous line; NP: normal petalled line.

Durchschnittlicher

Blattflächenindex (LAI) bei unterschiedlichen Kombinationen von Genotyp (G), Stickstoffversorgung ( $N$ ) und Pflanzendichte $(D)$ vor Blüte (a), bei Vollblüte (b) und nach Blühende (c), Reinshof 1998. AP: blütenblattlose Linie; HAP: halb-blütenblattlose Linie; NP: normale Linie.

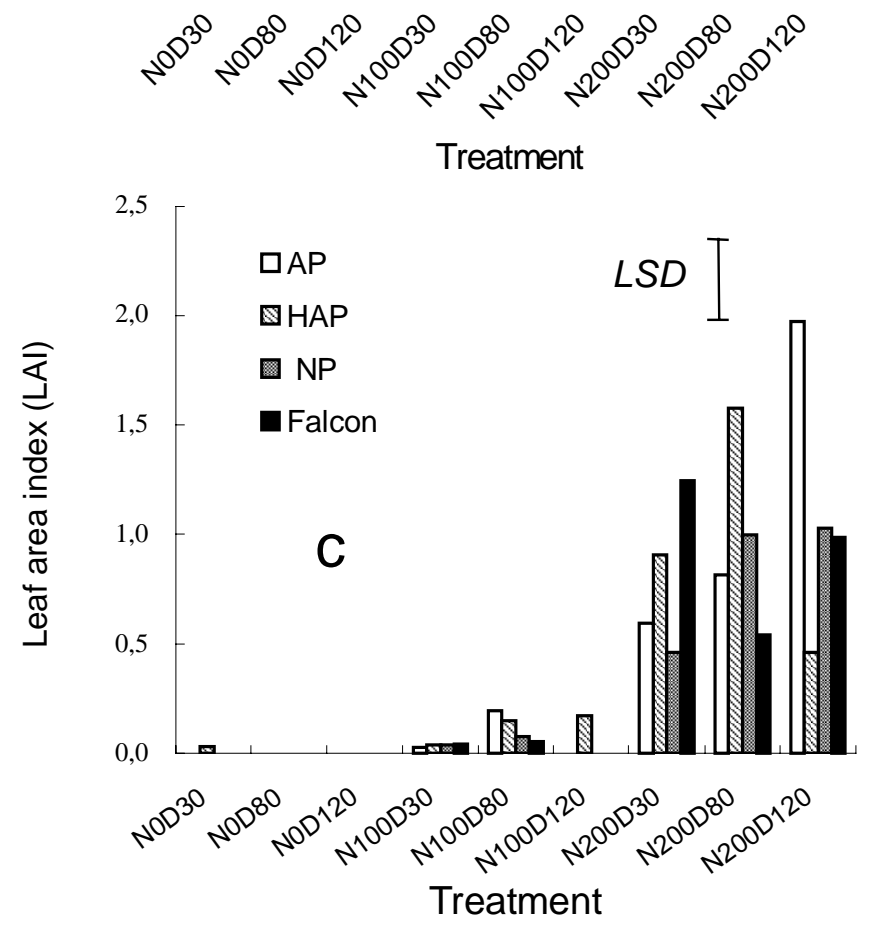


Figure 7.3-4 illustrates the development of mean LAI of the various genotypes. There was no significant difference between AP and HAP for LAI before anthesis. However, at peak flowering, the LAI of AP was about $28 \%$ higher than that of HAP, while the difference between HAP and NP was enlarged too. 'Falcon' had the highest LAI before anthesis, but AP surpassed 'Falcon' significantly at peak flowering by about $11.6 \%$. Three weeks after the end of flowering, AP and HAP had about $37.9 \%$ and $27.6 \%$ more remaining active green leaves than NP in average.

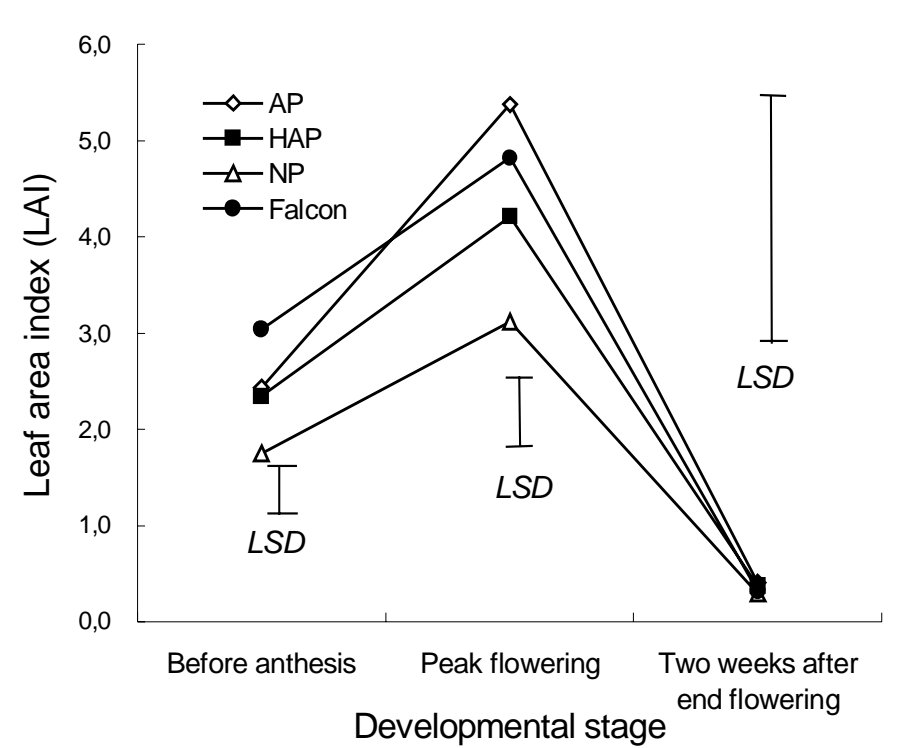

Figure 7.3-4: Mean leaf area index (LAI) at different developmental stages, Reinshof 1998. AP: apetalous line; HAP: half apetalous line; NP: normal petalled line.

Durchschnittliche

Blattflächenindex in unterschiedlichen Entwicklunsphasen, Reinshof 1998. AP: blütenblattlose Linie; HAP: halb-blütenblattlose Linie; $N P$ : normale Linie

\section{Effect of petals on weight of total biomass and $\mathrm{HI}$}

The results for the weight of total biomass are shown in Figure 7.3-5. AP had a higher biomass than HAP, while HAP had a higher biomass than NP in most circumstances, in particular with very high nitrogen application plus very high population density (N200D120), where AP had approximately $35 \%$ more biomass than HAP, and HAP had $26 \%$ more biomass than NP. Generally, biomass responded slightly positive to increasing nitrogen application. The response of weight of total biomass to increasing population density was not uniform; it largely depended on nitrogen level and genotype.

The differences in $\mathrm{HI}$ were generally opposite to those in weight of total biomass (Figure 7.3-6). AP had smaller HI than HAP and HAP had smaller HI than NP in most cases. The differences were largest at the lowest population 
density (D30). Generally HI responded negatively to increasing population density.

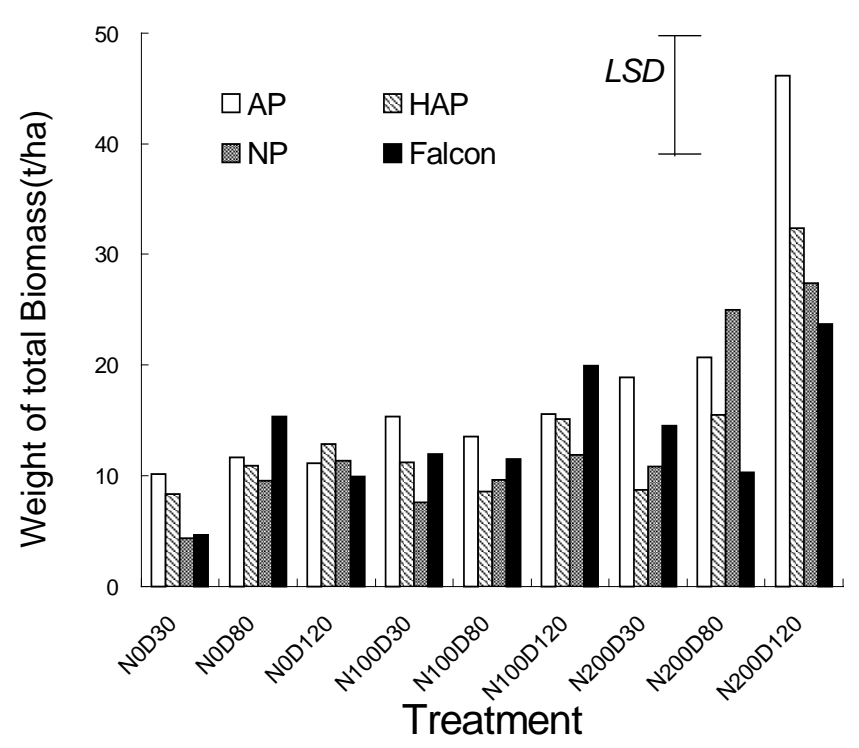

Figure 7.3-5: Mean weight of total biomass at various combinations of genotype $(\mathrm{G})$, nitrogen level $(\mathrm{N})$ and plant density (D), Reinshof 1998. AP: apetalous line; HAP: half apetalous line; NP: normal petalled line.

Durchschnittliche Biomasse für unterschiedliche Kombinationen von Genotyp (G), Stickstoffversorgung (N) und Pflanzendichte (D), Reinshof 1998. AP: blütenblattlose Linie; HAP: halb-blütenblattlose Linie; NP: normale Linie.

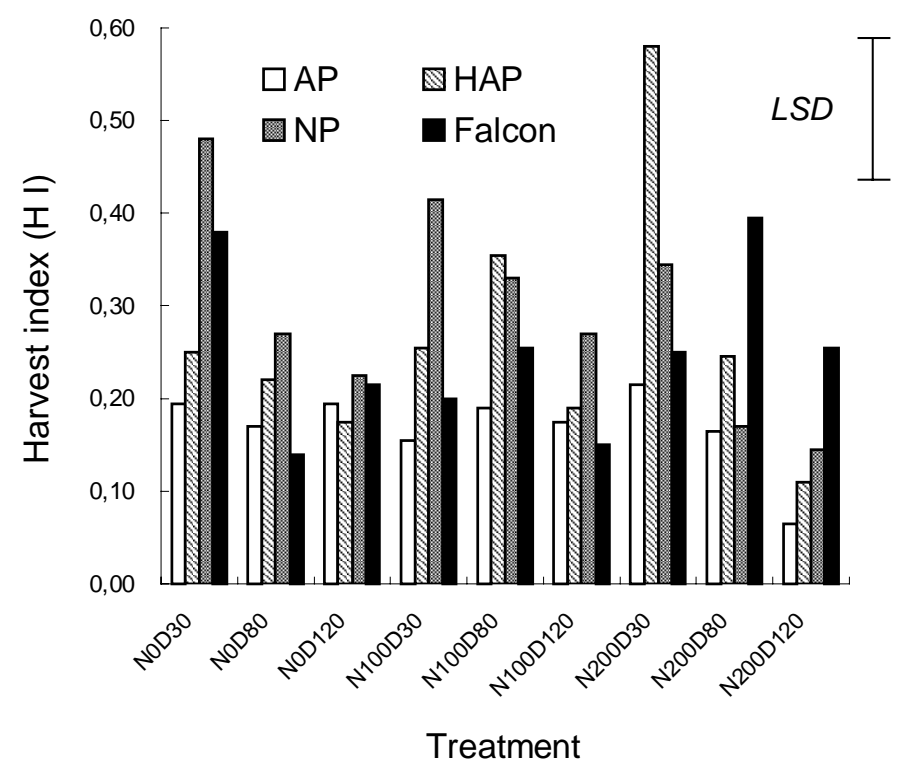

Figure 7.3-6: Mean harvest index $(\mathrm{HI})$ at various combinations of genotype $(\mathrm{G})$, nitrogen level $(\mathrm{N})$ and plant density (D), Reinshof 1998. AP: apetalous line; HAP: half apetalous line; NP: normal petalled line.

Durchschnittliche Ernteindex (HI) bei unterschiedlichen Kombinationen von Genotyp (G), Stickstoffversorgung $(N)$ und Pflanzendichte (D), Reinshof 1998. AP: blütenblattlose Linie; HAP: halb-blütenblattlose Linie; NP: normale Linie

\section{Effect of petals on yield}

The AP and HAP genotypes had lower yield than NP and 'Falcon' at any combination of nitrogen and population density (Figure 7.3-7). Increasing the amount of nitrogen resulted in an increase in yield for all genotypes, in average, the highest yield was obtained at D80, but the effect of population density on yield was also depending on genotype and nitrogen supply. 
The mean yield of each genotype at two locations is listed in Table 7.3-3. Mean yield of AP was lower than that of HAP. Mean yield of AP and HAP was significantly lower than that of the NP and 'Falcon'. There was no significant difference between AP and HAP, or between NP and 'Falcon' for yield.



Figure 7.3-7: Mean grain yield at various combinations of genotype $(\mathrm{G})$, nitrogen level $(\mathrm{N})$ and plant density (D), Reinshof and Teendorf, 1998.

Durchschnittliche Samenertrag bei unterschiedlichen Kombinationen von Genotyp (G), Stickstoffversorgung $(N)$ und Pflanzendichte $(D)$ von Reinshof und Teendorf, 1998.

Table7.3-3: Mean seed yield (t/ha) of the apetalous (AP), half apetalous (HAP) and normal petalled (NP) lines, Reinshof and Teendorf 1998.

Durchschnittliche Samensrtrag (t/ha) von blütenblattlosen $(A P)$, halb-blütenblattlosen (HAP) and normalen (NP) Genotypen, Reinshof und Teendorf 1998.

\begin{tabular}{llll}
\hline & Reinshof & Teendorf & Mean \\
\hline AP & 2.41 & 2.47 & 2.45 \\
HAP & 2.61 & 2.53 & 2.58 \\
NP & 2.72 & 3.06 & 2.89 \\
'Falcon' & 2.64 & 3.00 & 2.81 \\
LSD (0.05) & 0.15 & 0.49 & 0.35 \\
\hline
\end{tabular}

The effect of genotype on oil and protein content was not significant (data not shown). In general, oil content responded negatively to increasing nitrogen supply, and the effect of population density depended largely on nitrogen level and genotype. Protein content responded positively to increasing nitrogen application regardless of genotype and population density. 


\section{Discussion}

In the literature different experimental results on PAR transmission are reported. According to MENDHAM et al. (1991), with a flower density of about 25,000 per $\mathrm{m}^{2}$ (population density and nitrogen level unknown) the flower layer absorbed $60 \%$ of incoming solar radiation (or $79 \%$ PAR) and apetalous allowed $30 \%$ more radiation to reach the base of the flower layer. Yet CHAPMAN et al. (1984) reported that with normal agronomic conditions, 76, 93 and $94 \%$ PAR absorption was detected at $50 \mathrm{~cm}$ from the ground surface at early flowering, late flowering and pod filling stages, respectively. Our result shows that even with N200D120, the flower layer of the European commercial variety 'Falcon' absorbed only about $37 \%$ of incoming PAR at peak flowering, while the apetalous allowed $32 \%$ more and the half apetalous let in 15\% more incoming radiation relatively in comparison to 'Falcon' (Figure 7.3-2). In addition, MENDHAM's result indicated that apetalous consistently transmitted a greater percentage of the incoming radiation at all heights. In our investigations, however, by measurement on the soil surface, there was little difference between AP and NP, indicating petals may have little effect influencing the PAR transmission on leaves of lower height. The results of PAR adsorption of a flower layer may be mainly influenced by the position of a plant that PAR was measured. It was very difficult to determine which is the correct position representing the bottom of a flower layer. Besides that, some other factors, i.e. agronomic treatment, plant structure, type of solarimeter, as well as light intensity of certain location etc. might have influence on the result of PAR measurement too.

Our results showed that larger LAI of AP and HAP related to more PAR transmission on the upper leaves. From another point of view, without or with fewer petals, the plants maintain more photosynthesized assimilates in leaves or other floral organs, as the petal is no photosynthesizing organ but only consuming photosynthesized assimilates. According to MENDHAM et al. (1981), around 25000 flowers per $\mathrm{m}^{2}$ were produced by typical European cultivar of winter oilseed rape, that equivalents approximately $125-200 \mathrm{~g}$ dry matter per $\mathrm{m}^{2}$, if we assume that petals of a normal flower weigh 6-8 $\mathrm{mg}$. 
The most striking result is that although AP had less PAR absorption at higher levels of nitrogen and population density (Figure 7.3-2) and greater LAI (Figure 7.3-3), it yielded less than NP and 'Falcon' in most combination of $\mathrm{N}$ and D (Fig 7). The result did not agree with MENDHAM et al. (1991), who reported up to $48 \%$ higher yield of apetalous lines in comparison to the Australian commercial variety 'Marnoo'.

To explain this, it should be realized that yield is a typical quantitative character, determined by the strong interaction between genetic and environmental factors. Besides the removal of shading effect, which is mostly discussed and regarded as an advantage, the apetalous genotype may have other advantages to yield. One might be the effect of lessening transpiration, which might permit greater drought tolerance. Rapeseed yield is reportedly most susceptible to drought especially at flowering stage (THURLING 1991). In the experiment by MENDHAM et al. (1991), the largest yield increase of apetalous genotypes was observed under drought stress without irrigation. The apetalous benefited not only from less transpiration, but also from higher root activity, which was promoted by longer active leaf life, while normal petalled crops generally showed little increase in root weight after flowering started. Apetalous types maintained a consistently higher stomatal conductance than 'Marnoo', but also a higher leaf turgor at lower osmotic potentials. All these led to better yield performance in a drought environment. In our experiment, this potential advantage of apetalous flowers did not result in higher yield, because no drought stress occurred during flowering.

On the other hand, the direct advantage of larger and longer green leaves to yield is controversial. The role of leaves during and after flowering has been frequently reported. FREYMAN et al. (1973), KROGMAN \& HOBBS (1975) and MAJOR (1977) suggested that rapeseed leaves make an important contribution to yield. However, CHAPMAN et al. (1984) observed that during rapid pod filling the pods themselves are the most important source of assimilates and that also photosynthesis of the stem is of importance. BRAR \& THIES (1977) estimated that approximately $37 \%$ of seed dry matter was contributed by the leaves, which is in agreement with defoliation experiments using Brassica rapa (FREYMAN et al. 1973). Thus at early stage of pod development, the leaves 
probably supply a small amount of carbon for reproductive development but their role in the development of stem material which is subsequently remobilized to provide carbon for pods may be more important. Our results support the view that leaf area at peak flowering or later may not be limiting yield.

The lower yield performance of AP may due also to the shorter duration of flowering which was 2-3 days shorter than that of NP and 3-5 days shorter than that of 'Falcon'. The positive influence of longer flowering duration on yield was suggested by AsthAN \& PANDEY (1977) and OLIVIERI \& PARRINI (1979). Moreover, the apetaleous mutant we used, 'ap-Tengbe', shows a lower pollen production and pollen vitality than normal forms (data not shown).

In conclusion, our data do not support the hypothesis, that apetalous oilseed rape responds to the higher light absorption during flowering with an increased grain yield. A further potential advantage of apetalous types, a better disease resistance, will be investigated in further studies.

\section{Acknowledgements}

We thank Dr. K. Schmidtke and Dr. H. Kimpel-Freund for support when using the Delta-T Logger for measuring solar radiation and Dr. Jürgen Koch, Semundo, for providing the possibility for field trials in Teendorf. The first author was financially supported by the German Academic Exchange Service (DAAD).

\section{References}

Asthana, A. N., \& U. K. PANDEY, 1977: Combining ability and rank correlation in diallel cross of Indian Mustard B. juncea. Exp. Agric. 13, 71-79.

BECKER H.C., H. LÖPTIEN, \& G. RÖBblen, 1999: Breeding: an overview. In: C. GÓMEZ-CAMPO (ed). Biology of Brassica Coenospecies. Elsevier, Amsterdam.

BRAR, G. \& W. THIES, 1977: Contribution of leaves, stem, siliques and seed to dry matter accumulation in ripening seeds of rapeseed Brassica napus $\mathrm{L}$. 
Zeitschrift für Pflanzenphysiologie 82, 1-13.

Chapman, J. F., R. W. Daniels \& D. H. Scarisbrick, 1984: Field studies on ${ }^{14} \mathrm{C}$ assimilate fixation and movement in oil-seed rape (B. napus). J. Agricult. Sci., Cambridge 102, 23-31.

Fray, M. J., P. Puangsomlee, J. Goodrich, G. Coupland, E. J. Evans, A. E. ARTHUR \& D. J. LYDIATE, 1997: The genetics of stamenoil petal production in oilseed rape (Brassica napus) and equivalent variation in Arabidopsis thaliana. Theor. Appl. Genet. 94, 731-736.

Freyman, S., W. A. ChARNetSkI \& R. K. CROOKSton, 1973: Role of leaves in the formation of seed. Can. J. Plant Sci. 53, 693-694.

Krogman, K. K. \& E. H. HoBBS, 1975: Yield and morphological response of rape (Brassica campestris L. cv. Span) to irrigation and fertilizer treatments. Can. J. Plant Sci. 55, 903-909

KRÜGER, W., 1975: Die Beeinflussung der Apothezien- und AscosporenEntwicklung des Rapskrebserregers Sclerotinia sclerotiorum (Lib.) de Bary durch Umweltfaktoren. Pfl. Krankh. 2, 101-108.

LARMARQUE, C., 1983: Conditions climatiques qui favorisent le processus naturel de la contamination du colza par le Sclerotinia sclerotiorum. Proc. GCIRC $6^{\text {th }}$ International Rapeseed Congress, Paris, France, 957-962.

LÜ, Z.J. \& S.Z. FU, 1990: Inheritance of apetalous character in rape (Brassica napus $L$.) and ist implications in breeding. Jiangshu J. Agric. Sci. 6, 30-36.

MAJOR, D. J., 1977: Analysis of growth of irrigated rape. Can. J. Plant Sci. 53, 193-197.

MC LEAN, D. M., 1958: Role of dead flower parts in infection of certain crucifers 
by Sclerotinia sclerotiorum (Lib.) De. Bary. Plant Disease Rep. 42, 663-666.

Mendham, N. J., P. A. Shipway \& R. K. SCOTt, 1981: The convergent evolution of annual seed crops in agriculture. Adv. Agron. 36, 97-143.

Mendham, N. J., M. S. S. RaO \& G. C. BuzzA, 1991: The apetaous flower character as component of a high yielding ideotype. Proc. GCIRC $8^{\text {th }}$ International Rapeseed Congress, Saskatoon, Canada, 596-600.

MONTEITH, J. L., 1993: Using tube solarimeters to measure radiation intercepted by crop canopies and to analyze stand growth. Application Note Delta-T Devices Ltd., Burwell. Cambridge, England.

OlIVIERI, A. M. \& P. PARRINI, 1979: Earliness of flowering in winter and summer rapeseed. Cruciferae Newsletter 4, 22-23.

UTZ, H. F., 1994: PLABSTAT (Version 2H (L)), ein Computerprogramm für statistische Analysen von Pflanzenzüchtungsexperimenten. Universität Hohenheim, Stuttgart.

RöBbeLEN, G., 1997: The evolution of rapeseed quality. GCIRC Bulletin 14, 102-113.

TengBe, M. A., 1990: Züchterische Nutzung von induzierten Mutanten bei Raps (Brassica napus L.) - Veränderte Polyenfettsäure-Zusammensetzung und Blütenblattlosigkeit. Diss. Georg-August-Universität Göttingen, Cuvillier Verlag Göttingen, Göttingen.

THURLING, N., 1991: Application of the ideotype concept in breeding for higher yield in the oilseed Brassicas. Field Crops Res. 26, 201-219. 


\title{
7.4 Influence of apetalous flowers on infection of Sclerotinia sclerotiorum in oilseed rape (Brassica napus)
}

L. Jiang ${ }^{1}$, H. C. Becker ${ }^{1}$, Q. Zhao ${ }^{2}$, G. Wolf ${ }^{2}$

${ }^{1}$ Institute of Agronomy and Plant Breeding, Georg-August-University Göttingen, Von Siebold Straße 8, 37075 Göttingen, Germany;

${ }^{2}$ Institute of Plant Pathology and Plant Protection, Georg-August-University Göttingen, Grisebach Staße 6, 37077 Göttingen, Germany

With 1 table and 7 figures

\begin{abstract}
Apetalous genotypes of oilseed rape may be less infected from some diseases, in particular Sclerotinia sclerotiorum, which are distributed by petals when they wilt and drop on leaves tissue. In our study, (1) three apetalous lines, one partial apetalous line, two normal petalled lines and a Chinese cultivar were grown and compared for infected rate (IR) and severity index of the infected plants (SI) by field scoring in China; (2) Different enzyme tests were compared for the efficiency in quantification of Sclerotinia infection. The suitable methods were applied to investigate the infection degree (ID) of three pairs of sister lines with apetalous or with normal flowers and two German cultivars grown at two locations in northern Germany. The result shows (1) that by field scoring in China one of the apetalous lines was significantly lower in IR rate than other tested lines and there was no significant difference among the genotypes for SI; (2) Protease and xylanase tests were appropriate to distinguish ID of Sclerotinia disease. An apetalous line was found with the least ID. Three apetalous lines had less ID than their respective normal petalled lines. (3) In the field experiments at two locations in northern Germany, yield advantage was demonstrated by apetalous genotypes in two pairs of sister lines.
\end{abstract}

Key words: Brassica napus, apetalous flowers, Sclerotinia disease, enzyme test, protease, xylanase 


\section{Introduction}

Sclerotinia disease (Sclerotinia sclerotiorum) is reported in most of the areas important for rapeseed production (Paul 1991, Fang \& Platford 1994, Thomson et al. 1995). The disease results in decreased seed weight and hence yield loss. In extreme case, dead plants can be found in fields when natural infestation is heavy.

The infection can be identified by the symptom of white colored canker on stem during or after flowering, or by black sclerotia grains inside the stalks. It is caused by ascospores, which develop in apothecia and are discharged in spring or early summer. Discharging of the ascospores is influenced by weather. During dry and slightly windy conditions many spores are ejected (Krüger 1975, Heitefuss et al. 1987). The spores may adhere on young flower petals. They germinate, penetrate the host with short germ tubes that lead to collapse of the epidermal cells of petals (Jamaux et al. 1994). Petals play an important role in infecting the plants further. First, they favored the infection by serving as C-source that is needed by the invading fungus (Krüger 1975); second, petals that covered with mycelium are the infection sites, where the mycelium invades leaf tissues. The ascospores that land directly on leaf surface do not germinate (Mc Lean 1958, Larmaque 1983, Jamaux 1994, 1999).

Once plant gets infected by a pathogen, a range of enzymes degrading plant cell wall are excreted in epidermal cells with extra amount. The amounts of these hydrolysates may correlate to infected degree of a certain disease (Bateman et al. 1973, Cooper \& Wood 1980, Perez \& Tena 1990). Quantitative techniques have been developed to analyze infected degree from a range of diseases (Wirth \& Wolf 1990, Afshari-Azad 1992).

Genotypes that are immune or highly resistant to Sclerotinia disease were hardly found in the existing germplasm of oilseed rape (Newmann 1987, Singh \& Tripathi 1994, Zhou 1994, Jiang et al. 1995). Husbandry measures, such as rotation, removal of stubble from the previous crop, stimulation of soil microorganisms and prevention of plant injury, may be helpful to reduce the disease (Kharbanda \& Tewari 1996, Twengstrom et al. 1998, Wahmhoff et al. 1999), but are laborious. Genotypes with apetalous flowers may be an 
alternative to be applied in areas where the natural infestation is heavy.

Not much information about apetalous genotypes concerning their ability in avoiding Sclerotinia disease is available in literature. The objective of our investigation is to compare some apetalous and normal petalled lines for Sclerotinia infection, and to compare the efficiency of enzyme tests in quantitatively identifying infection degree from Sclerotinia disease.

\section{Materials and Methods}

(1) Field scoring of infected rate (IR), severity index of infected plants (SI) for the field experiment at Hangzhou

Tested were the following plant materials:

AP1: F6 ('ap-Tengbe' $\times$ 'Falcon') plants with apetalous flowers HAP: F6 ('ap-Tengbe' $\times$ 'Falcon') plants with partial apetalous flowers NP: F4 (F3 ('ap-Tengbe' $\times$ 'Falcon') $\times$ 'Falcon') plants with normal flowers AP2: F6 ('ap-Renard' $\times$ 'ap-Tengbe') plants with apetalous flowers AP3: F6 (('camp.' $\times$ 'Libraska') $\times$ 'Lirajet') plants with apetalous flowers AP4: F4 (F2 ('ap-Renard' $\times$ 'ap-Tengbe') $\times$ 'Bristol') with apetalous flowers 'ZY-758': Local cultivar with normal flowers as control

Among the above lines, AP1, HAP and NP1 are sister lines. They have similar agronomic traits except for petals. 'ZY-758' is a Chinese cultivar served as control in comparison with the rest European plant materials.

Randomized complete blocks were designed with three repetitions. The plants were hand sowed in four rows with $33.3 \mathrm{~cm}$ in distance in a plot of 16.6 $\mathrm{m}^{2}$ in size at the experimental farm of Zhejiang Academy of Agricultural Sciences at Hangzhou, China. Natural infestation of sclerotinia disease was high in the selected field, where oilseed rape had been grown without rotation or fallow since many years. IR and SI were determined by scoring on 100 plants in a plot about two weeks before harvesting. IR and SI were calculated according to the following equitation.

$\mathrm{IR}=($ The number of infected plants / Total number of the plants investigated $) \times 100 \%$ 


$$
S I=\frac{1 \times n 1+2 \times n 2+3 \times n 3+4 \times n 4}{4(n 1+n 2+n 3+n 4)} \times 100 \%
$$

with,

ni: The number of plants of ith-severe level ( $\mathbf{i}=1-4)$

The severe levels of the infection were determined according to the following criterion (Zhou 1994):

0-level : no symptom can be found on the whole plant

$1^{\text {st }}$-level: less than one third of the branches on a plant are affected or small canker appears on major stem

$2^{\text {nd }}$-level: $1 / 3-1 / 2$ of the branches on a plant are affected; or large canker appears on the major stem

$3^{\text {rd }}$-level: more than $2 / 3$ of the branches on a plant are affected; or large canker appears on lower part of major stem

$4^{\text {th }}$-level: Whole plants are infected with nearly $100 \%$ yield loss

(2) Enzyme tests for infection degree (ID) of the field experiment at north Germany

Defination of infection degree (ID)

ID represents the severity of the infection from Sclerotinia disease positively related with the activity of a certain enzyme, such as protease, xylanase, etc. Method of enzyme analysis:

To determine the activity of the soluble enzymes, namely cellulase, protease, 1,3-B-glucanase and xylanase, which were extracted from the plant tissues infected by Sclerotinia disease, the method of micro colored plate developed by Wirth \& Wolf (1990) was adopted. The dissoluble substrate-RBB (dyestuff Remazol Brilliant Blue: a kind of dyestuff) compounds were used. The compounds can be broken into small units catalyzed by respective enzymes. $\mathrm{HCl}$ was applied so that the un-decomposed substrate-dyestuff molecules deposited. The decomposed substance was measured by spectrophotometer at wavelength $592 \mathrm{~nm}$ for the value of opstical density (OD) indicating activity of the enzyme reaction. 


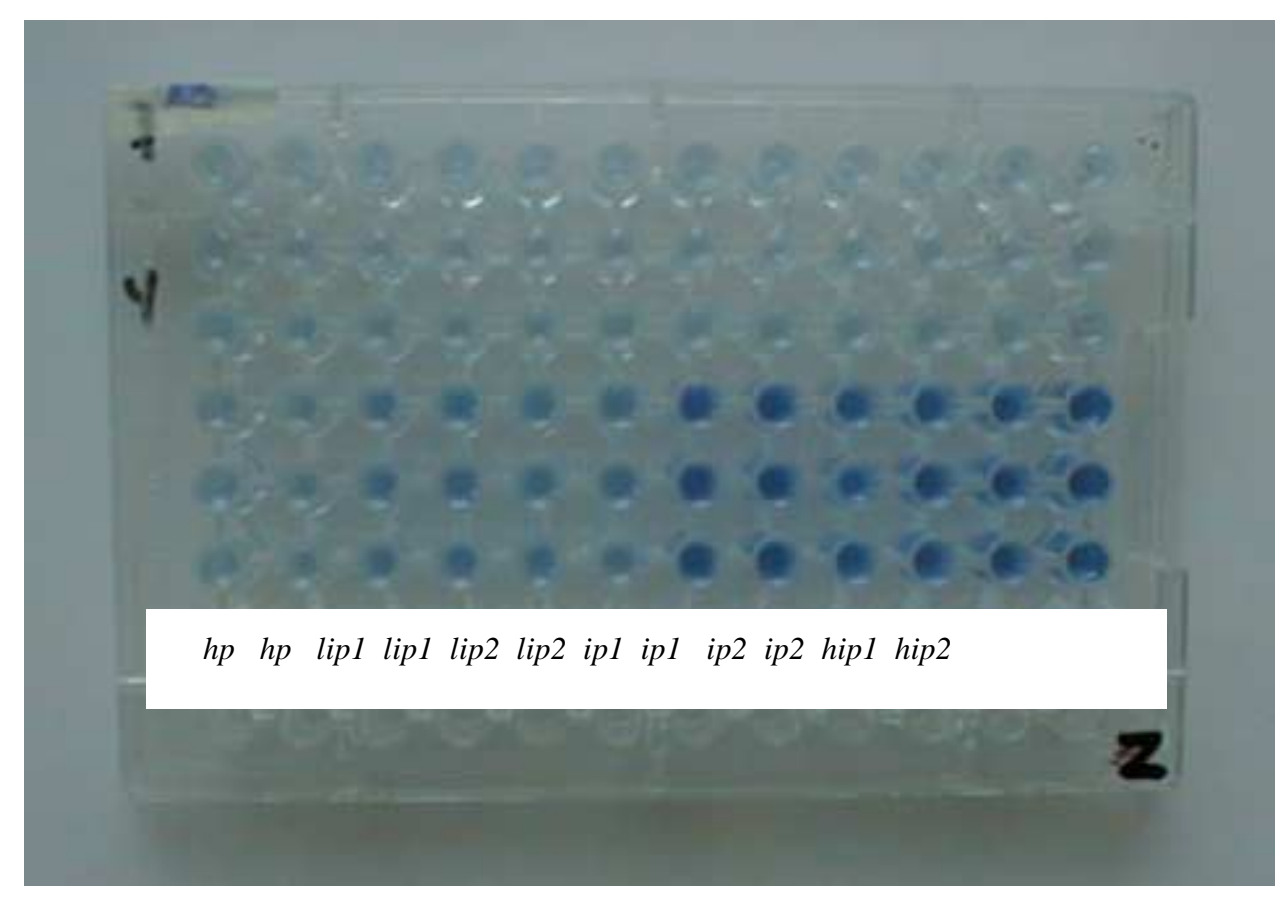

Figure 7.4-1 Micro coloured plate showing the activity of protease in plant tissue abstractions. hp: healthy plant, lip: less infected plant, ip: infected plant, hip heavily infected plant; the plant tissue samples were tested with lower concentration of abstractions $(1 \mathrm{~g} / 80 \mathrm{ml}$ left) and higher concentration of abstractions $(1 \mathrm{~g} / 60 \mathrm{ml}$ right))

The relationship between the enzyme's activity and the field observed infection from sclerotinia disease was investigated. One healthy plant ( $h p)$, two less infected plants (lip1 and lip2), two infected plants (ip1 and ip2) and one very heavily infected plant (hip) were determined by field observation at Reinshof, Göttingen. The plant samples were cut off, chopped, dried and milled. They were digested in buffer solution (0.1 M NaAc, PH 5.0) on gyratory shaker overnight. The activities of cellulase, protease, 1,3-ß-glucanase and xylanase were tested with the following concentrations of abstraction: (1) 1:20 (1 gram plant tissue in $20 \mathrm{ml}$ buffer solution ( $0.1 \mathrm{M} \mathrm{NaAc}, \mathrm{PH} 5.0$ with $\left.0.02 \% \mathrm{NaN}_{3}\right)$ ); (2) 1:40; (3) 1:60; and (4) 1:80.

To find out linear relationship between enzyme activity and ID, plant dry matter mixtures, which consisted of healthy and heavily infected plant tissues of various ratios in $1 \mathrm{gram}$, were tested. The concentrations of the extractions 
were $1: 105,1: 70$ and 1:35 for xylanase, protease and cellulase tests, respectively.

Enzyme tests for ID for the field experiments in northern Germany

Tested were three apetalous lines (AP5, AP6 and AP7), three normal petalled lines (NP2, NP3 and NP4) and German cultivars 'Lirajet' and 'Express'. AP5 and NP2, AP6 and NP3, AP7 and NP4 are sister lines from F2 ('ap-Tengbe' $x$ 'DH-Samourai'), F2 (((F7'ap-camp.' × 'Libraska') × 'Lirajet') × 'Capitol') and F2 (((F7'ap-camp.' × 'Libraska') × 'Lirajet') × 'Express'), respectively.

Randomized complete blocks were designed for the field experiments at Futterkamp and Birkenmoor in northern Germany. At both locations, the genotypes were treated with fungicide $(1.5 \mathrm{~L}$ Konker/ha) or without the fungicide in three repetitions. At Futterkamp, Sclerotias were spread artificially in winter in order to induce more infection.

Plant samples were harvested 4-6 weeks before harvest for enzyme tests. As sample, a section of plant stalk with approximately $30 \mathrm{~cm}$ in length was cut off from a plant at the position around 15 to $45 \mathrm{~cm}$ above ground surface. 30 pieces of stem sample were collected from the two inner rows of a plot. The stem samples were chopped, dried at temperature of $35-38{ }^{\circ} \mathrm{C}$ (Memmer Modal 800 ) for 5 days, and milled to fine scraps. They were then kept in fridge at -20 ${ }^{\circ} \mathrm{C}$ before used for enzyme tests.

Protease and xylanase tests were chosen for determining the ID of plant samples. The concentrations of plant abstractions were 1:70 and 1:105 for protease and xylanase tests, respectively.

Grain yield was determined at the three locations. The apetalous lines were compared with the normal petalled lines for grain yield in context of different ID.

Analysis of variance (ANOVA) was performed using the software PLABSTAT (UTZ 1994). Statistical significance was tested by appropriate F-Test. 


\section{Results}

(1) Field scoring of IR and SI for the field experiment at Hangzhou

The IR and SI scores for Sclerotinia infection are illustrated in Figure 7.4-2. The scores are the mean values of three repetitions.

In average, the apetalous lines were less infected than the partial apetalous line, while the partial apetalous line was less infected than the normal petallous lines in term of IR, which was 19,7 as mean for the apetalous lines (AP1, AP2, AP3 and AP4), contrasting to 22,3 for the partial apetalous line (HAP), and 22,7 as mean for the normal petalled lines (NP and 'ZY-758'). However, there were little differences among the three flower types for SI, which were 0.55 as mean for apetalous lines, 0.53 for the partial apetalous line and 0,54 as mean for normal petallous lines, respectively.

When the tested lines were compared as individuals, the order of IR values ranking from the least to the greatest was AP1, AP4, AP2/AP3 (same value), NP, HAP and 'ZY-758'. However, the order for SI ranking from the least to the most was AP3, AP1/NP, AP2/HAP, 'ZY-758' and AP4.

ANOVA shows that there were significant differences among the tested lines for IR, but not for SI. AP1 had significantly lower IR than all other lines. There were no significant differences among HAP, AP2, AP3, AP4 and NP1 in respect to their IR values, and 'ZY-758' was significantly higher in IR than all other tested lines.

(2) The relationship of enzymes' activities and ID

As shown in Figure 7.4-3, cellulase (a), xylanase (b) and protease (c) tests were able to distinguish the different plant materials, which had different field observed severity of Sclerotinia infection, with corresponding OD (592 nm) values, provided that appropriate concentrations of plant abstraction were given, but the result of 1,3-ß-glucanase test (d) showed hardly any reasonable relations between the OD $(592 \mathrm{~nm})$ value and the field observation with whatever a tested concentration. 


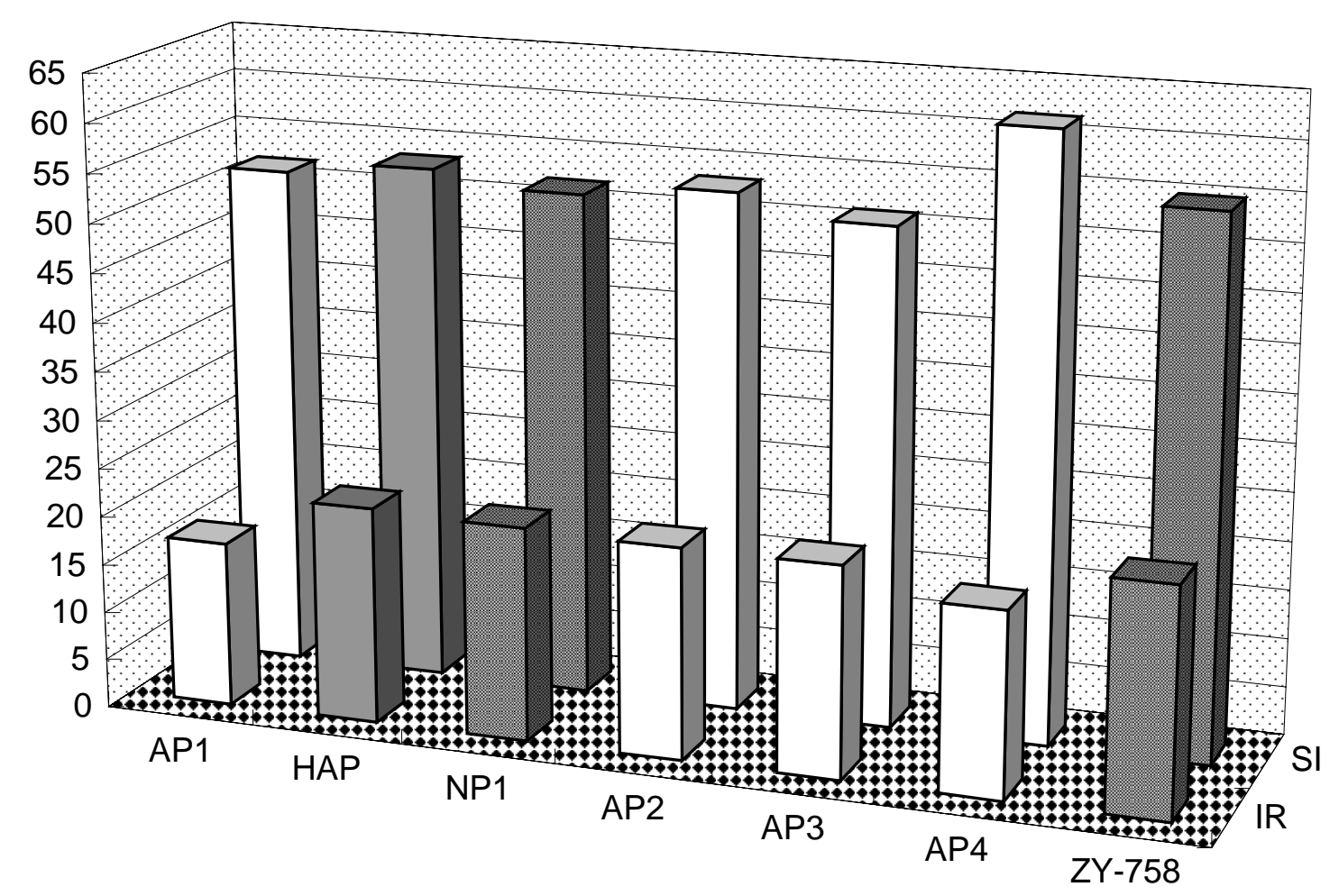

Figure 7.4-2 Scores of IR and SI from Sclerotinia infection for field experiment at Hangzhou, China 1999.

There was significant genotype effect for ID $\left(L S D_{0,05}=3.62\right)$, but not for $S I$

Black column: Gentyopes with flowers of normal petal number

White column: Genotypes with apetalous flowers

Grey column: Genotype with flowers of intermediate petal number 
In terms of wider range of $O D$ variation in responding to different severe degrees field observed, the concentrations of $1: 40,1: 60$ and 1:80 were found appropriate for cellulase, protease and xylanase tests, respectively.

The two less infected samples, lip1 and lip2, or the two infected samples ip 1 and ip2, differed from each other for OD (592 nm) values by protease, xylanase and cellulase tests, indicating the ability of the enzyme tests to distinguish plant samples that even had the same severe degrees field observed.

In general, the OD (592 $\mathrm{nm}$ ) values from cellulase, xylanase or protease tests increased in parallel responding to increasing severe degrees (from $h p$, lip, ip to hip) field observed. Nevertheless, the results of different enzyme tests did not agree with each other in determining ID of some plant samples, for example, lip2 had less OD (592 $\mathrm{nm}$ ) value than lip1 by protease test, but it had greater OD $(592 \mathrm{~nm})$ value than lip2 by xylanase and cellulase tests.

Figure 7.4-4 shows the OD $(592 \mathrm{~nm})$ values for the activities of the enzymes in responding to the increasing percentage of infected plant tissues in 1 gram of dry matter mixture. It indicates that there was positive linear relationship between the OD $(592 \mathrm{~nm})$ values and the percentage of the infected plant tissue in the mixture by protease $\left(R^{2}=0.9522\right)$ and xylanase $\left(R^{2}=0.9579\right)$ tests. However, by cellulase test, there was hardly proportional linear relationship between OD $(592 \mathrm{~nm})$ value and the percentage of the infected plant tissue in the mixture $\left(R^{2}=0.6805\right)$.

(3) Enzyme tests for ID of Sclerotinia infection in the field experiments in northern Germany

The result is given in Figure 7.4-5. The artificial supply of sclerotias in winter at Futterkamp resulted in heavier Sclerotinia infection, with average OD (592 nm) values of 0.10 and 0.22 for protease and xylanase activities, in comparison to 0.05 and 0.17 at Birkenmoor. The effect of fungicide application depended on location. At Futterkamp, the treatment without fungicide had higher OD (592 nm) values for the enzyme activities than the treatment with fungicide application. However, at Birkenmoor, the effect of fungicide was not demonstrated. 

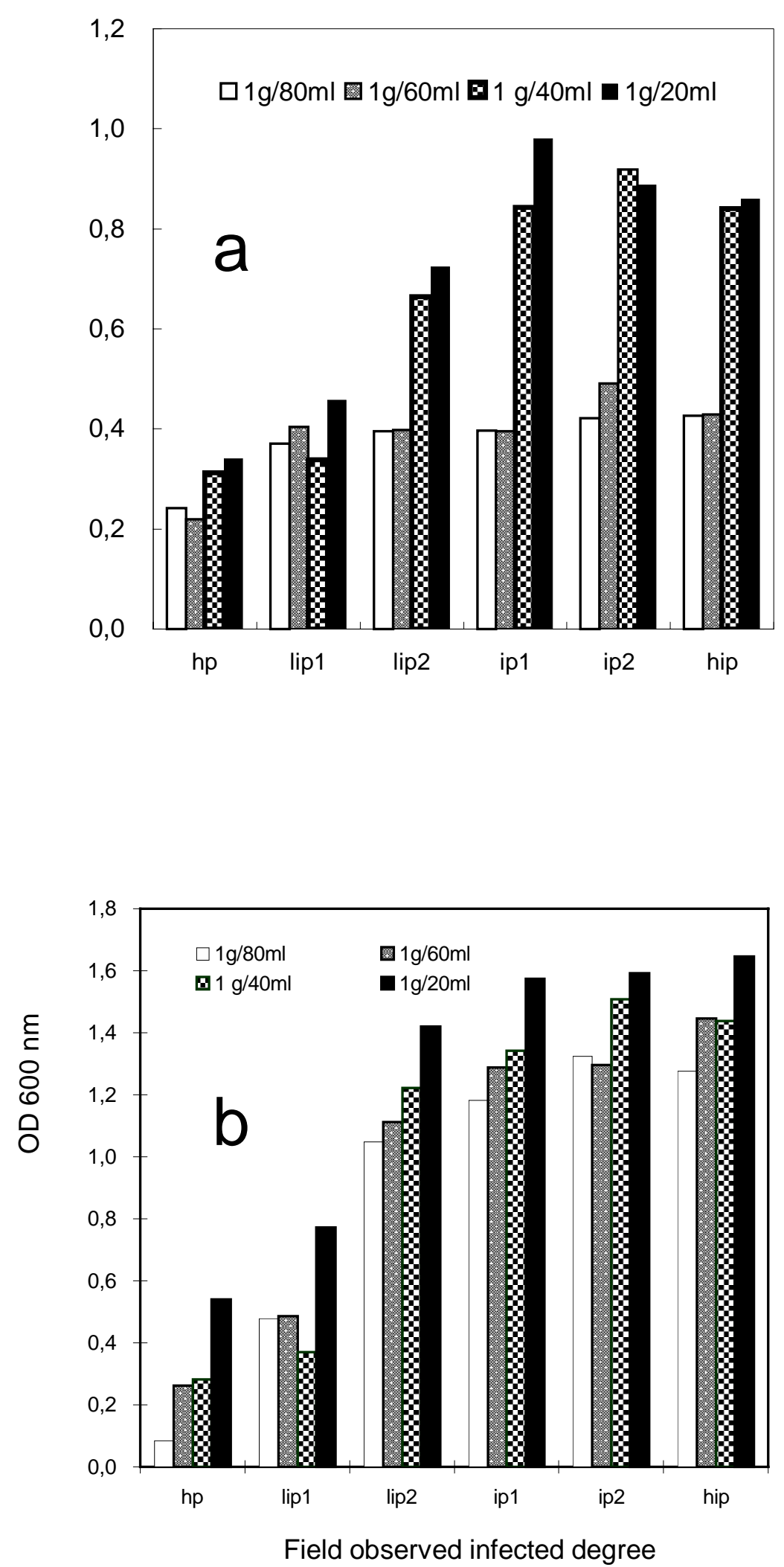

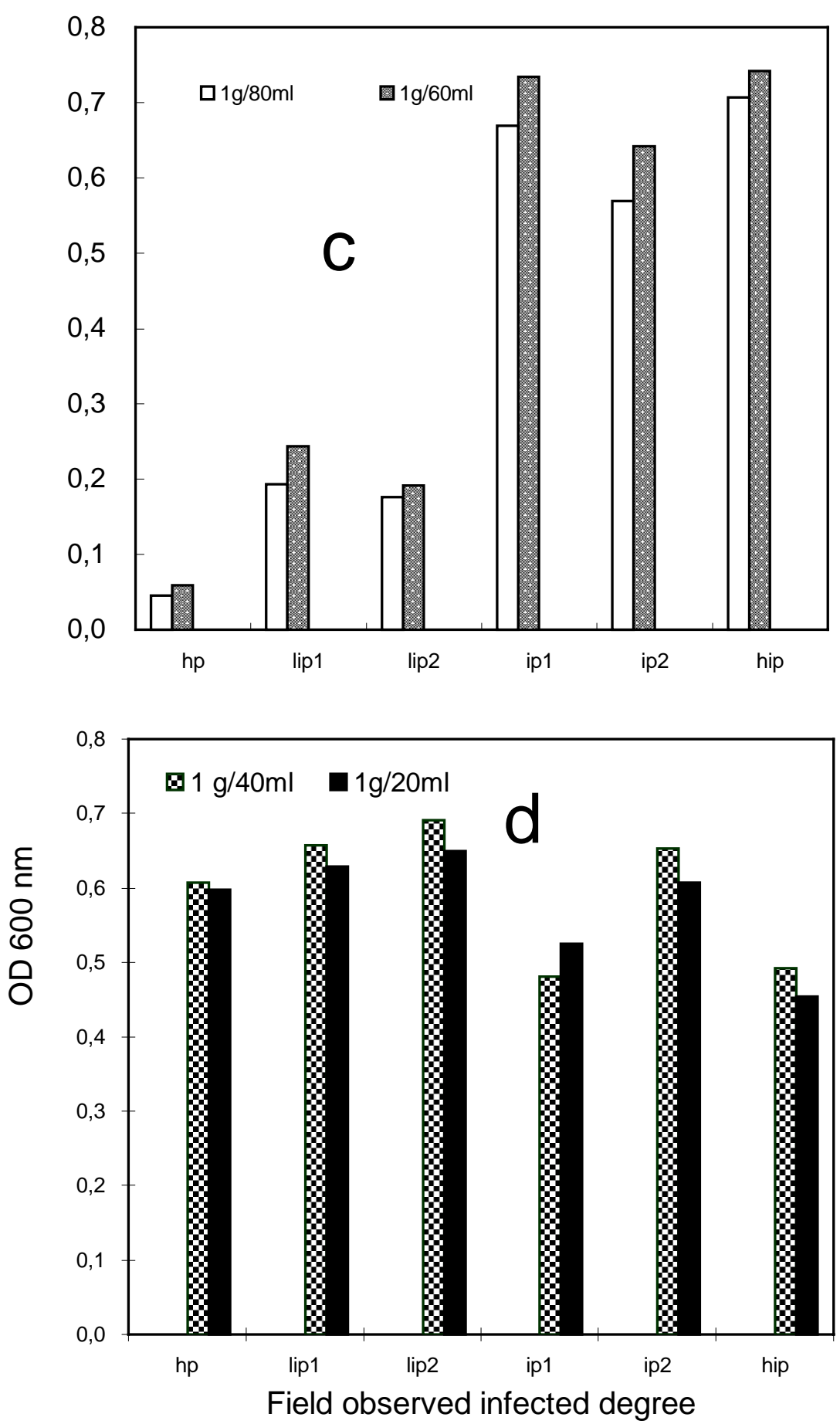

Figure 7.4-3 The relationship of field observed severity for Sclerotinia infection and the $O D$ value of enzyme tests of (a) cellulose (b) xylanse (c) protease (d) 1,3-ß-glucanase 


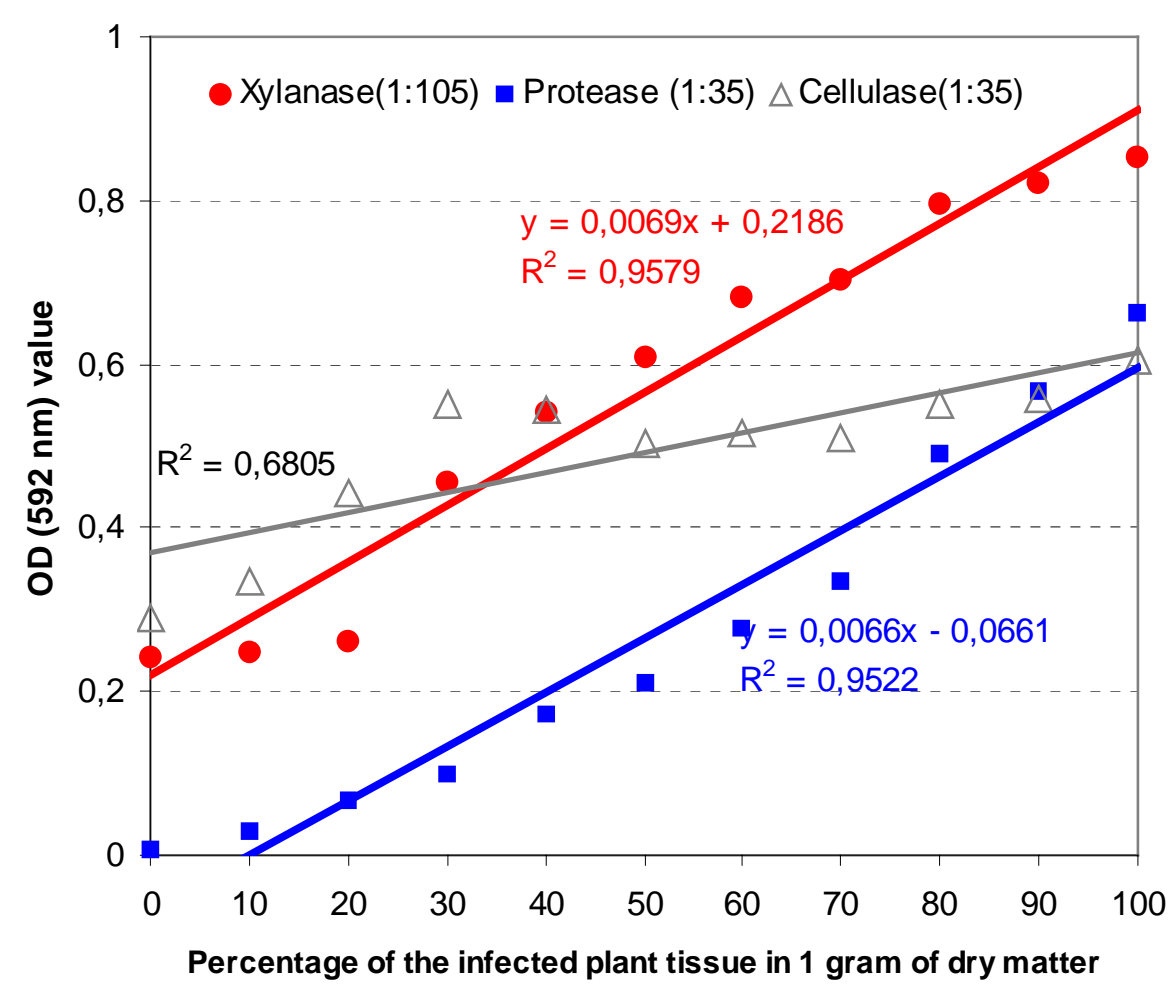

Figure 7.4-4 OD (592 $\mathrm{nm}$ ) value for enzymes' aivities in responding to the increasing percentage of the infected plant tissue in $1 \mathrm{~g}$ of dry matter

Figure 7.4-5 shows that the mean OD $(592 \mathrm{~nm})$ values for apetalous group (consisted of by AP5, AP6 and AP7) were less than that for the normal petalled group (consisted of by NP2, NP3 and NP4) under most of the conditions either by protease or by xylanase test. Exceptions were the cases with fungicide application at Birkenmoor, where, the apetalous group had almost the same OD $(592 \mathrm{~nm})$ values as the normal petalled group by either protease or xylanase test. Bigger differences of OD $(592 \mathrm{~nm})$ values between the two groups were revealed by protease test than by xylanase test. The biggest difference between the two groups was revealed by protease test where fungicide was not applied at Futterkamp. 

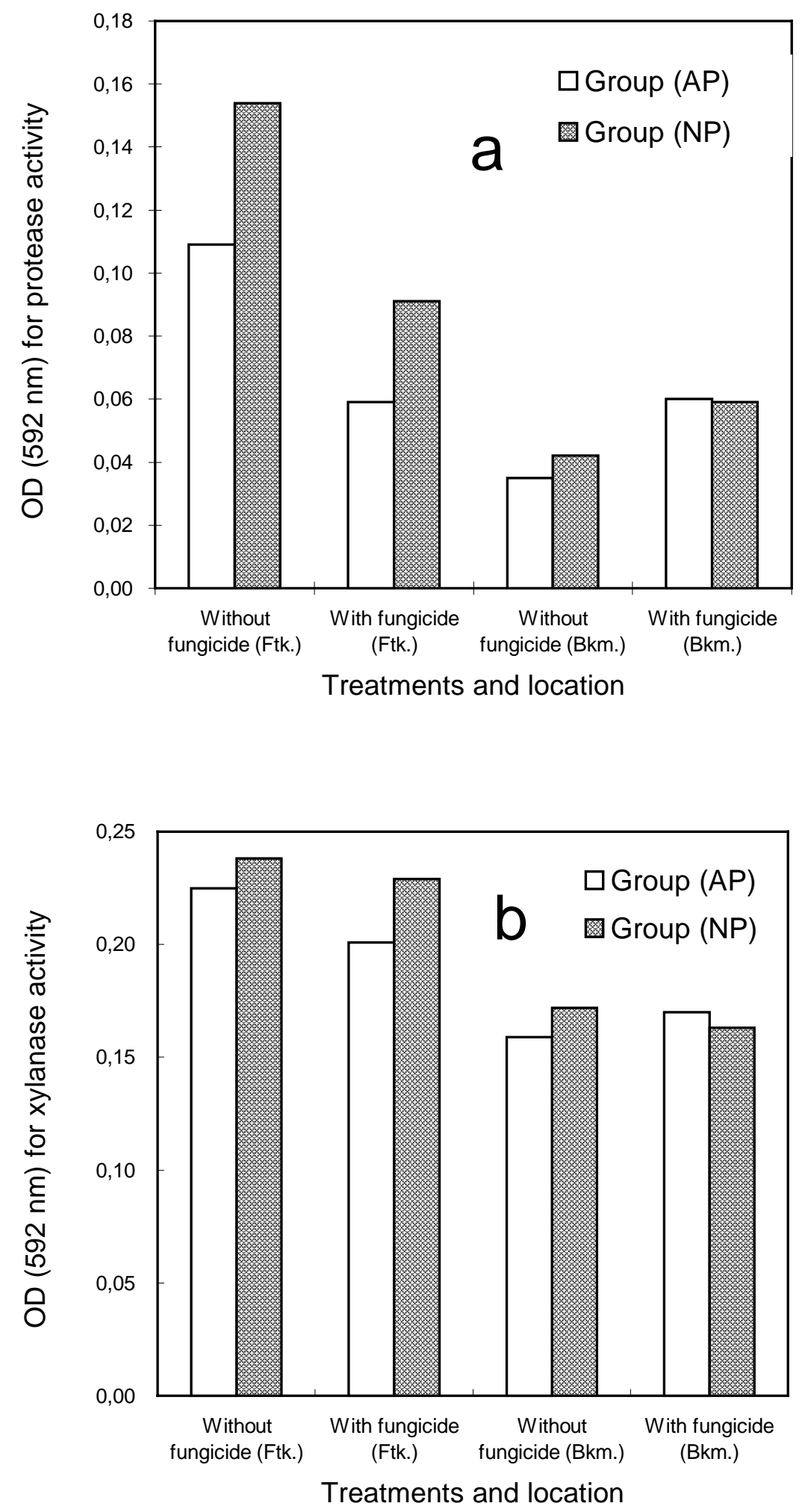

Figure 7.4-5 Comparison of the Group (AP) and the Group (NP) with or without fungicide application at Futterkamp and Birkenmoor for OD (592 nm) value of protease (a) and xylanase (b) activities 
However, in average, the apetalous group did not surpass the two German cultivars in term of less Sclerotinia infection revealed by the both enzyme tests (data not shown).

Table 7.4-1 Analysis of variance of OD (592 $\mathrm{nm})$ value for protease activity for field experiments at Futterkamp and Birkenmoor

\begin{tabular}{llllll}
\hline Source & DF & SS & MS & F & LSD5 \\
\hline Location & 1 & 0.0548 & 0.0548 & $34.86^{\star *}$ & 0.02 \\
Treatment & 1 & 0.0024 & 0.0024 & 1.55 & 0.02 \\
Genotype & 7 & 0.0276 & 0.0039 & $2.51^{\star}$ & 0.03 \\
Repl:Loc. & 4 & 0.0292 & 0.0073 & $4.65^{\star *}$ & 0.03 \\
Treat x Loc. & 1 & 0.0200 & 0.0200 & $12.72^{\star *}$ & 0.02 \\
Geno. x Loc. & 7 & 0.0244 & 0.0035 & $2.22^{\star}$ & 0.05 \\
Geno. x Treat. & 7 & 0.0161 & 0.0023 & 1.47 & 0.05 \\
Gen.xTreat.xLoc. & 7 & 0.0130 & 0.0019 & 1.18 & 0.06 \\
Gen.xRep.xTreat:Loc. & 60 & 0,0927 & 0,0016 & - & - \\
Total & 95 & 0,2803 & - & - & - \\
\hline
\end{tabular}

ANOVA shows that the effect of genotypes on OD (592 nm) value was significant by protease test (Table 7.4-1). However, it was not significant by xylanase test (data not shown). The individual tested lines were compared in Figure 7.4-6 for OD $(592 \mathrm{~nm})$ value for protease activity. AP7 had the lowest ID, even lower than the two controls, significantly lower than AP6, NP2 and NP4. AP5 had significantly lower ID than NP2; its ID did not differ significantly from that of other genotypes. There were no significant differences among AP6, NP2, NP3 and 'Lirajet' for ID. When paired comparisons were made between the sister lines, namely between AP5 and NP2, AP6 and NP3, AP7 and NP4, the apetalous type demonstrated significantly less infection than the normal petalled type in two cases (AP5 versus NP2, AP7 versus NP4). In one case (AP6 versus NP3), there was no significant difference for ID. 


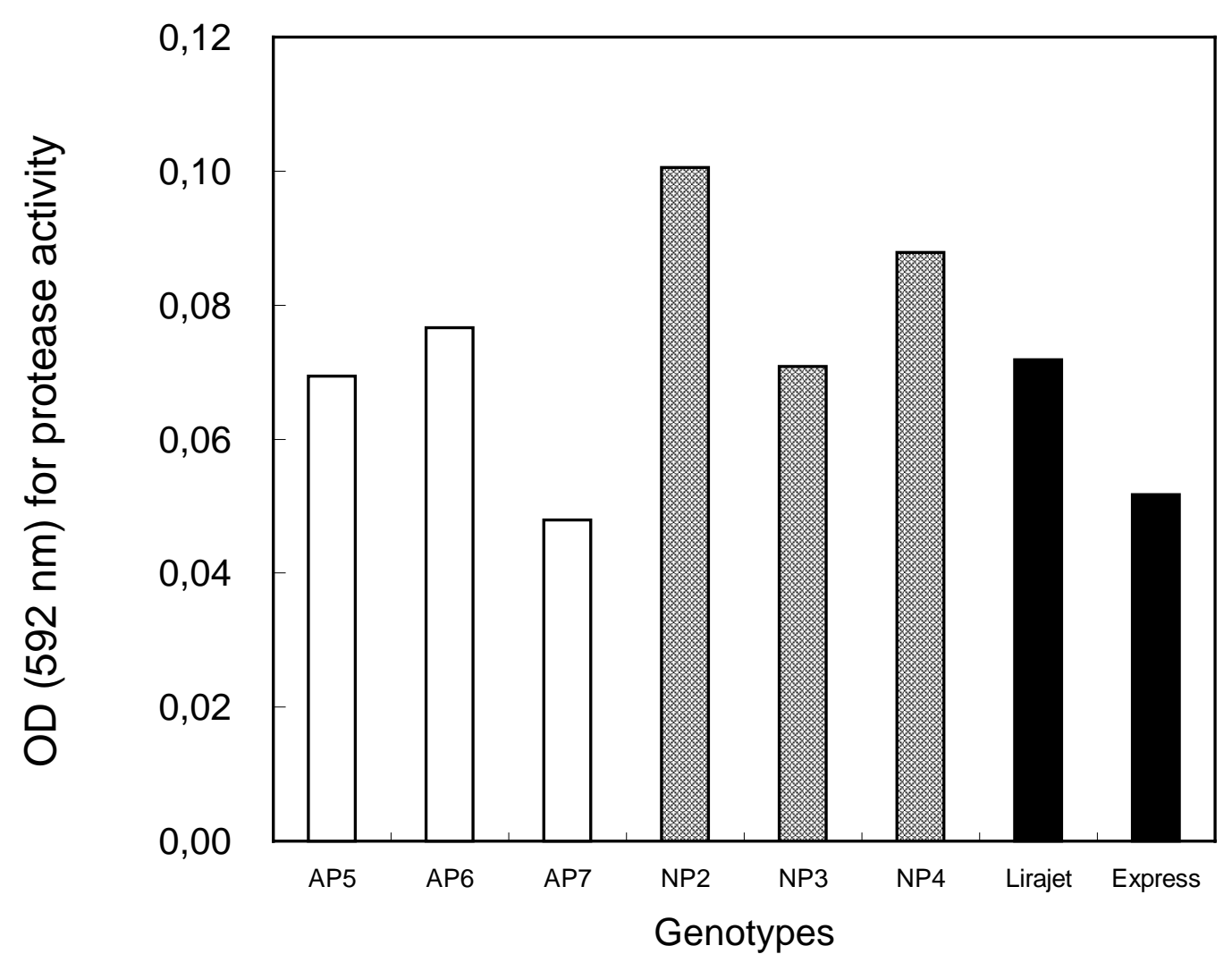

Figure 7.4-6 Mean OD (592 nm) values of two locations for protease activities indicating ID from sclerotinia disease ( $L S D 0.05=0.03$ )

(4) Grain yield of the apetalous and normal petalled lines

The grain yield of apetalous lines was compared with that of their sister lines with partial or normal petalled flowers as well as the local cultivars (Figure 7.4-7).

ANOVA revealed that at Hangzhou, there were no significant differences among the three sister lines AP1, HAP and NP1 for grain yield. 'ZY-758' was significantly higher in yield than any other tested lines. AP4, which had the second least IR of Sclerotinia, was higher in yield than all the rest except for the control. AP1 had not significantly better yield, although it was significantly lower in IR than other lines. There were no significant differences among AP1, HAP, NP, AP2, AP3 for yield (Figure 7.4-7a). 

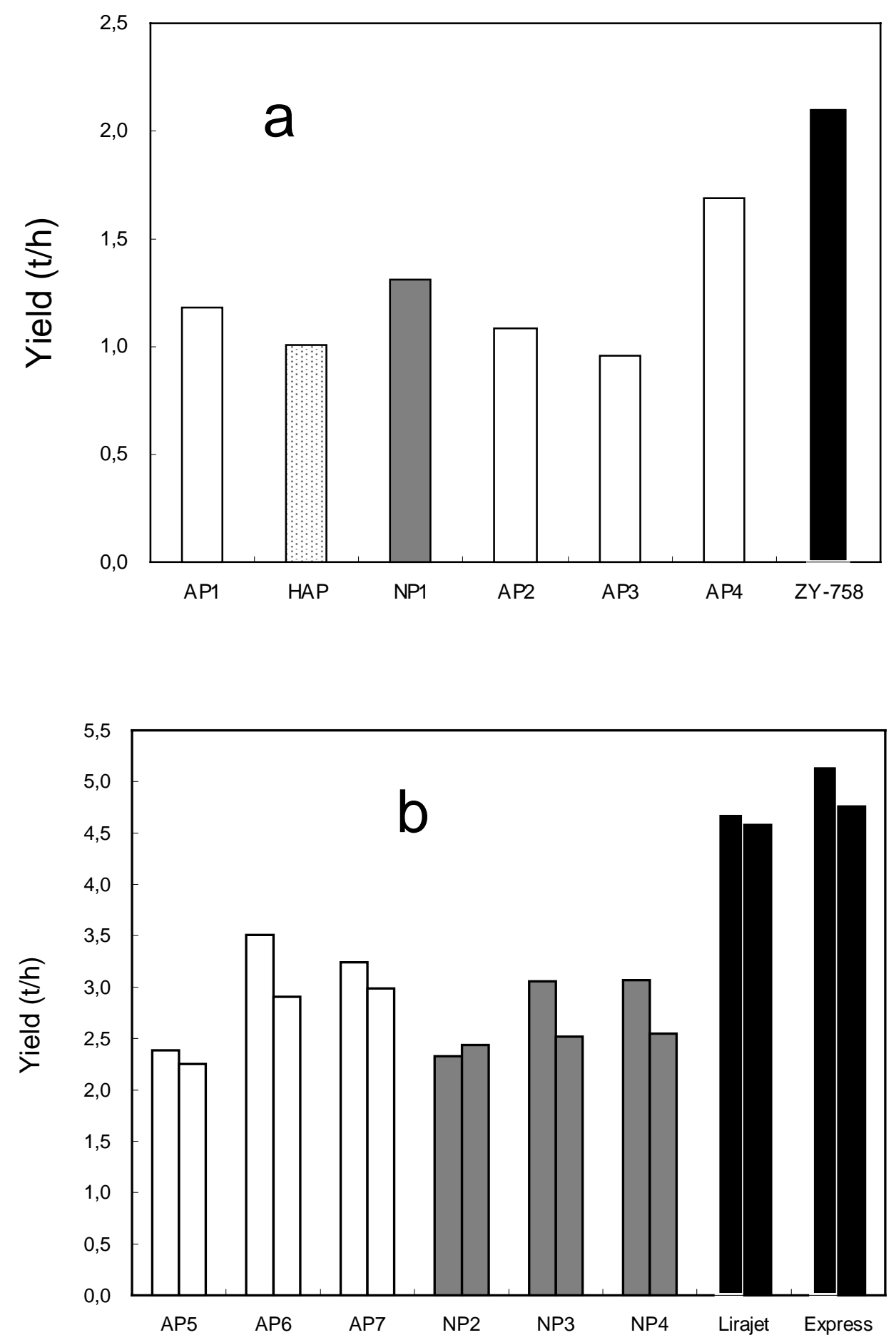

Figure 7.4-7 Comparison of the apetalous and normal petalous genotypes for grain yield at Hangzhou (a), Futterkamp (left column) and Birkenmoor (right column) (b). LSD0,05 values were 0,307, 0,363 and 0,442 for significant difference between genotypes at Hangzhou, Futterkamp and Birkenmoor, respectively 
At Futterkamp and Birkenmoor, all tested lines had significantly lower yield than 'Lirajet' and 'Express', the two German cultivars. The apetalous lines had better yield than the normal petalled lines. By paired comparison of the sister lines, AP5 with NP2, AP6 with NP3, AP7 with NP4, the apetalous type demonstrated higher grain yield in two cases (AP6 versus NP3, AP7 versus NP4). Significant difference was, however, found only between the sister lines AP6 and NP3 (Figure 7.4-7b).

\section{Discussions}

(1) The field experiment at Hangzhou

Only one of the tested apetalous lines (AP1) was found significantly less infected from Sclerotinia disease than the normal petalled lines, including the Chinese cultivar 'ZY-758'. The other apetalous lines (AP2, AP3 and AP4) did not have significantly better performance than the normal or partial apetalous lines. It may be due to the following reasons.

First, according to field observation, AP1 was the breeding line with apetalous flowers of the purest, while the other apetalous lines, in particular AP2 and AP3, had flowers with some petals in the local environment.

Second, it is normally windy during flowering season (mid-March to end-April) at Hangzhou, the wilt petals on the plants with normal flowers could have been dispersed and carried by the wind. They could land on leaves or other parts of the apetalous plants, which could lose, at least to some extent, their advantage of less infection. If more than four rows were planted in each plot and only the plants in most inner rows would have been investigated, the interaction between the apetalous and normal petalled lines could have been minimized.

Among the tested lines, AP1, HAP and NP1 were sister lines, which were similar in most agronomic traits except for petal number. Petals effect on Sclerotinia infection could be better revealed by the comparisons among the sister lines.

(2) The enzymatic method for ID of Sclerotinia disease

The pathogens of fungicidal diseases excrete enzymes degrading plant cell 
wall in great deal when they enter the plant or develop themselves inter the plant cells (Bateman \& Basham 1976). Afshari-Azad (1992), Holtschulte et al. (1992) Cernusco (1996) and Volke (1999) established correlations between the production of cell wall degrading enzymes and the infection of the fungicidal diseases as Pseudocercosporella herporrichoides, Fusarium culmorum, Rhizoctonia cerealis, Verticillium dahliae and Leptosphaeria maculans. We tried in the experiment to find out if such correlation would be established in the system B. napus / S. sclerotinia. Positive linear correlations were established between ID of Sclerotinia disease and xylanase or protease activities. Compared with field scoring, it is a biochemical method that describes Sclerotinia infection quantitatively and is more independent on personal experience in determining the infection degree. Moreover, it may distinguish the infection that seems identical to eyes. The limit of this method is that it is not pathogen specific. The production of the cell wall degrading enzymes in plant cell, in this case protease or xylanase, might have been partially contributed by the activities of other pathogens, e.g. Verticillium dahliae, Peronospora paraistica, Botrytis cinerea. That could be the reason why lip2 had less OD (592 $\mathrm{nm}$ ) value than lip 1 by protease test, but it had greater OD (592 $\mathrm{nm}$ ) value than lip2 by xylanase and cellulase tests. lip1 and lip2 might be infected by more than one pathogen and different pathogens would produce certain enzyme in different intensity.

In order to reduce the probability of such cross-reacting, the section of plant stalk with approximately $30 \mathrm{~cm}$ in length was cut off from a plant at the position around 15 to $45 \mathrm{~cm}$ above ground surface, where typical symptom of Sclerotinia infection occurs and the activity of the pathogen may prevail. However, the possibility of the infection from other pathogens could not be excluded. We will investigate the correlation between this method and the more specific and sensitive immunological method as Enzyme Linked Immunosorbent Assay (ELISA) in a separate paper.

(3) The field experiments at Futterkamp and Birkenmoor

The result shows convincing advantage of the apetalous lines in comparison to their normal petalled sister lines in terms of lower ID of Sclerotinia disease. However, when the apetalous lines were compared with the two German 
cultivars, especially 'Express', they demonstrated hardly any advantages. To understand this, one should realize that the infection of disease is determined by many factors, including the maturity of a certain genotype. In this experiment, 'Express' and 'Lirajet' were earlier get flowering than all the tested apetalous lines. There existed the possibility that the press from the disease might be less at earlier stage than later stage and the apetalous line might suffer from heavier press from the disease when they were starting flowering.

Petal's role in distributing disease may not limit only for Sclerotinia sclerotiorum. The spores of some pathogens, e.g. Botrytis cinierea (Jamaux 1994) and Peronospora parasitica (Lü \& Fu 1990), which causes symptoms during or shortly after flowering, were also found on petals. Lefol \& Morrall (1999) even discovered more than 50 groups of ascospores existing on rape petals, among which some are aggressive. Genotypes with apetalous flowers might have the advantage to avoid these diseases also.

Inclusion, the influence of apetalous flowers on less Sclerotinia infection is optimistic. Apetalous trait is worthwhile to be integrated into breeding materials of oilseed rape in order to attain lower infection from Sclerotinia.

\section{Acknowledgement}

The authors thank Dr. W. Sauermann and Mr. H. Lindenberg for the arrangement of the field experiments at Futterkamp and Birkenmoor in Schleswig-Holstein of northern Germany, Ms. S. Rummelsberger and Ms. N. Ritgen for assisting in harvesting of the plant samples. The financial supports from Prof. Werner Schultze Stiftung and Forschungs- und Entwicklungsfond Raps for the first author are gratefully acknowledged.

\section{Reference}

Afshari-Azad H, 1992. Produktion extracellulärer, hydrolytischer Enzyme von Pseudocerco-sporella herporella herpotrichoides (Fron) Deighton, Fusarium culmorum (W.G.SM) SACC sowie Rhizoctonia cerealis in vitro bzw. in planta und ihre Beziehung zur Pathogenese. Diss., Universität Göttingen 
Bateman D F and Basham H G, 1976. Degradation of plant cells and membranes by microbial enzymes. In: R. Heitefuss and Williams (Eds.): Physiological Plant Pathology. Springer Verlag, Berlin-Heidelberg-New York: 316-345

Bateman D F, Jones T M and Yoder O C, 1973. Degradation of corn cell walls by extracellulars enzymes produced by helminthosporium maydis race $\mathrm{T}$. Phytopathology 63: 1523-1529

Cerunsco R, 1996. Entwicklung und Erprobung enzymatischer und immunologischer Nachweismethoden für Verticillium dahliae kleb. im raps (Brassica napus L) Dissertation, Universität Göttingen

Cooper R M and Wood R K S, 1975. Regulation of synthesis of cell wall degrading enzymes by Verticillium albo-atrum and Fusarium oxysporum f. sp. Lycopersici. Physiol. Plant Pathol. 5: 135-156

Fang J and Platford R G, 1994 Distribution, prevalence and incidence of canola diseases in Manitoba. Canadian Plant Disease Survey 75: 145-147

Heitefuss R, König K, Obst A and Rescheke M, 1987. Weißstengeligkeit. Pflanzenkrankheiten und Schädlinge im Ackerbau. pp : 88-89

Holtschulte B 1992. Untersuchungen zur Biologie und Bedeutung von Verticillium dahliae kleb. Und Leptosphaeria maculans (Desm.) Ces. Et Not. (Anamorph: phoma lingam (Tode ex Fr.)) innerhalb des Erregerkomplexes der krankhaften Abreife von Raps. Dissertation, Universiät Göttingen.

Jamaux D I, Spire D, 1999. Comparison of responses of ascospores and mycelium by ELISA with anti-mycelium and anti-ascospore antisera for the development of a method to detect Sclerotinia sclerotiorum on petals of oilseed rape. Annals of Applied Biology 134: 171-179 
Jamaux I, Gelie B, Lamarque C, 1994. Early stages of infection of rapeseed petals and leaves by Sclerotinia sclerotiorum revealed by scanning electron microscopy.

Jiang L X, Yu J B, Jin M S and Jiang W L, 1995. Evaluation of resistance to Sclerotinia sclerotiorum and TuMV virus for 140 land races (B. napus) in Zhejiang, Acta Agricult. Zhejiangensis 7 (3): 202-205

Kharbanda P D and Tewari J P, 1996. Integrated management of canola diseases using cultural methods. Canadian Journal of Plant Pathology 18: 168-175

Krüger W, 1975: Die Beeinflussung der Apothezien- und AscosporenEntwicklung des Rapskrebserregers Sclerotinia sclerotiorum (Lib.) de Bary durch Umseltfaktoren. Pfl. Krankh. 2, 101-108

Larmarque C, 1983. Conditions climatiques qui favorisent le processus naturei de ia contamination du colza par le Sclerotinia sclerotiorum. Proc. $6^{\text {th }}$ International Congress Paris France: 957-962

Lefol C, Morrall R A A, 1996. Immunofluorescent staining of sclerotinia ascospores on canola petals. Canadian Journal of Plant Pathology 18: 237-241

Lü Z J and Fu S Z , 1990. Inheritance of apetalous character in Rape (Brassica napus L.) and its implication in breeding. Jiangsu J. Agricult. Sci. 6: 30-36

Mc Lean D M, 1958: Role of dead flower parts in infection of certain crucifers by Sclerotinia sclerotiorum (Lib.) De. Bary. Plant Disease Rep. 42, 663-666

Newmann P L and Bailey D J, 1987. Screening for resistance to sclerotinia sclerotiorum in oilseed rape in the glasshouse. Ann. Appl. Biol. 110: 150-151 
Paul V H, 1991. Pilzkrankheiten in Raps und deren Bekämpfung. In: Paul V H (ed.): Der Raps. DowElanco. pp : 123-141

Perez A E and Tena M, 1990. Purification and characterization of pectic enzymes from two races of Fusarium oxysporum f. sp. ciceri differing in virulence to chickpea (Cicer arietium L.) Phys. Mol. Plant Pathol. 37: 107-124

Singh R and Tripathi N N, 1994. Assured method of inoculation and screening of Brassica spp. against Sclerotinia sclerotiorum (Lib) De Bary. Crop Research (Hisar) 8: 570-574

Thomson J R, Kaminski D A, Morrall R A A and Gugel R K, 1994. Survey of canola diseases in Saskatchewan. Canadian Plant Disease Survey 75: $137-141$

Twengstrom E, Kopmans E, Sigvald R and Svensson C, 1998. Influence of different irrigation regimes on carpogenic germination of sclerotia of Sclerotinia sclerotiorum. J. Phytopathology 146: 10, 487-493

Volke B, 1999. Leptosphaeria maculans, der Erreger der Wurzelhals-und Stengelfäule an Raps: Verbreitung verschiedner Pathogenitätsgruppen in Europa, Quantizierung des Befalls und Schadwirkung im Freiland Dissertation, Universität Göttingen.

Wahmhoff W, Hedke K, v Tiedemann A, Nitzsche O and Ulber B, 1998. Impact of crop rotation and soil cultivation on the development of pests and diseases of rapeseed Zeitschrift fü $r$ Pflanzenkrankheiten und Pflanzenschutz 106: 57-73

Wirth $S \mathrm{~J}$ and Wolf $\mathrm{G} \mathrm{A}, 1990$. Dye-labled substrates for the assay and detection of chitinase and iysozyme activity. J. Microbiol. Methods 12: 197-205

Zhou L C, 1994. Evaluation of rapeseed genotypes against sclerotinia sclerotiorum (Lib.) De Bary. Oil Crops of China. 94: 69-72 


\section{ZUSAMMENFASSUNG}

\section{Untersuchungen an einer blütenblattlosen Mutante bei Raps (Brassica napus): Vererbungsweise und Einfluß auf Ertragsphysiologie und Krankheitsanfälligkeit}

Blütenblattlose Genotypen könnten für die Rapszüchtung von Bedeutung sein, da von ihnen eine leistungsfähigeren Photosynthese, eine bessere Assimilatnutzung sowie eine geringere Anfälligkeit gegenüber Krankheiten, die über die Blütenblätter verbreitet werden, zu erwarten ist. Im Rahmen dieser Doktorarbeit wurden die blütenblattlose Mutante 'ap-Tengbe' und ihre Kreuzungsnachkommenschaften auf (1) die Vererbung der blütenblattlosen Eigenschaft, (2) den Einfluss von Umweltfaktoren, insbesondere den Effekt von Phytohormonen, (3) die Ertragsphysiologie und (4) die Infektionsanfälligkeit gegenüber dem Krankheitserreger Sclerotinia sclerotiorum untersucht.

Die Sorte 'Falcon' wurde mit 'ap-Tengbe' gekreuzt. Die F1, beide Rückkreuzungsgenerationen und ihre reziproken Kreuzungen sowie die F2 wurden in Feldversuchen in Göttingen, 1998 und in Hangzhou, China 1999 angebaut. Die reziproke F2 Population wurde nur in Hangzhou beobachtet.

Weiterhin wurden Veränderungen in der Ausprägung der Blütenblattlosigkeit im Verlauf der Blühperiode an den beiden Versuchsstandorten erfasst. Außerdem wurden einige doppelhaploide (DH) Linien mit blütenblattlosen, halb blütenblattlosen oder normalen Blüten vor Blühbeginn mit Auxinen oder Cytokininen behandelt und die Auswirkung dieser Hormone auf die Blütenblattbildung wurde beobachtet.

Die Ertragsphysiologie einer genetisch blütenblattlosen Linie wurde verglichen mit einer halb blütenblattlosen und einer normalen Geschwisterlinie. Dazu wurden Feldversuche mit drei Bestandesdichten und drei Stickstoffstufen an zwei Orten in Norddeutschland durchgeführt.

Die Infektionsrate (IR) und die Stärke des Befalls mit Sclerotinia sclerotiorum (SI) wurden in Hangzhou 1999 an vier blütenblattlosen Linien, einer halb blütenblattlosen Linie und zwei normalen Linien bonitiert. Zusätzlich wurden drei weitere blütenblattlose Linien und ihre Geschwisterlinien mit normaler Blütenbildung, sowie zwei Verleichssorten an zwei Orten in Norddeutschland angebaut. Verschiedene Enzym-Tests wurden hinsichtlich ihrer Eignung zur quantitativen Feststellung der Befallsstärke verglichen. Infektionsgrad (ID) der Rapsstengelproben wurden durch 
Protease- und Xylanase-Tests analysiert.

Die Ergebnisse zeigten, dass

- die Blütenblattlosigkeit in der Mutant 'ap-Tengbe' von der Interaktion zwischen cytoplasmatischen Genen und zwei Paaren von Kerngenen geregelt wird. Vollständig blütenblattlose Blüten werden nur bei Genotypen mit ' $a p$ ' Cytoplasma und zwei homozygot rezessiven Genen $\left(p_{1} p_{1} p_{2} p_{2}\right)$ ausgebildet.

- Die Anzahl der Blütenblätter je Blüte verringert sich von Beginn der Blühperiode bis zum Blühende in Nachkommenschaften mit Genen für Blütenblattlosigkeit. Diese Reduktion der Blütenblattbildung wird wahrscheinlich durch endogene Anreicherung der Auxine oder/und der Cytokinine während der Blühperiode verursacht.

- Blütenblätter reduzieren die Lichteinstrahlung besonders auf die oberen Laubblätter stark. Dies führt zu einem geringeren Blattflächenindex (LAI), einer kürzeren Lebensdauer photosynthetisch aktiver Blätter und einer Verringerung der Gesamttrockenmasse. Öl- und Proteingehalt der Samen werden durch die Blütenblätter jedoch nicht beeinflusst. Ein zu erwartender Ertragsvorteil der blütenblattlosen Genotypen hängt von der genetischen Herkunft der Eigenschaft Blütenblattlosigkeit $a b$. Bei blütenblattlosen Linien mit dem genetischen Hintergrund 'ap-Tengbe' wurde sogar eine Ertragsminderung festgestellt, die mit einer verringerten Pollenproduktion zu erklären ist.

- Blütenblattlose Linien werden im Vergleich mit ihren normalen Geschwisterlinien weniger von Sclerotinia befallen. Die Messung der Protease- sowie der Xylanase-Aktivität in Pflanzenextrakten ist geeignet, den Infektionsgrad (ID) mit Sclerotinia sclerotiorum quantitativ zu ermitteln.

Die Mutante 'ap-Tengbe' kann erfolgreich genutzt werden, um vollständig blütenblättlose Linien zu entwickeln, wobei jedoch cytoplasmatische Effekte berücksichtigt werden müssen. Blütenblattlose Linien könnten grundsätzlich zu höhern Kornerträgen und einer geringern Anfälligkeit genen Sclerotinia führen. Für eine zukünftige züchterische Nutzung der blütenblattlosen Mutante 'ap-Tengbe' sollte versucht werden, die genetische Kopplung der Blütenblattlosigkeit mit einer reduzierten Pollenproduktion zu durchbrechen. 


\section{LIST OF TABLES AND FIGURES}

(13 tables and 18 figures)

Table 1-1 Worldwide production of the most important oilseeds (1996-1999)

Table 1-2 Different apetalous sources in oilseed Brassicas and the inheritance of the apetalous trait in these sources

Table 7.1-1 Distribution (\% of total of plants) for Petalous Degree (PDgr) in two environments

Table 7.1-2 Genetic interpretation for apetalous, partial apetalous and normal petalled phenotypes

Table 7.1-3 Chi-Square test $\left(\chi^{2}\right)$ for segregation of Petalous Degree (PDgr) in segregating populations grown at Göttingen or Hangzhou

Table 7.2-1 ANOVA of paired PDgr data scored on same plant at initial anthesis and end flowering stages in two environments

Table 7.2-2 Effect of the hormones on reduction of PDgr on the racemes affected by hormone application (R1) (\%)

Table 7.2-3 Effect of the hormones on reduction of PDgr of whole plants (R2) $(\%)$

Table 7.2-4 Effect of the hormones on number of affected racemes with PDgr changing (N1)

Table 7.3-1 Weight of floral organs $(\mathrm{mg})$ of the apetalous (AP), half apetalous (HAP) and normal petalled (NP) lines at Reinshof 1998

Table 7.3-2 Correlation coefficients among floral organs, Reinshof 1998

Table 7.3-3 Mean seed yield (t/ha) of the apetalous (AP), half apetalous (HAP) and normal petalled (NP) lines, Reinshof and Teendorf 1998

Table 7.4-1 Analysis of variance of OD (592 nm) value for protease activity for field experiments at Futterkamp and Birkenmoor

Figure 2-1 The life cycle of Sclerotinia sclerotiorum

Figure 3-1 Materials used in the experiments

Figure 3-2 The process of microspore culture and development of $\mathrm{DH}$ lines

Figure 7.2-1 A typical affected raceme after application of the hormones

Figure 7.3-1 Photosynthetically active radiation (PAR) absorption at initial and peak flowering measured on ground surface, Reinshof 1998, respectively, with least significant difference (LSD) for $P=0.05$

Figure 7.3-2 Photosynthetically active radiation (PAR) absorption at peak flowering measured at base of flower layer in low (N0D30), 
normal (N100D80) and high (N200D120) nitrogen and plant density levels, Reinshof 1998

Figure 7.3-3 Mean leaf area index (LAl) at various combinations of genotype $(G)$, nitrogen level $(N)$ and plant density (D) before anthesis (a), at peak flowering (b) and after flowering (c), Reinshof 1998

Figure 7.3-4 Mean leaf area index (LAl) at different developmental stages, Reinshof 1998

Figure 7.3-5 Mean weight of total biomass at various combinations of genotype (G), nitrogen level (N) and plant density (D), Reinshof 1998

Figure 7.3-6 Mean harvest index $(\mathrm{HI})$ at various combinations of genotype $(G)$, nitrogen level (N) and plant density (D), Reinshof 1998

Figure 7.3-7 Mean grain yield at various combinations of genotype $(G)$, nitrogen level $(\mathrm{N})$ and plant density (D), Reinshof and Teendorf, 1998

Figure 7.4-1 Micro colored plate

Figure 7.4-2 Scoring of IR and SI from Sclerotinia infection for field experiment at Hangzhou, China 1999. ( $\mathrm{LSD}_{0,05}=3.62$ for significance of IR among genotypes)

Figure 7.4-3 The relationship of field observed degree for Sclerotinia infection and the OD value for enzyme tests of (a) cellulose (b) xylanse (c) protease (d) glatinase in plant tissues

Figure 7.4-4 OD (592 $\mathrm{nm}$ ) value for enzymes' aivities in responding to the increasing percentage of the infected plant tissue in $1 \mathrm{~g}$ of dry matter

Figure 7.4-5 Comparison of the Group (AP) and the Group (NP) with or without fungicide application at Futterkamp and Birkenmoor for OD (592 nm) value of protease (a) and xylanase (b) activities

Figure 7.4-6 Mean OD (592 nm) values of two locations for severe degree of the genotypes revealed by protease test (LSD0.05 $=0.03$ )

Figure 7.4-7 Comparison of the apetalous and normal petalous genotypes for grain yield at Hangzhou 


\section{FREQUENTLY USED ABBREVIATIONS}

$\begin{array}{ll}\text { ANOVA } & \text { Analysis of variance } \\ a p & \text { The apetalous line } \\ a p-T e n g b e & \text { The Tengbe apetalous mutant } \\ C_{a p} & \text { Cytoplasm coding apetalous flowers } \\ C_{N} & \text { Cytoplasm coding normal flowers } \\ D & \text { Plant population density } \\ D H \text { line } & \text { Double haploid line } \\ F & \text { Falcon } \\ G & \text { Genotype } \\ H A P & \text { Half apetalous line } \\ H I & \text { Harvest index } \\ h i p & \text { Heavily infected plants } \\ h p & \text { healthy plant } \\ i p & \text { Infected plants } \\ i & \text { The genotypes with intermediate apetalous flowers } \\ I D & \text { Infection degree } \\ I R & \text { Infected rate } \\ L A I & \text { Leaf area index } \\ L I & \text { Light intensity } \\ \text { lip } & \text { Less infected plant } \\ N & \text { Nitrogen } \\ N A R P C & \text { Number of affected racemes with PDgr Changes } \\ N P & \text { Normal petalled genotype } \\ O D & \text { Optical density } \\ P A R & \text { Photosynthetically active radiation with wavelength of 400-700 } \\ P D g r & \text { nm } \\ P L A B S T A T & \text { Petalous degree, defined in 2.1 } \\ R B B & \text { Computer statistic program for plant breeding experiments } \\ S I & \text { Remazol Brilliant Blue } \\ & \end{array}$




\section{ACKNOWLEDGEMENT}

I would hereby express my heartfelt thanks and appreciation to Prof. Dr. Heiko $C$. Becker, my major advisor, for the time and advices that he has given during my work and in preparation of the manuscripts. My study would not have been completed without his good care in terms of both academic advice and financial support. I hope that my future academic work will be a reflection of his standard of quality and thoroughness.

My sincere thanks due also to Prof. G. Röbbelen and Dr. D. Stelling, for the developing and providing the 'ap-Tengbe' material; to Dr. C. Möllers for teaching the technique of microspore culture and DH plants development; and Dr. K. Schmidtke and Dr. H. Kimpel-Freund for teaching to use the Delta-T Logger for measurement of solar radiation; to Prof. G. Wolf and Qinghua Zhao, Institute of Plant Pathology and Protection, for advising enzyme tests for Sclerotinia infection; to Dr. J. Koch, Semundo, Dr. W. Sauermann, Lehr- und Versuchsanstalt für Landwirtschaft Futterkamp, Mr. H. Lindenberg, Amt für ländliche Räume Kiel, Ms. D. Zhang, Institute of Crop Science, Zhejiang Academy of Agricultural Sciences at Hangzhou China, for providing the possibility for field trials, to Ms. S. Rummelsberger, Ms. N. Ritgen and Mr. G. Miotke for technical assistance in greenhouse as well as in fields.

I am very much indebted to Andreas Henn for his kindness to Chinese students and visitors, as well as for his a lot of helps in greenhouse.

The financial supports to my study in Germany from German Academic Exchange Services (DAAD), Prof. Werner schultze Stiftung and Forschungs- und Entwicklungsfond Raps are gratefully acknowledged. 


\section{LEBENSLAUF}

Personalien

Lixi Jiang

geboren am 18.9.1964 in Zhejiang, China

verheiratet, ein Kind

Ausbildung

1972-1978

Grundschule Quan-Feng, Hangzhou

1978-1980

Mittelschule Nr. 8 der Stadt Hangzhou (untere

Stufe der Mittelschule)

$1980-1982$

Mittelschule Nr. 1 der Stadt Hangzhou (obere Stufe

der Mittelschule)

$1982-1986$

Fachrichtung: Pflanzenwissenschaft

Zhejiang Agricultural University at Hangzhou*

Abschluß: Bachelor of Agricultural Sciences

1996-1998

Fachrichtung: Pflanzenproduktion

Aufbaustudium Agrarwissenschaft,

Georg-August-Universität Göttingen

Abschluß: Magister Agrarwissenschaft

1998-2001

Promotionstudium am Institut Pflanzenbau und

Pflanzenzüchtung der Georg-August Universität

Göttingen

Wissenschaftliche

Mitarbeit

1986-1995

Institute of Crop Science, Zhejiang Academy of Agricultural Sciences (ZAAS) at Hangzhou

1991

Als Praktikant bei Norddeutscher Pflanzenzucht Hans-Georg-Lembke

\footnotetext{
* renamed as "College of Agricultural Sciences and Biotechnology, Zhejiang University" since 1997
} 